\title{
PRODUÇÃO E QUALIDADE DO ÓLEO ESSENCIAL DE DUAS ESPÉCIES DE MENTA CULTIVADAS EM SOLUÇÕES NUTRITIVAS
}

\section{NILSON BORLINA MAIA}

Engenheiro Agrônomo

\author{
Orientador: Prof. Dr. QUIRINO A. C. CARMELLO
}

\begin{abstract}
Tese apresentada à Escola Superior de Agricultura "Luiz de Queiroz", Universidade de São Paulo, para obtenção do Título de Doutor em Agronomia, Área de concentração: Solos e Nutrição de Plantas.
\end{abstract}

PIRACICABA

Estado de São Paulo - Brasil

Abril - 1998 
Dados Internacionais de Catalogação na Publicação (CIP) DIVISĀO DE BIBLIOTECA E DOCUMENTAÇĀO - Campus "Luiz de Queiroz"/USP

Maia, Nilson Borlina

Produçāo e qualidade do óleo essencial de duas espécies de menta cultivadas em soluçōes nutritivas / Nilson Borlina Maia. - Piracicaba, 1998.

105 p. : il.

Tese (doutorado) - Escola Superior de Agricultura Luiz de Queiroz, 1998.

Bibliografia.

1. Óleo essencial de menta 2. Produçāo agrícola 3. Qualidade 4. Soluçāo nutritiva I. Titulo

CDD 633.82 


\section{OFERECIMENTO}

À minha família:

Gilson e Rosa,

Paulo e Ana, Vera

e

Gabriel.

Com amor. 


\section{AGRADECIMENTOS}

Ao Prof. Dr. Quirino Augusto Camargo Carmello, pela orientação, incentivo, confiança e amizade.

Ao Prof. Dr. Francisco Antonio Monteiro e Prof. Dr. Antonio Roque Dechen pelo apoio, confiança, incentivo e amizade.

Aos colegas e amigos do Instituto Agronômico: Odair Alves Bovi, Marilene Leão Alves Bovi, Fernando Romariz Duarte, Maria Beatriz Calheiros, Márcia Ortiz Mayo Marques, Marco Antonio Teixeira Zullo, Newton do Prado Granja, Teresa Losada Valle, Hipólito Mascarenhas, Heitor Cantarella, Ondino Clêante Bataglia, José Antonio Quaggio, Pedro Roberto Furlani, Mônica Ferreira de Abreu, Cleide Aparecida de Abreu, Renata Presta, Arlete de Jesus e Carlos Eduardo de Oliveira Camargo.

Aos professores e funcionários da ESALQ: Edgar Gomes Ferreira de Beauclair, Valdomiro Corrêa de Bittencourt, Luíz R. F. Alleoni, Márcio R. Lambais, Guerd Sparoveck, Luiz Inácio Prochnow, Álvaro Pires da Silva, Nivanda Maria de Moura e Lurdes Aparecida Dário de Gonzáles, Carlos Tadeu dos Santos Dias e Sônia Maria De Stefano Piedade, Luzia Fátima S. Passato, Silvana C. Nascimento Oliveira, Álvaro Sobreiro Filho, Airton Luis Barbosa, Eliana M. G. Sabino e Katia M. A. Ferraz.

A Glaucia Maria Bovi Ambrosano professora de Bioestatística da UNICAMP.

A João Luiz Delucca e à Quest International.

A Christina Helena Rupp de Paiva Gonçalves e Antonio Carlos Ramos Gonçalves e ao CEL-LEP - Sorocaba.

Aos estagiários: Vanessa Salvadego Decasellato Elias, Queiroz, Glâucia Regina Anti, Giuliana Etori do Valle, Cristiane Conti Zanata, Bárbara Casellato Elias, Adriana Margutti, Marcelo Galzerani, Maxmiliano Salles Scarpari e Alessandra Carla Fattori.

Ao produtor Laudo J. L. Bernardes.

Aos colegas, alunos do Curso de pós-graduação em Solos e Nutrição de Plantas, que geraram discussões e sugestões que contribuiram com este trabalho.

Aos dirigentes do Instituto Agronômico que, nos dificeis momentos por que tem passado a instituição durante o período de desenvolvimento deste trabalho, compreenderam e colaboraram para que as dificuldades que surgiram fossem solucionadas para a conclusão do curso.

À CAPES pela bolsa de estudos. 


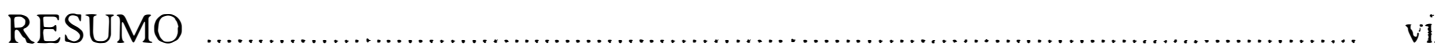

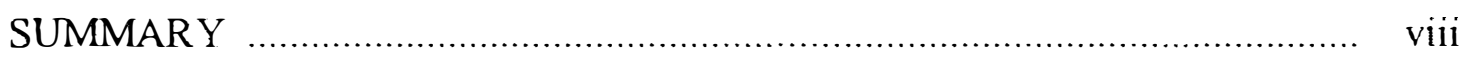

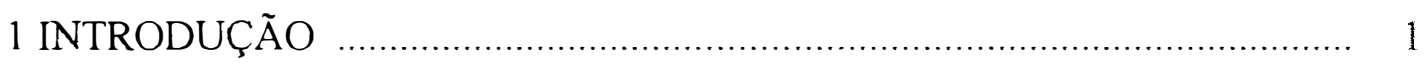

2 REVISÃO DE LITERATURA _................................................................. 4

3 MATERIAL E MÉTODOS _................................................................ 13

3.1 Local de cultivo das plantas ............................................................... 13

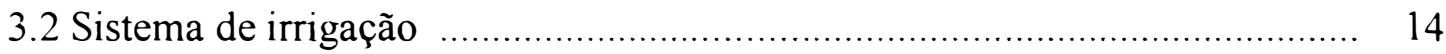

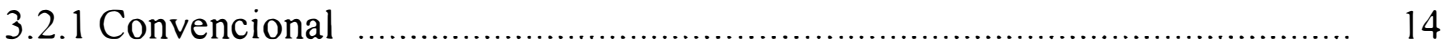

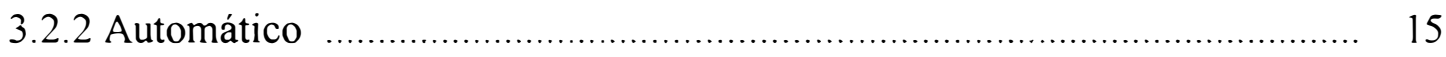

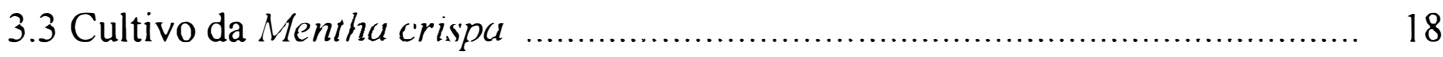

3.4 Cultivo de Mentha arvensis L ............................................................ 18

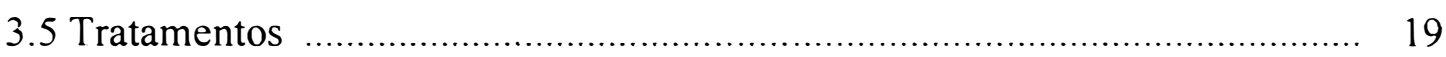

$3.6 \mathrm{pH}$ e condutividade elétrica da solução ………………………………....... 22

3.7 Contagem do número de folhas ………........................................... 23

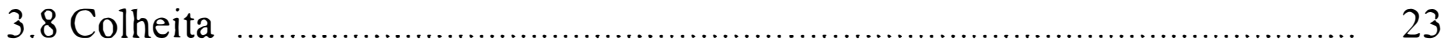

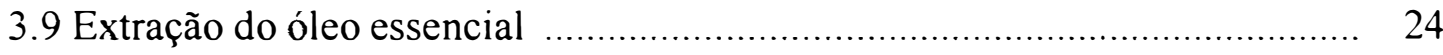

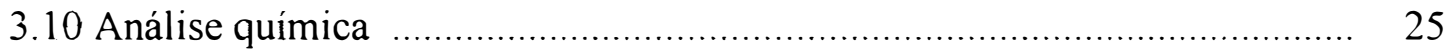

3.11 Estimativa do teor de clorofila através do valor SPAD ............................. 25

3.12 Análise cromatográfica e espectrometria de massas ................................ 26

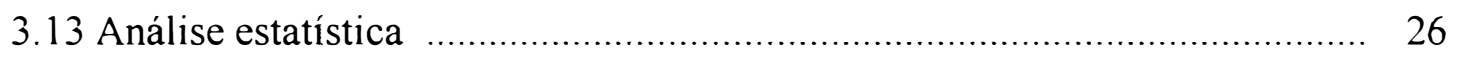

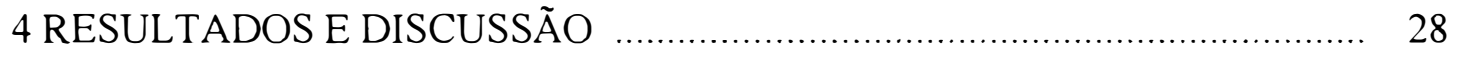

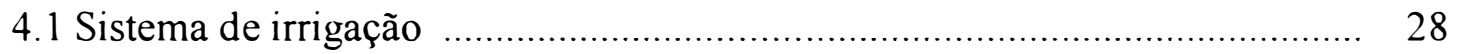

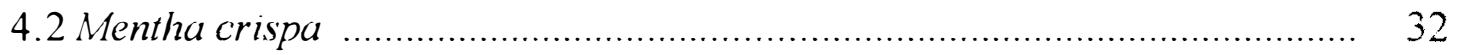

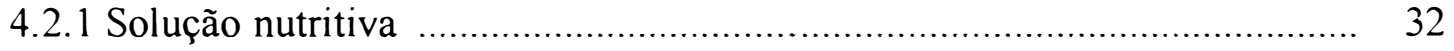

$4.2 .1 .1 \mathrm{pH}$

4.2.1.2 Condutividade elétrica ……….................................................... 35

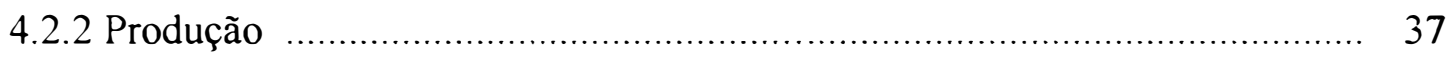

4.2.2.1 Massa de material seco ................................................................ 37

4.2.2.2 Número de pares de folhas ......................................................... 39

4.2.3 Teores de nutrientes na parte aérea ..................................................... 41

4.2.3.1 Efeito das doses de $\mathrm{N}$ nos teores de nutrientes na parte aérea ............... 43

4.2.3.2 Efeito das doses de $\mathrm{P}$ nos teores de nutrientes na parte aérea ................ 46 
4.2.3.3 Efeito das doses de $\mathrm{K}$ nos teores de nutrientes na parte aérea ............... 47

4.2.3.4 Efeito das doses de $\mathrm{Ca}$ nos teores de nutrientes na parte aérea .............. 49

4.2.3.5 Efeito das doses de $\mathrm{Mg}$ nos teores de nutrientes na parte aérea ............. 50

4.2.4 Teores de nutrientes nas raízes ........................................................ 51

4.2.5 Estimativa do teor de clorofila através do valor SPAD _........................... 54

4.2.6 Composição do óleo essencial ………………….................................... 55

4.2.7 Solução nutritiva recomendada _.......................................................... 59

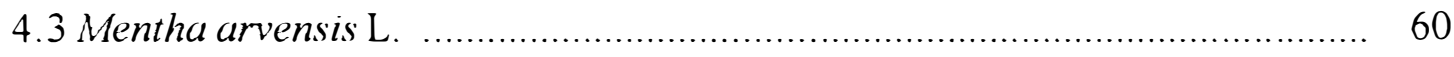

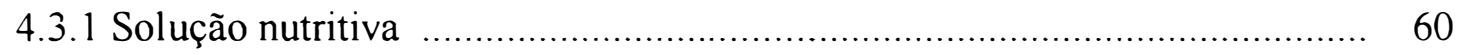

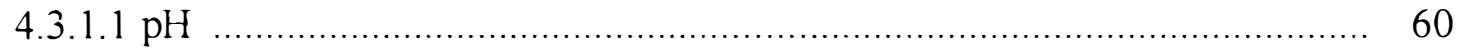

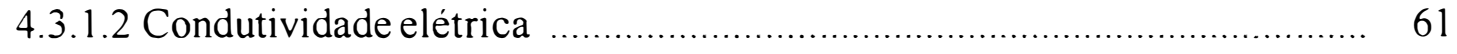

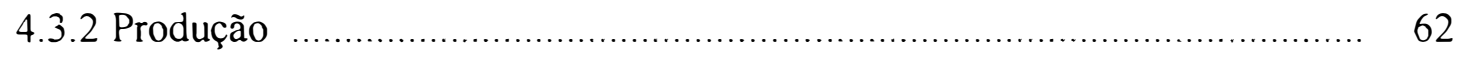

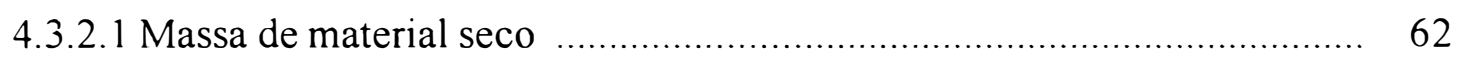

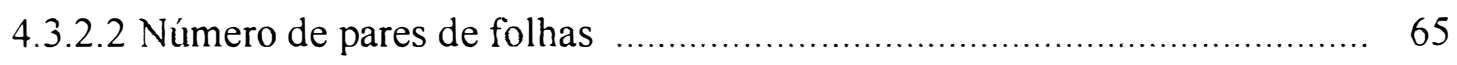

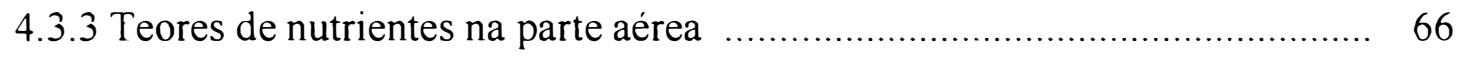

4.3.3.1 Efeito das doses de $\mathrm{N}$ nos teores de nutrientes parte aérea .................... 68

4.3.3.2 Efeito das doses de $\mathrm{P}$ nos teores de nutrientes na parte aérea ............... 70

4.3.3.3. Efeito das doses de $\mathrm{K}$ nos teores de nutrientes na parte aérea ............... 70

4.3.3.4 Efeito das doses de $\mathrm{Ca}$ nos teores de nutrientes na parte aérea .............. 73

4.3.3.5 Efeito das doses de $\mathrm{Mg}$ nos teores de nutrientes na parte aérea ............. 73

4.3.4 Teores de nutrientes nas raízes ...................................................... 74

4.3.5 Estimativa do teor de clorofila através do valor SPAD ……................... 78

4.3.6 Rendimento do óleo essencial ........................................................ 79

4.3.7 Composição do óleo essencial ………………................................... 82

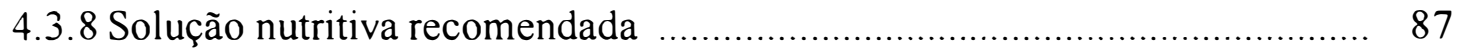

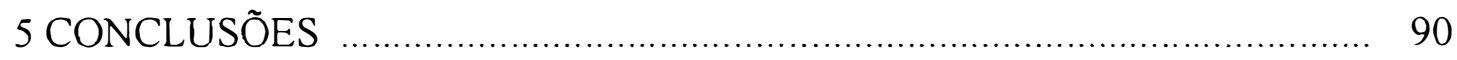

REFERÊNCIAS BIBLIOGRÁFICAS _.......................................................... 91 


\title{
PRODUÇÃO E QUALIDADE DO ÓLEO ESSENCIAL DE DUAS ESPÉCIES DE MENTA CULTIVADAS EM SOLUÇÕES NUTRITIVAS
}

\author{
Autor: NILSON BORLINA MAIA \\ Orientador: Prof. Dr. QUIRINO A. C. CARMELLO
}

\section{RESUMO}

Com o objetivo de definir as soluções nutritivas especificas para o cultivo de Mentha arvensis L. e Mentha crispa, as quais possibilitassem uma produção de óleo essencial de boa qualidade e um método de cultivo com grande capacidade de produção, desenvolveu-se um sistema automático para o fornecimento de solução, especifico para este trabalho de nutrição das plantas.

O sistema consistia de um conjunto de reservatórios equipados com motobombas individuais, controlados por bóias de nivel da solução nos vasos e um temporizador. Nos experimentos com plantas de hortelã (M. crispa), a produção de folhas no sistema proposto foi superior à produção do sistema de fornecimento de solução normalmente utilizado no setor de Nutrição Mineral de Plantas do Departamento de Quimica da Escola Superior de Agricultura "Luiz de Queiroz" - USP.

Utilizando-se esse sistema, instalou-se um experimento para cada espécie. A partir da formulação de uma solução normalmente utilizada nos experimentos (controle), preparou-se outras 10, nas quais, dobrou-se ou reduziu-se pela metade, a concentração dos nutrientes $\mathrm{N}, \mathrm{P}, \mathrm{K}, \mathrm{Ca}$ e $\mathrm{Mg}$, de modo que as duas espécies foram cultivadas em soluções com três concentrações de cada um dos nutrientes estudados. 
Os experimentos foram instalados em um delineamento inteiramente casualizado, com quatro repetições. Foram avaliados: a evolução do número de folhas, o teor de clorofila, a produção de material seco da parte aérea e das raizes e a concentração do óleo essencial na parte aérea das plantas. Determinou-se a concentração de cada elemento estudados nas diferentes partes das plantas.

O óleo essencial, extraido pelo processo de destilação por arraste de vapor, foi analisado em cromatógrafo a gás, acoplado a espectrômetro de massa, onde identificouse as principais substâncias presentes em cada óleo e seus respectivos teores.

O sistema automático de fornecimento de soluções nutritivas para as plantas apresentou uma capacidade de produzir até três vezes mais material vegetal do que o convencional, o que compensou seu menor rendimento em produção de óleo $(0,62 \%$ contra $0,74 \%$ do convencional), além da diferença na qualidade do mesmo.

Observou-se que as soluções nutritivas mais ricas em $\mathrm{N}$ para a $M$. crispa e mais concentradas em K e Ca para a $M$. arvensis L. são capazes de aumentar o rendimento de massa de material vegetal e de óleo produzido, sem que a qualidade do óleo essencial seja prejudicada. 


\title{
ESSENTIAL OIL PRODUCTION AND QUALITY OF TWO MENTHA SPECIES GROWN IN NUTRIENT SOLUTIONS
}

\author{
Author: NILSON BORLINA MAIA \\ Advisor: Prof. Dr. QUIRINO A. C. CARMELLO
}

\section{SUMMARY}

The objectives of this work were to define specific nutrient solutions for the culture of Mentha arvensis L. and Mentha crispa which would allow high quality essential oil production and the development of a culture method with high yield capacity. To achieve this goal, a specific automatic solution dispenser was developed.

The system consisted of a group of reservoirs equipped with individual pumps. The solution level was controlled by buoys and a timer. In a preliminary test, $M$. crispa leaves production was higher when grown in this system than when the same plants were grown in the system normally used in the Plant Nutrition Section of the Chemistry Department of the Escola Superior de Agricultura "Luiz de Queiroz" - USP. One experiment was installed for each species.

The basic solution that is routinely used in our work was the starting point for the formulation of testing solutions and was also used as control. Ten different solutions were prepared from the basic solution. Double and half strength solutions for $\mathrm{N}, \mathrm{P}, \mathrm{K}$, $\mathrm{Ca}$ and $\mathrm{Mg}$ were prepared in such a way that the two species were cultured in solutions containing three different concentrations of each of the nutrients focused in this study. 
The experimental design was completely radomized with four replications. Number of leaves, chlorophyll content, and shoots and roots dry matter production were evaluated. Each element concentration was determined in the plant material obtained.

The essential oil was extracted by steam destillation and analysed for its main components and its concentrations in a gas chromatographer coupled to a mass spectrometer.

The plants grown in the automatic dispenser of plant nutrient solution system presented a three times increase in dry matter when compared to plants grown in the conventional system. Whereas the oil production was lower in the former $(0.62 \%$ in contrast to $0.74 \%$ ) than the conventional growth system. There was also differences in oil quality. 


\section{INTRODUÇÃO}

Estudou-se o comportamento da nutrição, crescimento, produção e qualidade do óleo essencial da Mentha crispa e Mentha arvensis L. através de um sistema automático de fornecimento de solução nutritiva especialmente desenvolvido para este trabalho.

As duas espécies de plantas, aromáticas, pertencem à família Labiatae. A $M$. crispa destaca-se pelo uso culinário e de chás com efeito medicinal. Como a maioria das plantas usadas como condimento na culinária nacional, sua comercialização não é quantificada e os estudos agronômicos são muito restritos. Também é comercializada in natura como planta medicinal e empregada popularmente como vermífugo, ememagoga, eupéptica e antiasmática. Recentemente, tem sido comprovado cientificamente sua ação amebicida em Entamoeba histolytica e giardicida em Giardia lamblia. A inexistência de trabalhos sobre a nutrição dessa planta, o potencial econômico que apresenta para o cultivo em hidroponia, as semelhanças com a $M$. arvensis L., que permitem comparações entre as espécies, além das perspectivas medicinais, influiram na escolha para o estudo.

A segunda espécie, a Mentha arvensis L. é produtora de um óleo essencial, rico em mentol, cujas aplicações nas indústrias farmacêutica, de higiene e do tabaco, lhe conferem uma importância econômica muito grande e por isso é mais estudada e há um acervo científico muito maior do que o disponível para a $M$. crispa.

O Brasil já foi o maior produtor mundial de $M$. arvensis L. e de mentol. As primeiras lavouras da década de 40 foram introduzidas pelos imigrantes japoneses, que levaram a planta para a região de Presidente Prudente, no Estado de São Paulo e, posteriormente, para o norte e oeste do Estado do Paraná, de onde, finalmente, se 
deslocou para o Paraguai. Essa produção foi possivel, graças aos solos férteis daquelas regiões, que entre as décadas de 50 e 70 eram fronteiras agrícolas, em intenso processo de desmatamento. O desaparecimento da produção nacional deu-se, essencialmente, por problemas de fertilidade de solo e nutrição de plantas, o que justifica os estudos nessas áreas do conhecimento, para possibilitar o retorno de seu cultivo.

A cultura da $M$. arvensis $\mathrm{L}$. era estabelecida em áreas de matas recém derrubadas e queimadas, onde a planta, exigente quanto às condições de nutrição, era cultivada com vantagens econômicas por alguns poucos anos. Devido à pouca tecnologia agrícola empregada pelos produtores e ao esgotamento da fertilidade original do solo e das cinzas das queimadas, as lavouras passavam a ser implantadas em novas áreas de derrubada de matas virgens, estabelecendo um processo predatório de exploração do solo. Com o fim do desmatamento no Estado do Paraná, desapareceu a produção da planta e de mentol nacional.

Outro fator que contribuiu para o final da produção nacional de menta foi o advento do mentol sintético que, por ser mais barato, diminuiu a demanda e participação do mentol natural no mercado internacional. A suscetibilidade da planta à ferrugem, uma doença causada pelo fungo Puccinia menthae foi outro fator importante para a redução da área plantada.

Porém, a simplicidade de produção do mentol natural, associado à elevação do custo do mentol sintético e, principalmente, a crescente demanda por produtos de elevada qualidade, faz com que o óleo essencial natural de menta e o mentol dele obtido retomassem sua importância comercial .

A retomada da produção nacional de menta, embasada em uma tecnologia que possibilite uma boa produtividade de óleo e que não necessite ser cultivada em áreas desmatadas e queimadas, possibilitaria o retorno do fornecimento brasileiro ao mercado de óleo de menta, numa situação privilegiada. Esse mercado comercializa mais de 5.000 ton ano $^{-1}$ de óleo, que em valores históricos da ordem de US $\$ 10,00 \mathrm{~kg}^{-1}$, perfaz US $\$ 50$ milhões ano $^{-1}$. A exigência crescente dos principais mercados por produtos naturais, de boa qualidade e de origem certificada, gerados sem desmatamento ou outros tipos de 
agressão ao ambiente, será uma vantagem adicional ao detentor desse novo produto, sendo que o interesse pelo produto tem aumentado.

Sob esses aspectos, a produção comercial de menta em solução nutritiva, ou hidroponia, mostra-se bastante promissora. A literatura especializada mostra rendimentos de óleo essencial até cinco vezes superior ao obtido em cultivos convencionais, com teor de mentol superior ao cultivo normal em solo, evidenciando que a maior ou menor disponibilidade de determinados nutrientes pode alterar as rotas bioquímicas especificas, que por sua vez irão produzir componentes do óleo essencial em proporções diferentes, resultando em óleos com qualidades distintas.

A facilidade de manipulação do meio nutritivo nos cultivos com solução nutritiva permite a produção de óleos diferenciados, tanto na qualidade quanto na quantidade, conforme diversos autores têm demonstrado em estudos cientificos. Porém, para obter-se óleo essencial em quantidade e qualidade que contemple as exigências do mercado, é necessário que se defina vários parâmetros para subsidiar as produções comerciais, principalmente sobre os aspectos nutricionais

Por esse motivo o presente trabalho visa determinar os efeitos das concentrações de alguns nutrientes ( $\mathrm{N}, \mathrm{P}, \mathrm{K}, \mathrm{Ca}$ e $\mathrm{Mg}$ ), sobre a qualidade e a quantidade do óleo essencial da Menta arvensis L. e Mentha crispa cultivadas em solução nutritiva e determinar alguns parâmetros para um cultivo comercial mais eficiente.

Para tanto, buscou-se determinar uma solução nutritiva que proporcione uma produção ótima de óleo essencial de boa qualidade, avaliar o grau de interrelação entre os principais componentes do óleo e a concentração dos nutrientes na solução e avaliar a possibilidade de produção de óleos diferenciados a partir do cultivo da planta em soluções nutritivas diferentes. 


\section{REVISÃO DE LITERATURA}

A importância das plantas que são objetos deste estudo reside nos seus óleos essenciais, encontrados em células oleiferas distribuidas pelas folhas e conjuntos florais da planta (Fischer \& Hecht-Buchholz, 1985), das quais são extraídos na razão média de $1 \%$ do peso do material destilado (Brilho, 1969).

Apesar da importância farmacêutica (Garcia et al., 1996) e do valor desse óleo essencial como aroma e perfume (Correa, 1969; Greenhalg, 1979; Broderick, 1993), o papel biológico da maioria dos metabólitos secundários das plantas, categoria na qual esse produto se enquadra, ainda é relativamente pouco conhecido. Na verdade, não se conhece a função biológica da maioria desses metabólitos, uma classe de substâncias para as quais as plantas investem uma quantidade significativa de energia na sua produção (Lewinsohn, 1996; Tuomi et al., 1991).

Metabólitos secundários são definidos como compostos químicos orgânicos, de origem vegetal ou animal, que não têm, ou ainda não se conhece, função direta sobre as atividade bioquimicas de crescimento, desenvolvimento e reprodução. Com o avanço do conhecimento acumulado na bioquímica, espera-se que esse conceito seja alterado. Mais recentemente, muitos autores já passaram a dar preferência ao uso do termo "produtos naturais", evitando a conotação de menor importância que o adjetivo secundário, erroneamente, sugere. No entanto, os dois termos designam o mesmo grupo de substâncias e são usados indiscriminadamente na literatura científica (Bell, 1981; Luckner, 1972).

Uma parte dessas substâncias podem apresentar propriedades de interesse industrial, alimentício e farmacológicas. Várias plantas que apresentam concentrações 
elevadas dessas substâncias têm uma grande importância econômica e são cultivadas nas mais diversas regiões (Crocomo et al., 1981).

A partir da década de 70 , os estudos sobre as interações de plantas e insetos foram intensificados, focando-se a química da planta, em particular dos metabólitos secundários (Lindroth, 1991). Segundo Edwards \& Wratten (1981) mais de 30 mil estruturas de compostos vegetais conhecidos estariam relacionados com os mecanismos de defesa das plantas. Uma vez que as plantas não podem escapar das pressões ambientais movimentando-se, suas únicas defesas são suas estruturas físicas e a composição química. Há evidências abundantes para sugerir que muitas substâncias do metabolismo secundário vegetal exercem papéis importantes nas relações entre as plantas e os organismos doentes e entre os animais herbivoros e seus alimentos.

As altas concentrações desses metabólitos encontrados em algumas plantas são o resultado da evolução de um mecanismo de proteção, desenvolvido pela pressão da herbivoria (Ricklefs, 1990) ou, como descobriu-se recentemente, uma resposta ao ataque de insetos (Paré \& Tumlinson, 1997), ou doenças, pois essas substâncias diminuem as taxas de crescimento de patógenos e a virulência em algumas espécies (Krischik, 1991).

Esses metabólitos também desempenharam um papel importante na história da química, sendo possível perceber esta influência até a atualidade. As teorias químicas da Grécia antiga postulavam que toda a matéria seria feita de quatro elementos: terra, ar, fogo e água. Os discípulos de Pitágoras e Aristóteles acrescentaram um quinto elemento, que supunha-se compor os corpos celestes: o éter. Na procura desse quinto elemento (quinta essentia), os alquimistas desenvolveram uma pesquisa extensa com os óleos voláteis de diversas hervas e especiarias, que acabaram por originar métodos de destilação e liquores tradicionais como o Benedictine e Chartreuse, onde os óleos essenciais são componentes importantes (Loomis \& Croteau, 1980).

Os óleos essenciais são uma mistura de diversos compostos orgânicos, que no caso das mentas, predominam os terpenos. Essas moléculas são hidrocarbonetos de fórmula geral $\left(\mathrm{C}_{10} \mathrm{H}_{16}\right)_{\mathrm{n}}$, encontrados como componentes de óleos essenciais, ou resinas 
extraídos de diversos vegetais. Além do óleo de menta, os óleos essenciais de eucalipto e laranja são exemplos de óleos ricos em compostos terpênicos (Bohe et al., 1980).

Os terpenos são classificados em função da quantidade de unidades de hidrocarbonetos que os formam, ou do número que o valor " $n$ " da fórmula assume. Para $n=1 / 2$, têm-se hemiterpenos; quando $n=1$, terpenos; $n=2$ diterpenos, etc. Esta é a regra dos terpenos, como define Loomis \& Croteau (1980). A biossíntese dos terpenos iniciase com a acetil coenzima A (Acetil CoA), cuja interação com as diferentes rotas metabólicas dos organismos é esquematizada na figura 1.

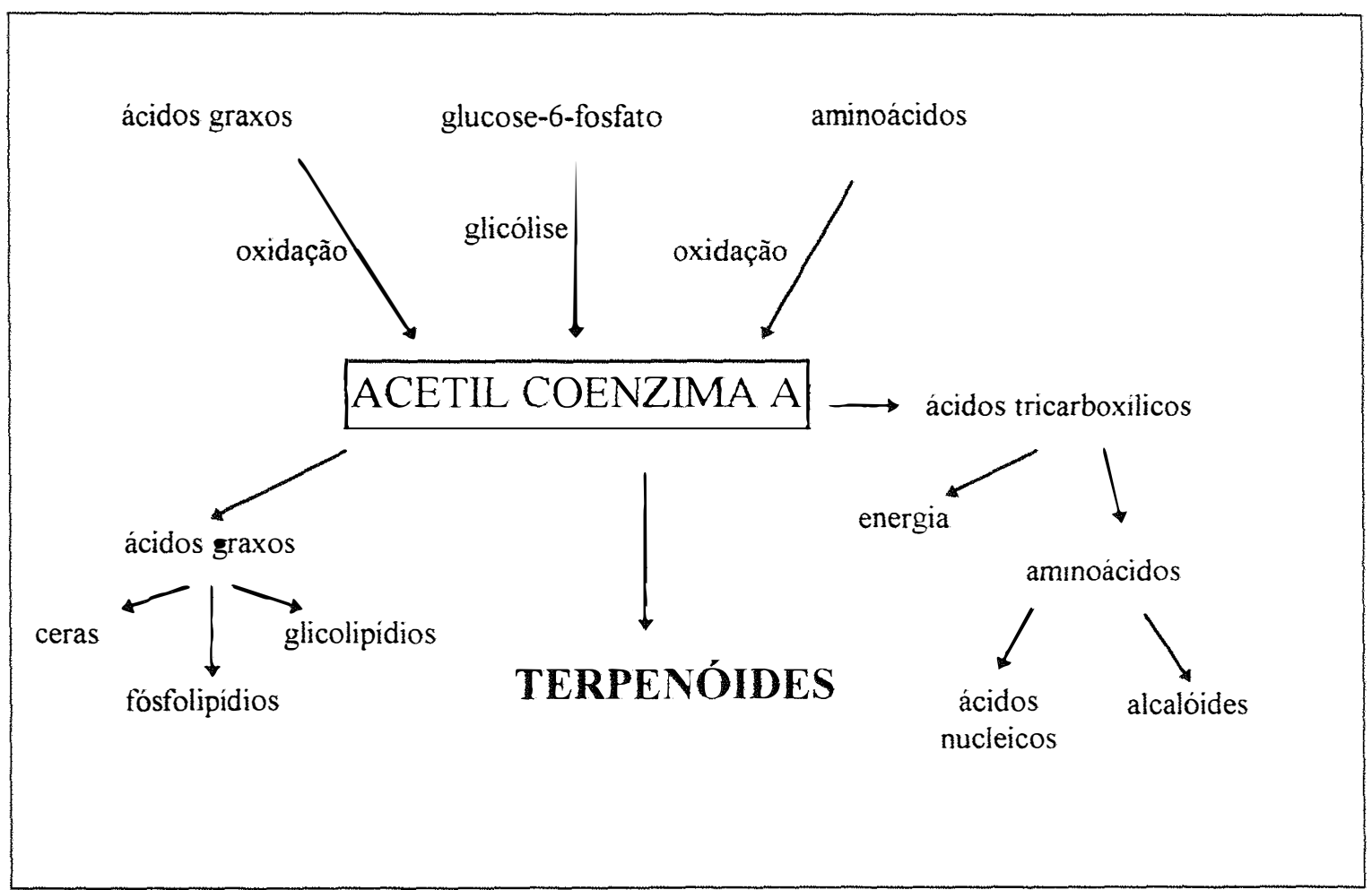

Figura 1. Interação da acetil coenzima A com o metabolismo dos organismos. Adaptado de Vickery \& Vickery (1981).

A rota que leva à formação do hemiterpeno, é intermediada pelo ácido malevônico (MVA), isopreno pirofosfato (IPP) e, finalmente o dimetil pirofosfato ou hemiterpeno (DMAPP), conforme elucidam Vickery \& Vikery (1981) na figura 2. 


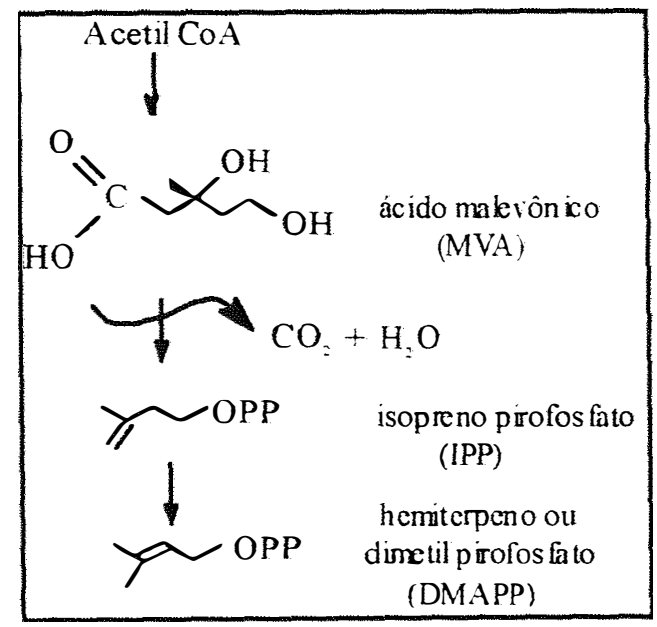

Figura 2. Biosintese de hemiterpenos. Adaptado de Vickery \& Vickery (1981).

Assim é formada a primeira unidade com 5 carbonos, que por polimerização, pela regra dos terpenos, irá formar monoterpenos, diterpenos, etc. (Loomis \& Croteau, 1980). Neste caso, o limoneno (Figura 3) é a molécula de interesse que irá originar as principais substâncias dos óleos essenciais estudados.

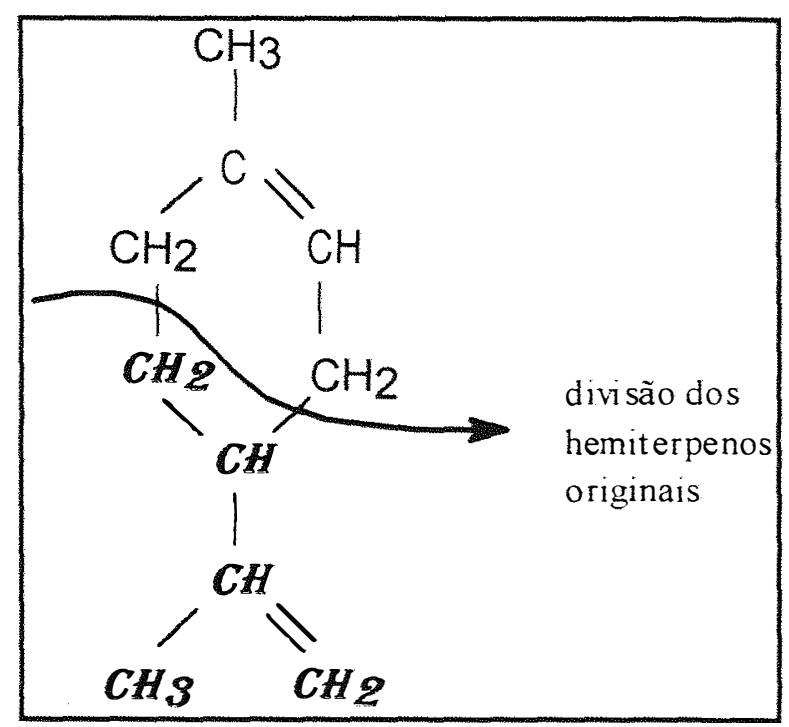

Figura 3. Estrutura do limoneno com indicação das duas sub-unidades de hemiterpenos que originaram a molécula. Cada um dos dois hemiterpenos originais estão grafados com tipos de letras diferentes. Adaptado de Loomis \& Croteau (1980) e Merck (1968). 
$\mathrm{Na}$ figura 4, uma adaptação de Lewinsohn (1996), Charlwood \& Charlwood (1990) e Merck (1968), é esquematizada a sintese do mentol e da carvona, as duas principais substâncias do óleo essencial da $M$. arvensis L. e $M$. crispa. Nessa figura observa-se a atuação de duas enzimas: a limoneno 3-hidroxilase e a limoneno 6hidroxilase, que têm o limoneno como substrato. A primeira., responsável pelo acúmulo de mentol, ocorre na M. arvensis L., a segunda acumula carvona nas folhas da M. crispa.

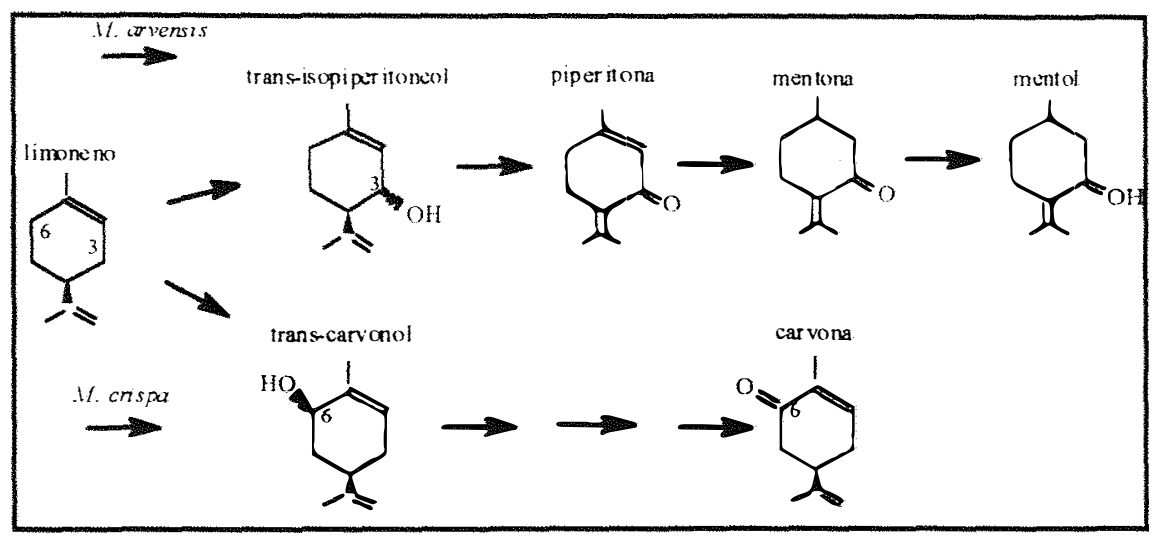

Figura 4. Formação de mentol e carvona a partir do limoneno.

O quadro 1 mostra as características físicas médias de óleos essenciais de Mentha arvensis $\mathrm{L}$. de diversas proveniências.

Quadro 1. Características físicas do óleo essencial de Mentha arvensis L.

\begin{tabular}{|lcc|}
\hline Característica & Valor mínimo & Valor máximo \\
\hline Peso específico a $25^{\circ} \mathrm{C}$ & 0,876 & 0,898 \\
Rotação Optica & $-29^{\circ} 12^{\prime}$ & $-42^{\circ} 48^{\prime}$ \\
Índice de refração & 1,14577 & 1,14695 \\
Teor de mentol total & $65,2 \%$ & $88,9 \%$ \\
Teor de mentil-acetato & $4,5 \%$ & $18,9 \%$ \\
\hline
\end{tabular}

Fontes: Guenther (1949); Merck (1968) 
As diferentes ações biológicas das plantas devem-se à atividade de compostos orgânicos, que no caso das mentas ocorrem em grande quantidade no óleo essencial. Trabalhos recentes de farmacologia mostram que alguns desses compostos, como mentol, cineol, limoneno e pineno (Almirall et al., 1996), aumentam a absorção cutânea de drogas antinflamatórias (Kabayashi et al., 1996) e age como broncodilatador (Saraiva et al., 1994; De Lorenzi, 1996). A ação expectorante, devido à ação mucocinética provocada pela leve irritação que provoca no trato respiratório já era conhecida há mais de um século (Ziment, 1982).

Além do uso farmacêutico, que exige matéria prima de boa qualidade (Schilcher, 1988), o mentol destaca-se como matéria prima importante em outras indústrias, conforme mostra o quadro 2. Devido a esse interesse industrial, é comum a prática de extrair-se uma parte do mentol contido no óleo, cristalizando-o em baixas temperaturas, e comercializar-se o resíduo (Murray et al., 1972), chamado de óleo dementolado, mais rico em mentona, que também tem importância econômica (Guenther, 1949; Santos, 1993; Clark, 1994).

Quadro 2. Principais consumidores de mentol por produto e região $\left(\mathrm{Mg}_{\mathrm{ano}}{ }^{-1}\right)$.

\begin{tabular}{|lccccc|c|}
\hline Produto & Ásia & $\begin{array}{c}\text { América } \\
\text { do Norte }\end{array}$ & Europa & $\begin{array}{c}\text { América } \\
\text { Latina }\end{array}$ & Outros & Total \\
\hline Higiene bucal & 450 & 350 & 500 & 300 & 250 & 1850 \\
Fámacos & 750 & 200 & 400 & 100 & 100 & 1550 \\
Tabaco & 300 & 800 & 100 & 100 & 50 & 1350 \\
Confeitos & 200 & 80 & 100 & 140 & 50 & 570 \\
Creme de barbear & 40 & 50 & 80 & 50 & 30 & 250 \\
Outros & 10 & 20 & 20 & 10 & 20 & 80 \\
\hline Total & 1750 & 1500 & 1200 & 700 & 500 & 5650 \\
\hline
\end{tabular}

Fonte: Clark (1988). 
Outros usos potenciais desse óleo tem sido pesquisado. Pesquisas têm mostrado um controle efetivo de fungos importantes na agricultura, como Alternaria sp., Curvularia lunauta, Fusarium moniliformae, F. solani e Rizoctonia bataticola (Singh et al., 1983). Outros autores observaram além do efeito fungicida, um papel antibacteriano, com importante controle no desenvolvimento de Salmonella sp. e Staphylococcus sp. E controle de insetos em grãos e alimentos armazenados (Singh et al., 1992).

A M. arvensis L. já foi definida há muito tempo como uma planta exigente quanto à nutrição (Finnemore, 1926; Guenther, 1949). A proporção entre as poucas raizes e a parte aérea da espécie foi apontado por Maia (1994) como um fator importante nessa característica da planta.

A inexistência de trabalhos de nutrição com $M$. crispa foi um dos motivos que levou à escolha da espécie para a comparação com a M. arvensis L. Apesar dessa última espécie contar com um maior número de referências, a literatura a ela dedicada ainda é restrita se comparada a outras espécies com importância econômica semelhante

Os estudos de nutrição de M. arvensis L. se concentrou na Índia, onde tem sido cultivada nos férteis solos do norte (Nair et al.., 1991; Misra, 1995). O nitrogênio é o nutriente com maior capacidade de aumento de produção de folhas, principalmente quando cultiva-se variedades melhoradas. Kothari et al.(1987) concluiu que $150 \mathrm{~kg} \mathrm{ha}^{-1}$ era a melhor dose de $\mathrm{N}$ para variedades melhoradas. Há interações fortes entre a quantidade de $\mathrm{N}$ aplicada nas lavouras e a época da adubação de cobertura, forma do adubo (comum, granulado, super-granulado) ou recoberto e a irrigação (Ram et al., 1989). Doses entre zero e $200 \mathrm{~kg} \mathrm{ha}^{-1}$ de $\mathrm{N}$ não chegaram a alterar o rendimento de óleo nos trabalhos de Singh \& Singh (1989). Limitações na disponibilidade do nutriente causam alterações na composição do óleo e redução no crescimento de folhas, hastes e raízes e as plantas apresentam folhas amareladas sem a pilosidade característica, com pontas mais arredondadas, conforme registrou Maia (1994).

A interação do N com o P fica bastante evidente no trabalho de Sing \& Singh (1968), que demonstra que a disponibilidade desbalanceada dos dois nutrientes 
compromete a síntese de aminoácidos e, conseqüentemente, a de proteínas e a produção de folhas. Os sintomas de deficiência observados pelos autores foram semelhantes os relatados por Maia (1994): leve coloração marrom na face dorsal das folhas mais velhas e hastes avermelhadas. Nesse último trabalho, observa-se que a omissão de P na solução nutritiva aumentou em mais de $20 \%$ a concentração do mentol no óleo essencial.

O fósforo, cuja recomendação em culturas comerciais é de $30 \mathrm{~kg} \mathrm{ha}^{-1}$ (Subrahmanyam et al., 1991), é determinante no rendimento da lavoura convencional, tanto pela dose aplicada, como pela profundidade e distância da linha em que é aplicado, pois as raizes, relativamente pequenas, da planta não têm capacidade de se desenvolverem até regiões mais distantes da linha de plantio, em busca do nutriente (Kothari et al.., 1987)

Os poucos trabalhos encontrados sobre menta e $K$, mostram que o nutriente têm uma influência forte na absorção de $\mathrm{N}$, taxa de respiração, e teor de óleo essencial (Sinha \& Singh, 1984). Maia (1994) descreveu as plantas deficientes no nutriente, como apresentando desenvolvimento lento, redução do número de brotações e folhas menores, que apresentavam pouca pilosidade e manchas necróticas, das pontas para o centro das folhas mais velhas.

Um dos poucos trabalhos com Mentha arvensis $\mathrm{L}$. e Ca, encontrado na literatura é o de Maia et al.(1996), que demonstrou a importância da presença do nutriente no ataque da bactéria Pseudomonas cichoril. Não encontrou-se na literatura, estudos específicos sobre $\mathrm{Mg}$ e $\mathrm{S}$ com M. arvensis $\mathrm{L}$.

$\mathrm{O}$ efeito do Fe e $\mathrm{Zn}$ na nutrição da Mentha arvensis L. foi mais estudado na Índia, devido às características dos solos calcáreos onde a planta é cultivada. Farooqi \& Misra (1983), relataram redução de até 50\% no teor de óleo das plantas deficientes. Misra \& Sharma (1991a) determinaram 5,6 $\mathrm{mg} \mathrm{L}^{-1}$ de Fe, como sendo o nível crítico do nutriente na solução nutritiva. Misra \& Sharma (1991b) determinaram $28,0 \mathrm{mg} \mathrm{kg}^{-1} \mathrm{e}$ $0,0475 \mathrm{mg} \mathrm{L}^{-1}$ como os níveis críticos de $\mathrm{Zn}$, respectivamente nas folhas e solução nutritiva. Os autores descreveram os sintomas visuais da deficiência: as folhas pequenas, com clorose internerval no terceiro par de folhas e internódios curtos. Misra (1995) 
alertou para os efeitos da toxidez e carência do nutriente, responsável pela ativação enzimática em diversas reações, e também determinou que o nível crítico de $\mathrm{Zn}$ nas folhas é de $17 \mathrm{mg} \mathrm{kg}^{-1}$ e o de toxidez $46 \mathrm{mg} \mathrm{kg}^{-1}$.

O manejo da cultura da $M$. arvensis L. é determinante na produção de folhas e óleo essencial. Czepak (1995) mostrou que a frequência do corte viabilizava produções de mais de $4000 \mathrm{~kg} \mathrm{ha}^{-1}$ de material seco por corte e até $338 \mathrm{~L} \mathrm{ha}^{-1}$ ano $^{-1}$ de óleo essencial, quando colheu-se em intervalos de 60 dias, sem que houvesse queda do teor de mentol no óleo. Com a ressalva de que se dê condições nutricionais adequadas às plantas, o autor faz oposição às recomendações mais antigas (Chiris, 1925; Brilho, 1969), que recomendavam a colheita no periodo de florescimento, para obter-se maiores rendimentos de mentol.

Mairapetyan (1984) mostrou que é possível a produção de até cinco vezes a mais de óleo essencial em cultivos com solução nutritiva do que na mesma área de solo, obtendo-se óleo com até $60 \%$ de mentol, enquanto que as plantas cultivadas em solo produziram óleo com apenas $49 \%$. Esses dados mostram que estudos complementares poderão viabilizar o cultivo da planta em diferentes condições geográficas, resultando em produto de alta qualidade (Duhan et al., 1977; Denys et al., 1990), trazendo vantagens para os produtores, sem a necessidade de desmatamentos de áreas virgens para a instalação de lavouras, o que justifica o trabalho aquí apresentado. 


\section{MATERIAL E MÉTODOS}

Foram cultivadas Mentha crispa (hortelã) e Mentha arvensis L.(menta japonesa) em 11 soluções nutritivas para determinar-se as melhores concentrações de nutrientes, para a produção e a qualidade do óleo essencial. Devido à grande quantidade de tratamentos, desenvolveu-se um sistema automático de irrigação, que foi comparado com o sistema utilizado no setor de Nutrição Mineral de Plantas do Departamento de Quimica da Escola Superior de Agricultura "Luiz de Queiroz" - USP, que neste trabalho será designado como sistema de irrigação convencional.

\subsection{Local de cultivo das plantas}

Os experimentos foram desenvolvidos em casa-de-vegetação no Setor de Nutrição Mineral de Plantas, do Departamento de Química, da Escola Superior de Agricultura "Luiz de Queiroz" - USP, Piracicaba, Estado de São Paulo. As coordenadas são $22^{\circ} 42^{\prime} 30^{\prime}$ 'S e 47 38' 00" W, a uma altitude de 546m acima do nivel do mar. 


\subsection{Sistema de irrigação}

\subsubsection{Convencional}

Os vasos plásticos com 3,6 L de capacidade, continham quartzo moído e, tinha inserida na sua parte inferior, uma mangueira flexível de $6 \mathrm{~mm}$ de diâmetro interno, fixada de modo a permitir a retirada da solução por gravidade. O orificio de entrada dessa mangueira foi protegido por uma tela plástica, para evitar-se entupimento.

Neste sistema, semelhante ao descrito por Haag \& Carmello (1984), a extremidade livre da mangueira, cinco $\mathrm{cm}$ mais comprida que a altura do vaso, era mantida acima da superficie da sílica, de modo a manter a solução em contato com as raízes. A solução era aplicada pela manhã e drenada 6 a 8 horas mais tarde, quando a extremidade livre da mangueira era inserida num vasilhame $(1 \mathrm{~L})$ instalado abaixo do nível da base do vaso, coletando-se a solução para ser usada no próximo período (Figura $5)$.

O sistema convencional recebeu solução nova ( 1 L por vaso) no plantio, aos 13 , 21, 28, 43 e 51 dias após o plantio. Entre esses dias, quando a quantidade de solução diminuía pela metade devido à evapotranspiração, completava-se o volume até um litro, com água destilada. 


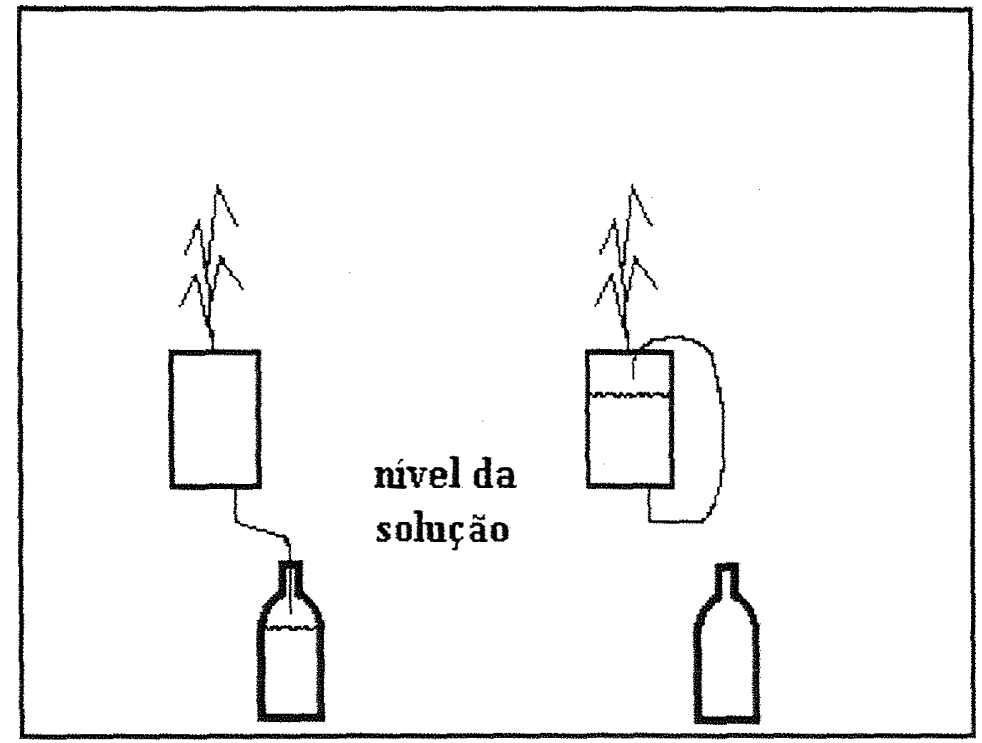

Figura 5. Sistema manual (convencional) de fornecimento de solução nutritiva. À esquerda observa-se o vaso sendo drenado e à direita o vaso inundado com solução.

\subsubsection{Automático}

O sistema desenvolvido consistiu num conjunto composto por quatro vasos idênticos ao já descrito, mas com as mangueiras de drenagem conectadas à uma moto-bomba submersa num tambor plástico contendo $22 \mathrm{~L}$ da solução, instalado abaixo dos vasos, de modo que a mesma mangueira promovia a drenagem e a alimentação dos vasos com a solução. A moto bomba de 0,14 A, com capacidade de elevação de $0,7 \mathrm{~m}$, utilizada em aquários domésticos, foi escolhida pelo seu custo reduzido, sua capacidade de trabalho por longos períodos sem manutenção e blindagem plástica com eixo de aço inoxidável, inertes à solução. A saída da bomba foi conectada a uma mangueira de 1/2", de onde derivou-se até as bases dos vasos, 4 tubos de $6 \mathrm{~mm}$ de diâmetro com 2,5 $\mathrm{m}$ de comprimento, que possibilitou o deslocamento dos vasos para as posições sorteados na instalação e durante a condução do experimento (Figura 6). 


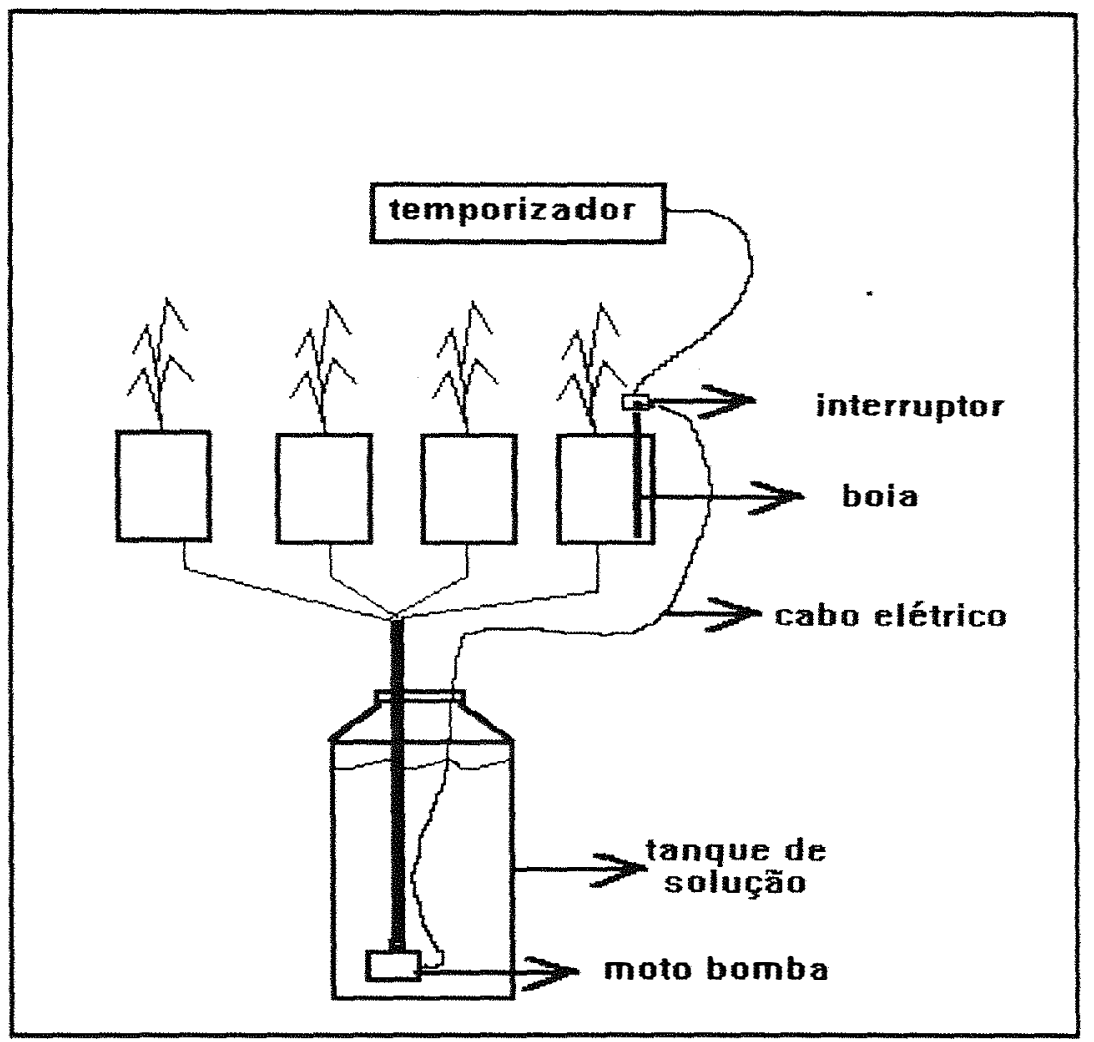

Figura 6. Sistema automático de fornecimento de solução nutritiva para quatro vasos, simultaneamente.

Como a vazão de cada uma das moto bombas não era idêntica, cada uma delas era controlada por um sensor de nível de solução, instalado em um dos 4 vasos do conjunto, que ligava e desligava a moto-bomba durante os seis minutos de rega, de modo a manter o nível da solução constante em todos os quatro vasos, sem transbordamentos.

Esse sensor foi montado com um tubo de PVC de 3/4", contendo uma seringa de injeção descartável de $10 \mathrm{ml}$, cujo bocal da agulha foi vedado e colocado para baixo dentro do tubo, de modo que a mesma flutuasse, com a elevação da solução. O êmbolo da seringa acionava a alavanca de um internuptor elétrico do tipo "micro-switch" de 10 A, fixado no topo do tubo de PVC, no qual passava a corrente elétrica para a moto bomba (Figura 7). Desse modo, sempre que o nível da solução chegava ao máximo, o êmbolo elevava a alavanca do interruptor, desligando a moto-bomba, permitindo o 
retorno da solução ao tambor. Com o abaixamento do nível de solução no vaso, a seringa descia, seu êmbolo liberava a alavanca do interruptor, que acionava novamente a moto-bomba, mantendo assim, o nível máximo da solução nos vasos variando entre um a dois centímetros, até que decorressem os 6 minutos controlados pelo temporizador, quando então a energia elétrica era desligada e as soluções retornavam para os seus tambores, permitindo assim a oxigenação das raízes pelas próximas 3 horas, quando reiniciava-se o ciclo.

O nível máximo de solução no vaso podia ser regulado pela posição do êmbolo da seringa. Quando puxado ao máximo, na marca de $10 \mathrm{ml}$, o nível da solução no vaso era baixo, pois tão logo a seringa flutuava, o êmbolo acionava o interruptor. Empurrando o êmbolo para dentro, na marca de 1 ou $2 \mathrm{ml}$, a seringa precisa flutuar até um nível mais alto para acionar o interruptor, mantendo o nível final da solução mais elevado.

Durante o dia, o sistema automático era ligado pelo temporizador durante seis minutos a cada hora nos primeiros 13 dias a contar do plantio. Depois o sistema passou a ser ligado a cada três horas. Durante o período de escuro (noite), o sistema fazia uma rega de 6 minutos após 5 horas sem a luz do Sol.

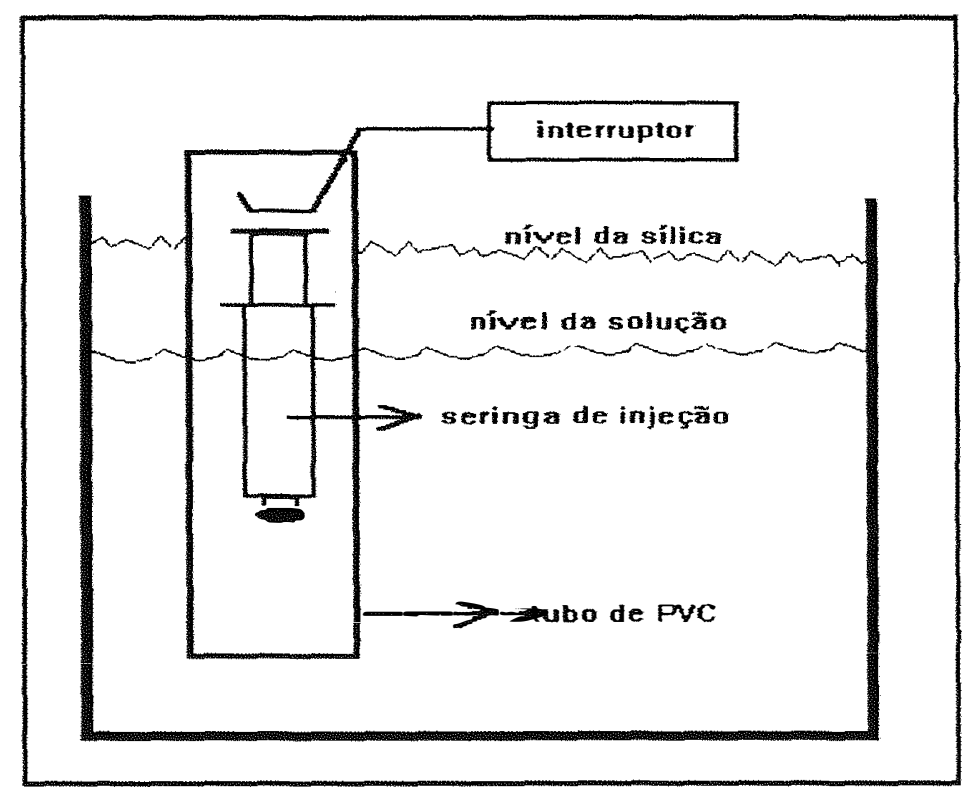

Figura 7. Bóia de controle de nível da solução no vaso 


\subsection{Cultivo da Mentha crispa}

A escolha da $M$. crispa (hortelã) para o estudo deu-se por ela ser uma espécie muito utilizada na culinária nacional; sua importância medicinal (Almeida, 1993), como vermífugo (Santana et al., 1992), e ausência de estudos agronômicos e de nutrição mineral sobre essa espécie.

Coletou-se estolões de M. crispa, provenientes dos canteiros da Seção de Plantas Aromáticas e Medicinais, do Instituto Agronômico de Campinas SP no dia 3 de março de 1997. O material vegetal foi lavado em água corrente e mantido em recipiente úmido durante um dia.

Em seguida selecionou-se estolões com 3 gemas, instalados individualmente em "tubets" plásticos com vermiculita, onde permaneceram por 14 dias para enraizamento, até o plantio de 3 mudas por vaso na instalação do experimento, no dia 17 de março de 1997.

\subsection{Cultivo de Mentha arvensis $\mathbf{L}$.}

Utilizou-se a variedade IAC-701 de $M$. arvenis L. devido à sua importância medicinal, comercial e adaptação às condições brasileiras (Maia, 1994), além da boa produção agrícola, teor de mentol, óleo essencial (Czepak, 1995) e resistência à ferrugem causada por Puccinia menthae Per., de larga ocorrência no Brasil (Donalísio et al., 1985).

Devido à pequena quantidade de material disponível para multiplicação, foi feito enraizamento de explantes de estolões com aproximadamente $1 \mathrm{~cm}$ de comprimento. Para um melhor aproveitamento do material, proveniente da Seção de Plantas Aromáticas e Medicinais, do Instituto Agronômico de Campinas SP, os estolões foram 
colhidos e lavados em água corrente abundante, desinfectados em solução de hipoclorito de sódio a $1 \%$ e manipulados em condições assépticas em câmaras de fluxo laminar, conforme recomendado por Mroginski \& Roca (1991). O enraizamento ocorreu em frascos de vidro de $100 \mathrm{ml}$ que continham aproximadamente $1 \mathrm{~cm}$ de meio MS (Murashige \& Skoog, 1962) no seu fundo, solidificado com ágar, conforme descrito por Caldas et al. (1990). Cada frasco recebeu 5 explantes e foram depositados em câmara de crescimento por 25 dias.

Após esse período, selecionou-se as plântulas que continham pelo menos 5 folhas, lavou-se suas raizes para eliminação do meio aderido, que foram plantadas em placas de isopor, próprias para a produção de mudas de hortaliças (Plantmax ${ }^{\circledR}$ ) com células piramidais preenchidas com vermiculita.

As placas foram cobertas com plástico transparente e ficaram flutuando sobre a solução nutritiva com a composição do tratamento controle (Tabela 1), em casa-devegetação. Após cinco dias, quando as mudas apresentavam vigor caracteristico de adaptação ao novo meio, o plástico foi removido.

Quando as raizes começaram a expandir-se na solução, pelos orifícios inferiores das placas, plantou-se 3 mudas por vaso, no dia 11 de julho de 1997.

\subsection{Tratamentos}

Para a comparação entre os sistemas de fornecimento de solução, automático e convencional, foi feito o cultivo de 8 vasos de M. crispa no sistema convencional e outros 8 vasos com a mesma espécie no sistema automático, agrupados em 2 conjuntos de reservatório e moto-bombas, com 4 vasos cada um, descrito no item 3.2.2. As soluções utilizadas nos dois tratamentos foram elaboradas de maneira idêntica, conforme Sarruge (1975), descrita detalhadamente como controle na tabela 1.

O estudo sobre as concentrações de nutrientes nas soluções, foi feito com 11 tratamentos, repetidos quatro vezes. Eles consistiram de um tratamento controle, 
conforme a solução proposta por Sarruge (1975) e por outras 10, com o dobro ou a metade das concentrações de nutrientes, elaboradas conforme as tabelas 1 e 2 . O S foi o único macronutriente não estudado, devido à sua grande concentração nos poluentes da atmosfera local, o que poderia vir a contaminar as parcelas.

Para maior facilidade, os tratamentos serão designados pelo símbolo do elemento cuja concentração foi alterada, seguido pelo número que indica sua concentração em $\mathrm{mg} \mathrm{L}^{-1}$. O tratamento controle tem, portanto, a concentração média de todos os nutrientes estudados. 


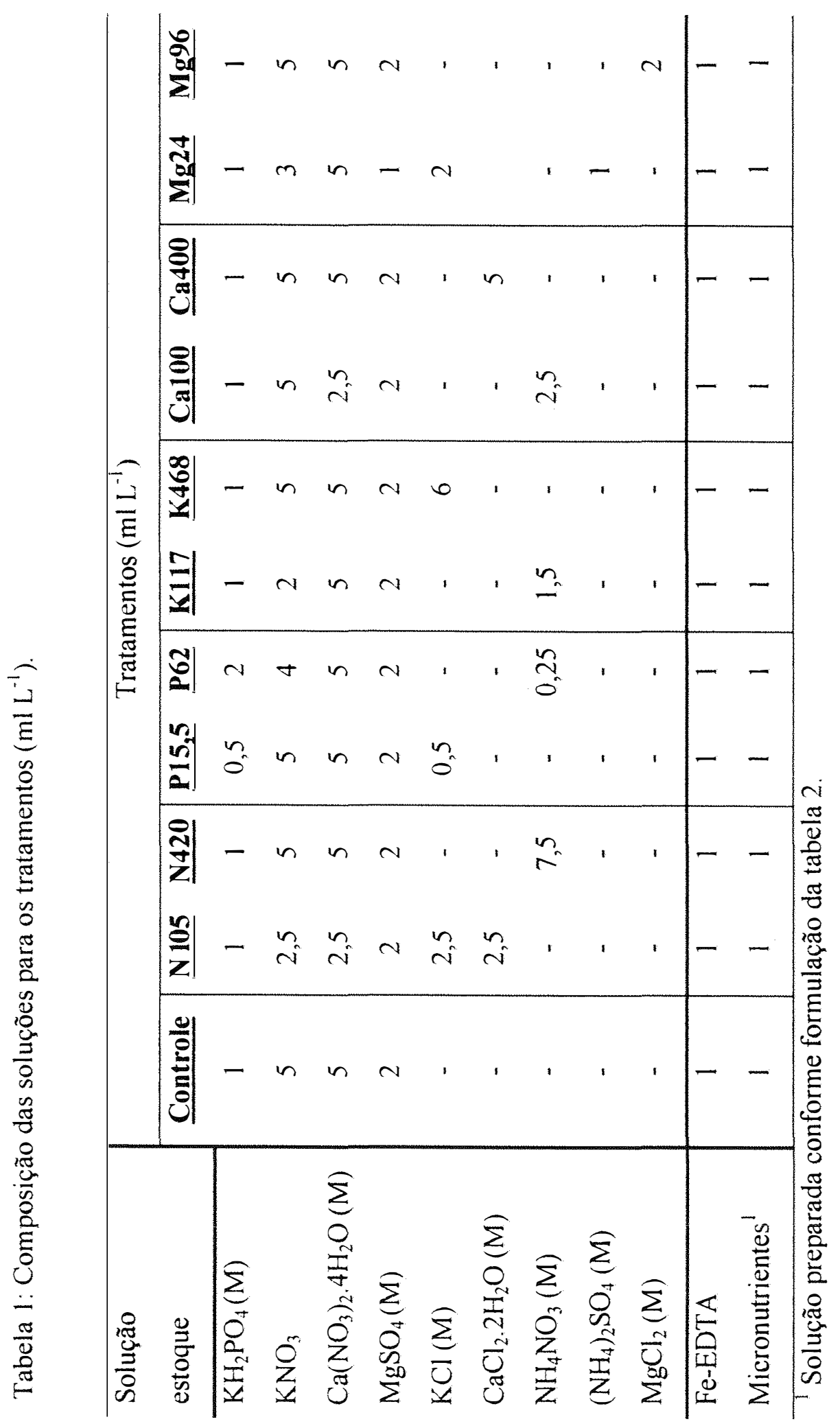


O ferro foi fornecido através de uma solução contendo 26,1 g de EDTA; 11,5 g de soda cáustica e $24,9 \mathrm{~g}$ de sulfato ferroso por litro. A solução preparada foi submetida a aeração durante um dia antes de sua utilização.

Tabela 2: Solução estoque de micronutrientes.

\begin{tabular}{lc}
\hline Reagente & $\mathrm{g} \mathrm{L}^{-1}$ \\
\hline $\mathrm{H}_{3} \mathrm{BO}_{3}$ & 2,85 \\
$\mathrm{Mn} \mathrm{Cl}_{2} \cdot 4 \mathrm{H}_{2} \mathrm{O}$ & 1,81 \\
$\mathrm{Zn} \mathrm{Cl}_{2}$ & 0,10 \\
$\mathrm{CuCl}_{2}$ & 0,04 \\
$\mathrm{H}_{2} \mathrm{MoO}_{4} \cdot \mathrm{H}_{2} \mathrm{O}$ & 0,02 \\
\hline
\end{tabular}

\section{6 pH e condutividade elétrica da solução}

$\mathrm{O} \mathrm{pH}$ e a condutividade elétrica das soluções foram determinados diretamente nos reservatórios de soluções de cada um dos tratamento, com aparelhos portáteis.

As leituras foram feitas sempre após completar-se o volume de solução com água destilada e a agitação para devida homogeneização, esperando-se a estabilização dos indicadores dos aparelhos. No experimento com M. crispa o pH das soluções foram determinados no dia da elaboração e instalação do experimento, nos $28^{\circ}, 36^{\circ}, 43^{\circ}, 57^{\circ} \mathrm{e}$ $64^{\circ}$ dias após o plantio. As leituras da condutividade elétrica, determinada $\mathrm{em} \mathrm{mS} \mathrm{cm}^{-1}$, foram feitas aos $1^{\circ}, 50^{\circ}$ e $64^{\circ}$ dias após o plantio.

As medidas de $\mathrm{pH}$ e condutividade elétrica das soluções dos vasos cultivados no sistema convencional, foram feitas em cada um dos recipientes e, posteriormente, foram calculadas as médias. 
Os valores de $\mathrm{pH}$ das soluções dos vasos cultivados com M. arvensis L. foram medidos no plantio, aos $16^{\circ}, 36^{\circ}, 58^{\circ}$, e $67^{\circ}$ dias após o plantio, e os valores das condutividades elétricas aos $1^{\circ}, 15^{\circ}, 35^{\circ}$ e $67^{\circ}$ dias após o plantio.

\subsection{Contagem do número de folhas}

O número dos pares de folhas de cada vaso foi determinado no $30^{\circ}, 36^{\circ}, 45^{\circ} \mathrm{e}$ $64^{\circ}$ dias após o plantio da M. crispa e no $9^{\circ}, 16^{\circ}, 30^{\circ}$ e $68^{\circ}$ dia após o plantio da Mentha arvensis $\mathrm{L}$.

Não foi possivel a contagem de folhas após o $45^{\circ}$ e $30^{\circ}$ dia do plantio da $M$. crispa e M. arvensis L., respectivamente, que coincidiu com o período de maior desenvolvimento, devido às injúrias que a manipulação das hastes entrelaçadas causava às plantas.

\subsection{Colheita}

A colheita dos dois experimentos consistiu na separação do material desenvolvido acima da superfície da sílica moida e do material desenvolvido na parte subterrânea, cortando-se as hastes das plantas no seu colo (próximo à superfície da sílica). Em cada um dos vasos (parcelas) dos experimentos contou-se o número de folhas, e pesou-se a produção de massa de material verde total. Do material da parte aérea recém colhido, separou-se uma planta inteira, que apresentava um desenvolvimento médio no vaso. Esta planta foi pesada, acondicionada em saco de papel tipo Kraft e colocada para secar em estufa a $50^{\circ} \mathrm{C}$ até peso constante, quando então obteve-se seu peso depois de seco e procedeu-se sua moagem em moinho tipo Wiley. O material foi armazenado em sacos plásticos, para a posterior análise química. A produção da massa de material seco total de cada vaso foi estimada pelas proporções 
das massas de material verde e seco dessa planta e o peso de material verde total do vaso.

O restante do material, destinado à destilação por arraste de vapor, foi acondicionado em saco plástico devidamente identificado, comprimido para que a compactação diminuísse a quantidade de ar em contato com as folhas e imediatamente colocado em freezer a uma temperatura de $-15^{\circ} \mathrm{C}$, para reduzir os efeitos da oxidação sobre a qualidade do óleo essencial.

A colheita da M. crispa foi feita no dia 20 de maio de 1997, após 64 dias do plantio nos vasos. Devido à falta de literatura e recomendação específica, a colheita desta espécie foi definida em função do porte apresentado pelas plantas dos tratamentos mais desenvolvidos.

A M. arvensis L. foi colhida em 16 de setembro de 1997, após 68 dias do plantio, quando as plantas dos tratamentos mais desenvolvidos apresentavam botões florais na iminência de se abrirem, conforme Singh \& Singh (1989) preconizaram como o melhor momento para a colheita, o que coincidia com 70 dias de cultivo em solução nutritiva e areia. No trabalho de Singh \& Singh (1968), a mesma espécie apresentou o mais avançado estádio de maturação e o máximo acúmulo de óleo essencial.

\subsection{Extração do óleo essencial}

A extração do óleo essencial das folhas foi feita com destilação por arraste de vapor em aparelho de Moritz, conforme descrito por Costa (1975). O método foi escolhido, por manter o material vegetal acima da água em ebulição no gerador de vapor, como ocorre nos processos industriais de extração de óleos essenciais. Nesse

aparelho, ao contrário do aparelho de Clevenger (id. ibid.), muito utilizado nos laboratórios, por exigir pouco material, a água geradora de vapor não fica em contato direto com o material vegetal. 
Por ser um aparelho que exige um volume relativamente grande de folhas para se recuperar óleo para análise, não foi possivel destilar-se as plantas de cada um dos vasos cultivados com M. crispa. O óleo dessa espécie foi obtido da destilação do conjunto de todas as plantas de cada um dos tratamentos. Na destilação da M. arvensis L., graças ao seu maior teor de óleo essencial, foi possivel obter-se a produção de cada um dos vasos cultivados e proceder-se a análise estatística da composição do óleo.

O procedimento de manipulação e preparo do material para a destilação, foi o descrito por Shugar \& Ballinger (1990). O tempo de destilação de $50 \mathrm{~min}$. foi cronometrado a partir da queda da primeira gota condensada no funil separador.

\subsection{Análise química}

O material seco e moído, acondicionado em sacos plásticos, foi processado para a obtenção do extrato de digestão nitro-perclórica, conforme recomendado por Krug et

al. (1996) para determinação das concentrações de nutrientes. A determinação dos nutrientes foi feita segundo a metodologia de Sarruge \& Haag (1974).

\subsection{Estimativa do teor de clorofila através do valor SPAD}

Utilizou-se o valor da leitura do aparelho portátil "Clorophyll Meter SPAD-502" (Soil-Plant Analysis Development Section, Minolta Camera Co. Osaka, Japan) para estimar-se o teor de clorofila das folhas. A leitura apresentada é obtida pela transmissão de luz através da folha nos comprimentos de ondas na faixa do vermelho, $650 \mathrm{~nm}$, e infravermelho, $940 \mathrm{~nm}$, que correspondem aos picos de absorção máximo e mínimo respectivamente (Minolta Camera Co., 1989).

Após ensaios preliminares, observou-se que a menor variação de leituras numa mesma planta era obtida na folha mais nova completamente desenvolvida, o que correspondia ao terceiro ou quarto par de folhas, contados a partir do primeiro par 
aberto, no alto da haste em direção à base, que foram designadas como folhas diagnósticas.

Foram feitas leituras em doze pares de folhas diagnóstico em cada um dos vasos e calculada a média do vaso para as análises estatísticas. Na $M$. crispa foram feitas leituras aos 6, 36 e 65 dias após o plantio. Na M. arvensis L. as leituras foram feitas ao 6,37 e 67 dias após o plantio.

\subsection{Análise cromatográfica e espectrometria de massas}

A composição química do óleo essencial foi obtida em cromatógrafo a gás acoplado a espectrometro de massas (CG-EM, Shimadzu, modelo QP5000), utilizandose Hélio como gás de arraste, $1 \mu \mathrm{L}$ de amostra, injetor a $250^{\circ} \mathrm{C}$, detector a $230^{\circ} \mathrm{C}$ e o seguinte programa de temperatura: $50^{\circ} \mathrm{C}(5 \mathrm{~min})-160^{\circ} \mathrm{C}, 3^{\circ} \mathrm{C} \mathrm{min}^{-1} ; 160^{\circ} \mathrm{C}-250^{\circ} \mathrm{C}$, $10^{\circ} \mathrm{C} \mathrm{min}^{-1}$.

A identificação dos constituintes foi baseada na comparação dos espectros de massas das substâncias, com o banco de dados do sistema CG-EM (Wiley 139 Library) (McLafferty \& Stauffer, 1989) e a co-injeção dos padrões: $\alpha$-pineno, $\beta$-pineno, 1,8cineol, limoneno e carvona.

Procedeu-se a uma contra prova com amostras de $0,2 \mu \mathrm{L}$ em cromatógrafo HP5890 , com coluna capilar de $30 \mathrm{~m}$ com Carbowax $20 \mathrm{M}$, com temperatura de $100^{\circ} \mathrm{C}$ a $210^{\circ} \mathrm{C}$ a $6^{\circ} \mathrm{C} \mathrm{min}^{-1}$ e atenuação do integrador de $2 \times 10^{-9}$.

\subsection{Análise estatística}

As parcelas experimentais consistiram de um vaso com quatro plantas cada, em casa-de-vegetação. Utilizou-se um delineamento inteiramente casualizado, com quatro repetições, segundo a recomendação de Gomes (1981). As posições dos vasos foram 
sorteadas na inatalação e mais duas vezes durante a condução do experimento. Os resultados foram transformados em logaritmos de base 10 (Little \& Hills, 1972).

Utilizou-se o programa estatístico SAS Institute Corporation (1989) para análise estatística. O nível de significância adotado nos teste $\mathrm{F}$ e de médias (Tukey) em todo o trabalho foi de $10 \%$, com exceções das apontadas oportunamente.

Os estudos de regressão polinomial e múltipla, foram feitos segundo a metodologia para delineamento fatorial fracionado, para experimentos com fertilizantes, descrita por Colwell (1994). Nas regressões desenvolvidas pelo método "stepwise" ou de maximização do $\mathrm{R}^{2}$, escolhidas com o auxílio do coeficiente de paràmetros $(\mathrm{Cp})$, definido por Mallows (1973), calculou-se os coeficientes de determinação parciais, segundo Parsons (1978). 


\section{RESULTADOS E DISCUSSĀO}

\subsection{Sistema de irrigação}

As plantas de $M$. crispa cultivadas no sistema automático, desenvolvido para este trabalho e descrito no item 3.3., produziram três vezes mais material seco do que as plantas da mesma espécie cultivadas no sistema convencional, conforme observa-se na tabela 3. A maior freqüência de irrigação, no sistema automático, possibilitou uma maior aeração das raízes, disponibilidade de água e nutrientes, propiciando produções mais próximas do potencial máximo da espécie.

Tabela 3. Produção de material seco e rendimento de óleo essencial de M. crispa em dois sistemas de cultivo.

\begin{tabular}{lcccccc}
\hline \multirow{2}{*}{ Sistema } & \multicolumn{3}{c}{ Massa (g/vaso) } & \multicolumn{2}{c}{ Óleo } & Folhas \\
& Raízes & P. aérea & Total & $(\%)$ & $(\mathrm{mg} / \mathrm{vaso})$ & $\mathrm{n} /$ vaso \\
\hline Convencional & $10,43 \mathrm{a}^{1}$ & $10,85 \mathrm{a}$ & $21,28 \mathrm{a}$ & 0,74 & 80 & $141 \mathrm{a}$ \\
Automático & $31,68 \mathrm{~b}$ & $34,01 \mathrm{~b}$ & $65,69 \mathrm{~b}$ & 0,62 & 203 & $440 \mathrm{~b}$ \\
\hline
\end{tabular}

Números seguidos pelas mesmas letras, nas colunas, não diferem significativamente pelo teste de Tukey a $5 \%$ de probabilidade.

Já a concentraçào do óleo essencial nas folhas (\%) mostrou um comportamento inverso ao da produção de massa vegetal. Tal comportamento, já demonstrado e explicado por Fischer \& Hecht-Buchholz (1985), Kothari et al. (1987) e Charles et al. 
(1990), mostra que a produção de óleo essencial de folhas aromáticas não é proporcional à área foliar. Plantas muito desenvolvidas tendem a ter um menor número de células oleíferas por área de folha, apresentando um menor rendimento de óleo, que é a relação entre a massa de óleo e a massa de folhas secas. Porém, a produção de óleo por planta ( $\mathrm{g} / \mathrm{vaso}$ ), apresentou o mesmo comportamento da produção de material seco de raizes, folhas e massa total.

Na tabela 4 são apresentados os teores de nutrientes nas raizes e parte aérea das plantas cultivadas no sistema convencional e automático. Os teores significativamente mais elevados de $\mathrm{P}, \mathrm{K}$ nas raizes e de $\mathrm{P}$ nas folhas, são semelhantes aos apresentados por Trought \& Drew (1980) e Mengel \& Kirkby (1982). Marschner, (1995, pg.629), explica que as reduções dos teores de $\mathrm{N}, \mathrm{P}$ e $\mathrm{K}$ nas raizes das plantas irrigadas pelo sistema convencional deve-se pela menor tensão de oxigênio no meio. 
Tabela 4. Teores de nutrientes nas folhas e raizes de M. crispa em dois sistemas de cultivo.

\begin{tabular}{|c|c|c|c|c|}
\hline \multirow{3}{*}{ Nutrientes $^{1}$} & \multicolumn{2}{|c|}{ Raízes } & \multicolumn{2}{|c|}{ Parte aérea } \\
\hline & \multicolumn{2}{|c|}{ Sistema } & \multicolumn{2}{|c|}{ Sistema } \\
\hline & Convencional & Automático & Convencional & Automático \\
\hline $\mathrm{N}$ & $4,92 a^{2}$ & $11,11 \mathrm{~b}$ & $20,23 a$ & $21,33 a$ \\
\hline$P$ & $1,55 \mathrm{a}$ & $2,10 \mathrm{~b}$ & $2,44 a$ & $2,91 \mathrm{~b}$ \\
\hline K & $8,25 a$ & $15,88 \mathrm{~b}$ & $20,66 a$ & $21,23 \mathrm{a}$ \\
\hline $\mathrm{Ca}$ & $9,95 \mathrm{a}$ & $8,50 \mathrm{a}$ & $18,90 \mathrm{a}$ & $18,28 \mathrm{a}$ \\
\hline $\mathrm{Mg}$ & $3,70 \mathrm{a}$ & $4,41 \mathrm{a}$ & $3,71 \mathrm{a}$ & $4,88 \mathrm{~b}$ \\
\hline $\mathrm{S}$ & $1,06 \mathrm{a}$ & $0,90 a$ & $1,90 \mathrm{a}$ & $1,83 a$ \\
\hline $\mathrm{Fe}$ & $685,38 \mathrm{a}$ & $1116,75 b$ & $217,25 \mathrm{a}$ & $235,00 \mathrm{a}$ \\
\hline Mn & $11,50 \mathrm{a}$ & $34,25 b$ & $24,25 a$ & $48,13 b$ \\
\hline $\mathrm{Zn}$ & $39,00 \mathrm{a}$ & $17,37 b$ & $59,00 a$ & $47,12 b$ \\
\hline B & $23,96 a$ & $26,90 a$ & $32,99 a$ & $39,03 b$ \\
\hline
\end{tabular}

${ }^{1}$ Macronutrientes expressos em $\mathrm{g} \mathrm{kg}^{-1} \mathrm{e}$ micronutrientes em $\mathrm{mg} \mathrm{kg}^{-1}$.

${ }^{2}$ Números seguidos pelas mesmas letras, nas linhas e dentro das partes das plantas, não diferem significativamente pelo teste de Tukey a $5 \%$ de probabilidade

Na tabela 5 e figura 8 são apresentados os resultados da análise cromatográfica, evidenciando a diferença qualitativa, tanto pelos teores dos componentes comuns aos óleos produzidos nos dois sistemas, como pelo número maior de substâncias detectadas (número de picos), no sistema automático. 
Tabela 5. Teores das principais substâncias do óleo essencial da Mentha crispa em dois sistemas de cultivo.

\begin{tabular}{|c|c|c|c|}
\hline \multirow[b]{2}{*}{$\begin{array}{c}\text { Substância (nº de } \\
\text { identificação) }\end{array}$} & \multirow{2}{*}{$\begin{array}{l}\text { Tempo de } \\
\text { retenção } \\
(\min )\end{array}$} & \multicolumn{2}{|c|}{ Sistema } \\
\hline & & $\begin{array}{c}\text { Automático } \\
\qquad(\%)\end{array}$ & $\begin{array}{c}\text { Convencional } \\
(\%)\end{array}$ \\
\hline Não identificada I & 9,4 & 3,02 & 0,96 \\
\hline 1,8-cineol & 10,8 & 6,29 & 2,60 \\
\hline Limoneno & 11,3 & 11,42 & 3,58 \\
\hline Carvona & 20,0 & 69,77 & 72,06 \\
\hline Não identificada II & 25,01 & 4,15 & 18,08 \\
\hline Cariofileno & 28,47 & 0,78 & Tr. ${ }^{1}$ \\
\hline número de picos & - & 16 & 7 \\
\hline
\end{tabular}

Tr. $<0,78 \%$

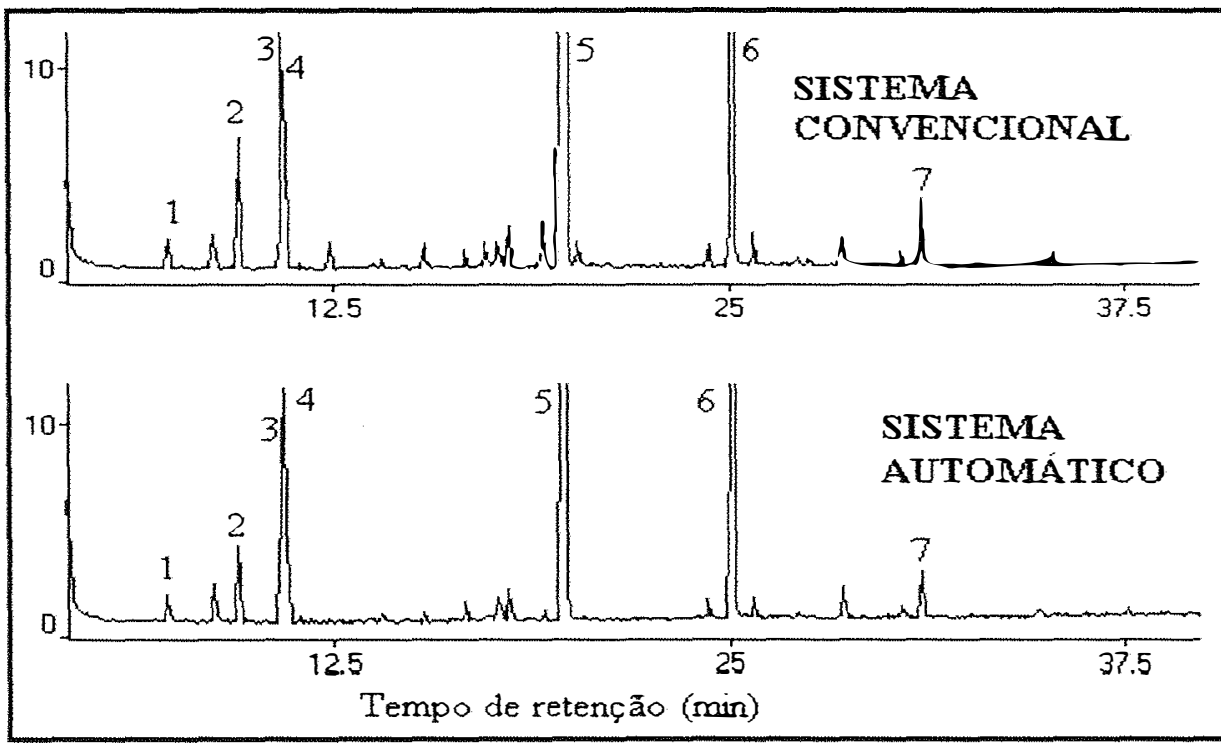

Figura 8. Cromatogramas dos óleos obtidos das plantas de Mentha crispa cultivadas nos dois sistemas de imigação. Picos: $1=\beta$-ocineno; 2 = não identificado I; $3=1,8$-cineol; 4 $=$ limoneno; $5=$ carvona; $6=$ não identificado II; $7=$ cariofileno . 
Nos trabalhos de pesquisa de nutrição mineral de plantas, o cultivo das plantas em condições que permitam uma produção próxima da máxima, é importante para a identificação dos efeitos dos fatores em estudo. Plantas cultivadas em tais condições são utilizadas como testemunhas, ou padrões. Dessa forma, efeitos eventuais de doses de nutrientes, ou outros fatores em estudo, podem ser isolados e identificados por comparação com os padrões. Os resultados mostraram, que o sistema de rega convencional limitou a produção máxima, podendo vir a mascarar ou impossibilitar a identificação de outros efeitos, como a disponibilidade de nutrientes, por exemplo. Por esse motivo, o sistema automático de fornecimento de solução deve ser preferido ao sistema convencional por proporcionar uma maior freqüência de rega, disponibilidade de água, nutrientes e, principalmente, uma maior pressão parcial de $\mathrm{O}^{2}$ nas raízes.

Observou-se ainda, que o sistema automático, além de propiciar um melhor crescimento das plantas, permite um controle acurado da solução, possibilitando medidas de consumo de água pelas plantas, pela diferença no nível da solução nos tambores e coletas de amostras para as análises químicas, sendo uma boa opção para os estudos que exijam a manipulação de soluções perigosas (tóxicas, radioativas etc.), pois o pequeno contato direto que se tem com o líquido, diminui o número de situações de risco, aumentando a segurança.

\subsection{Mentha crispa}

\subsubsection{Solução nutritiva}

\subsubsection{1 pH}

Os resultados das determinações de $\mathrm{pH}$ das soluções nos tambores, em seis momentos ao longo dos 64 dias de duração do experimento com $M$. crispa, são 
apresentados na tabela 6. Os valores de $\mathrm{pH}$ das soluções do sistema convencional são as médias das medidas de pH da solução lixiviada de cada uma das repetições do tratamento.

Os valores de $\mathrm{pH}$ do tratamento convencional são muito variáveis, devido à renovação das soluções e a reposição freqüente da água consumida. Por este motivo, apesar da composição inicial ser idêntica à composição da solução do tratamento controle, não é correto a comparação com os outros tratamentos.

Valores menores de $\mathrm{pH}$, abaixo de 6,00 , foram observados nas soluções dos tratamentos N420, Ca100 e Mg24, mostrando uma relação direta entre os valores de pH e a quantidade de $\mathrm{NH}_{4} \mathrm{NO}_{3}$ ou $\left(\mathrm{NH}_{4}\right)_{2} \mathrm{SO}_{4}$ utilizados na formulação da solução. Nas duas primeiras soluções, utilizou-se 7,5 e $2,5 \mathrm{mM} \mathrm{L}^{-1}$ de nitrato de amônio, respectivamente e $1 \mathrm{mM} \mathrm{L}^{-1}$ de sulfato de amônio no tratamento $\mathrm{Mg} 24$.

Os efeitos do $\mathrm{pH}$ da solução sobre o desenvolvimento das plantas é conhecido há muito tempo. De um modo geral, valores baixos de $\mathrm{pH}$ afetam negativamente a absorção dos cátions, enquanto que a absorção dos ânions não sofre grandes alterações (Marshner, 1995). O mesmo autor ressalta a importância da forma em que o $\mathrm{N}$ é fornecido para as plantas, em meio com pH baixo, onde espera-se uma maior absorção de $\mathrm{N}$ nítrico e menor absorção de $\mathrm{N}$ amoniacal. Esses efeitos serão discutidos oportunamente no item 4.2.3.1, relativo ao efeito das doses de $\mathrm{N}$ sobre os teores de nutrientes na parte aérea. 
Os teores menores de $\mathrm{Mn}$ observados, principalmente, nas raizes das plantas do tratamento convencional, deve-se à diminuição do potencial de óxido-redução, que ocorre em ambientes submetidos a inundação. Segundo Borkert (1991), em potenciais de óxido-redução baixos, forma-se sulfeto de manganês, tornando o elemento menos disponivel à planta. $\mathrm{O}$ encharcamento excessivo também seria o responsável pelos teores menores tanto do Mn como de Fe, segundo Bataglia (1988) e Lopes \& Carvalho (1988).

O teor menor de $\mathrm{Zn}$, nas folhas e raízes, no tratamento automático, deveu-se ao efeito antagônico com Fe e Mn, conforme descreveram Souza \& Ferreira (1991) e Sajwan \& Lindsay (1986).

Tabela 6. Valores de $\mathrm{pH}$ das soluções usadas no cultivo da M. crispa..

\begin{tabular}{lccccccc}
\hline & \multicolumn{7}{c}{ Dias após o plantio } \\
\cline { 2 - 7 } Tratamentos & 0 & 28 & 36 & 43 & 57 & 64 & média \\
\cline { 2 - 7 } Controle & 5,52 & 6,30 & 6,80 & 6,80 & 6,80 & 6,60 & $6,47 \mathrm{a}$ \\
N105 & 5,76 & 6,30 & 7,00 & 6,80 & 5,70 & 6,50 & $6,34 \mathrm{a}$ \\
N420 & 5,38 & 4,05 & 5,00 & 4,85 & 5,10 & 5,30 & $4,94 \mathrm{c}$ \\
P15,5 & 5,91 & 6,70 & 7,30 & 6,90 & 6,80 & 6,50 & $6,69 \mathrm{a}$ \\
P62 & 5,31 & 6,00 & 6,70 & 6,60 & 6,20 & 5,80 & $6,10 \mathrm{ab}$ \\
K117 & 5,37 & 5,50 & 6,35 & 6,60 & 6,70 & 6,40 & $6,15 \mathrm{ab}$ \\
K468 & 5,80 & 6,20 & 6,80 & 6,80 & 6,85 & 6,30 & $6,45 \mathrm{a}$ \\
Ca100 & 5,50 & 4,55 & 4,30 & 5,30 & 4,85 & 5,20 & $4,95 \mathrm{c}$ \\
Ca400 & 5,72 & 6,10 & 6,65 & 6,65 & 6,90 & 6,60 & $6,44 \mathrm{a}$ \\
Mg24 & 5,67 & 5,50 & 5,75 & 6,40 & 6,70 & 4,50 & $5,75 \mathrm{~b}$ \\
Mg96 & 5,63 & 6,20 & 6,90 & 6,90 & 7,00 & 6,50 & $6,52 \mathrm{a}$ \\
Convencional & 5,52 & 5,10 & 7,20 & 7,20 & 7,60 & 6,70 & $6,76 \mathrm{a}$ \\
\hline
\end{tabular}

Números seguidos pelas mesmas letras, na coluna de médias, não diferem significativamente pelo teste de Tukey a $10 \%$ de probabilidade. 


\subsubsection{Condutividade elétrica}

A condutividade elétrica da solução nutritiva é um parâmetro importante a ser monitorado, pois está relacionado com a concentração dos nutrientes na solução e subsidia a decisão da renovação da solução ou reposição dos nutrientes (Resh, 1986). Nas condições de produção comercial, onde se adiciona diariamente ao sistema um volume de solução nova, suficiente para repor a que foi consumida, ocorre um aumento gradativo da condutividade elétrica. Por isso é recomendada a substituição de toda a solução, quando esta atingir o valor de $4 \mathrm{mS} \mathrm{cm}^{-1}$. No caso de se completar o volume da solução com água, ocorre uma queda da condutividade e a solução deve ser trocada

quando se atingir valores menores que $1 \mathrm{mS} \mathrm{cm}^{-1}$ (Carmello, 1997; Carmello \& Rossi, 1997).

Os valores de condutividade elétrica das soluções, apresentados na tabela 7 , indicam a variabilidade que esse parâmetro sofre em função da composição inicial de cada solução e da absorção das plantas à medida que as plantas se desenvolvem. As soluções que contém valores maiores de condutividade elétrica não apresentam, obrigatoriamente, uma maior concentração de nutrientes. Por este motivo, neste trabalho, optou-se por não trocar a solução em função de um limite da condutividade elétrica, mas sim em função da disponibilidade para a planta, de uma determinada quantidade de nutriente no início do experimento, completando-se, periodicamente, a solução com água destilada. 
Tabela 7. Evolução da condutividade elétrica $\left(\mathrm{mS} \mathrm{cm}^{-1}\right)$ das soluções nos diferentes tratamentos da M. crispa.

\begin{tabular}{lccc}
\hline \multirow{2}{*}{ Tratamentos } & \multicolumn{3}{c}{ Dias após o plantio } \\
\cline { 2 - 4 } Controle & 1 & 50 & 64 \\
\cline { 2 - 4 } & & \multicolumn{3}{c}{$\left(\mathrm{mS} \mathrm{cm}^{-1}\right)$} \\
\hline N105 & 1,70 & 0,654 & 0,22 \\
\hline N420 & 1,80 & 0,70 & 0,60 \\
\hline P15,5 & 2,40 & 0,31 & 0,02 \\
P62 & 1,80 & 0,40 & 0,16 \\
\hline K117 & 2,00 & 0,17 & 0,05 \\
K468 & 1,60 & 0,33 & 0,20 \\
\hline Ca100 & 2,40 & 1,18 & 0,24 \\
Ca400 & 1,60 & 0,07 & 0,01 \\
\hline Mg24 & 2,70 & 1,65 & 0,69 \\
Mg96 & 1,80 & 1,06 & 0,30 \\
\hline
\end{tabular}

$\mathrm{Na}$ média das três avaliações, somente a variação de $\mathrm{K}$ e Ca na solução, apresentaram efeitos significativamente diferentes do controle. A correlação entre a condutividade elétrica da solução e o número de dias após o plantio, concentração de $\mathrm{K}$ e Ca na solução nutritiva, é expressa pela eq. (1):

$$
\begin{aligned}
\mathrm{Y} & =1,417+3,44 \times 10^{-6} \times \mathrm{Ca}^{2}+8,23 \times 10^{-6} \times \mathrm{KCa}-2,737 \times 10^{-2} \times \mathrm{D} \\
\mathrm{R}^{2} & =0,923
\end{aligned}
$$

Onde:

$\mathrm{Y}=$ Condutividade elétrica $\mathrm{em} \mathrm{mS} \mathrm{cm}^{-1}$;

$\mathrm{K}=$ Concentração de $\mathrm{K}$ na solução em $\mathrm{mg} \mathrm{L}^{-1}$; 
$\mathrm{Ca}=$ Concentração de Ca na solução em $\mathrm{mg} \mathrm{L}^{-1}$;

$\mathrm{D}=$ Número de dias após o plantio.

Observa-se que o número de dias após o plantio é o principal responsável pela definição da condutividade elétrica da solução. $O$ calculo dos $R^{2}$ parciais para as variáveis números de dias após o plantio $(\mathrm{D})$, interação $\mathrm{K} \mathrm{Ca}$ na solução $(\mathrm{KCa})$ e quadrado da concentração de $\mathrm{Ca}$ na solução $\left(\mathrm{Ca}^{2}\right)$, foram de 0,$807 ; 0,104$ e 0,013 respectivamente.

\subsubsection{Produção}

\subsubsection{Massa de material seco}

A tabela 8 mostra o efeito dos nutrientes estudados sobre a produção de massa de material seco da parte aérea e das raizes de $M$. crispa. Destaca-se o efeito positivo do N na produção total de massa de material seco das folhas e do Ca na produção das raizes. $\mathrm{O}$ incremento do $\mathrm{N}$ na solução nutritiva proporcionou uma grande capacidade de aumento da produção da parte aérea, o que é positivo, visto que as folhas são a parte de interesse comercial da planta.

A relação entre a massa da parte aérea e das raizes nas doses N105, N2 10 (Controle) e N420, de 0,45;1,23 e 1,01, respectivamente, são semelhantes aos apresentados por (Marschener, 1995), indicando que um nivel ótimo de $N$ na solução nutritiva está entre as doses dos tratamentos N210 e N420, o que proporcionaria uma planta mais equilibrada entre suas necessidades de absorção dos nutrientes e água, principalmente no seu estádio final de desenvolvimento (id. ibid.). 
Tabela 8. Produção de massa de material seco das raizes e da parte aérea de $M$. crispa, em função dos teores de nutrientes na solução nutritiva.

\begin{tabular}{lccc}
\hline & \multicolumn{3}{c}{ Massa de material seco $(\mathrm{g})$} \\
\cline { 2 - 4 } Tratamentos & Raízes & Parte aérea & Total \\
\cline { 2 - 4 } Controle & $27,57 \mathrm{a}$ & $34,03 \mathrm{a}$ & $61,60 \mathrm{a}$ \\
\hline N105 & $50,31 \mathrm{~b}$ & $22,37 \mathrm{a}$ & $72,68 \mathrm{ba}$ \\
N420 & $44,53 \mathrm{~b}$ & $45,12 \mathrm{~b}$ & $89,64 \mathrm{~b}$ \\
\hline P15,5 & $32,37 \mathrm{a}$ & $36,87 \mathrm{a}$ & $69,23 \mathrm{a}$ \\
P62 & $28,12 \mathrm{a}$ & $41,05 \mathrm{a}$ & $69,16 \mathrm{a}$ \\
\hline K117 & $35,78 \mathrm{ab}$ & $36,21 \mathrm{a}$ & $71,99 \mathrm{a}$ \\
K468 & $19,33 \mathrm{~b}$ & $32,69 \mathrm{a}$ & $52,02 \mathrm{a}$ \\
\hline Ca100 & $16,77 \mathrm{a}$ & $27,61 \mathrm{a}$ & $44,38 \mathrm{~b}$ \\
Ca400 & $42,35 \mathrm{~b}$ & $23,19 \mathrm{a}$ & $65,54 \mathrm{a}$ \\
\hline Mg24 & $44,24 \mathrm{~b}$ & $33,03 \mathrm{a}$ & $77,27 \mathrm{a}$ \\
Mg96 & $33,81 \mathrm{ab}$ & $32,62 \mathrm{a}$ & $66,43 \mathrm{a}$ \\
\hline
\end{tabular}

Números seguidos pelas mesmas letras, nas colunas, não diferem significativamente. Comparações entre o controle e os tratamentos do mesmo nutriente.

O tratamento com maior teor de Ca na solução nutritiva também produziu mais material seco total, porém, devido ao aumento da massa das raízes. A massa de material seco da parte aérea não foi alterado pela variação no teor do nutriente na solução nutritiva.

As doses maiores de $\mathrm{K}$ e $\mathrm{Mg}$ da solução, mostraram um efeito significativo e negativo sobre a produção de massa de material seco das raízes, em relação ao controle ou à menor dose. A variação das doses de $\mathrm{P}$ na solução não provocou efeitos significativo na produção de massa de material seco de raízes ou da parte aérea.

Não se observou uma correlação significativa das três variáveis de produção medidas (massa de material seco das raízes, parte aérea e total) e as concentrações de nutrientes no substrato. A eq. (2) que tem o maior $\mathrm{R}^{2}$, obtido pelo método de 
incrementos de $\mathrm{R}^{2}$, não é suficiente para se considerar a produção de matéria seca total como função dos teores de nutrientes na solução, o que demonstra baixa correlação.

$$
\begin{aligned}
\mathrm{Y}= & 65,195+7,566 \times 10^{-4} \times \mathrm{N} 2-5,107 \times 10^{-4} \times \mathrm{Ca}^{2}-1,523 \times 10^{-3} \times \mathrm{NK}+ \\
& 1,33410^{-3} \times \mathrm{KCa} \\
\mathrm{R}^{2}= & 0,316
\end{aligned}
$$

Onde:

$\mathrm{Y}=$ produção de massa de material seco total em g/vaso;

$\mathrm{N}=$ Concentração de $\mathrm{N}$ na solução em $\mathrm{mg} \mathrm{L}^{-1}$;

$\mathrm{K}=$ Concentração de $\mathrm{K}$ na solução em $\mathrm{mg} \mathrm{L}^{-1}$;

$\mathrm{Ca}=$ Concentração de $\mathrm{Ca}$ na solução em $\mathrm{mg} \mathrm{L}^{-1}$.

A maior rusticidade da $M$. crispa em relação à $M$. arvensis $\mathrm{L}$, deve-se parcialmente à maior quantidade de raízes em relação à massa da parte aérea, pois como já indicou Maia (1994), essa proporção na M. arvensis L foi da ordem de 3 enquanto que na M. crispa foi de 1,3 .

\subsubsection{Número de pares de folhas}

$\mathrm{Na}$ tabela 9 , apresenta-se a evolução do número médio de pares de folhas, ficando claro o efeito positivo do $\mathrm{N}$ na solução nutritiva sobre o desenvolvimento das plantas, desde os primeiros dias de tratamento.

O efeito negativo observado no tratamento Ca400, deve-se a uma provável intoxicação por $\mathrm{Cl}$, pois as plantas dos vasos que receberam essa solução, apresentaram amarelecimento precoce, leve bronzeamento marginal e abscisão das folhas. Sintomas semelhantes aos descritos por Needham (1983) e Mengel \& Kirkby (1981) para o excesso daquele nutriente. 
Tabela 9. Número médio de pares de folhas de M. crispa por vaso, em função dos teores de nutrientes na solução nutritiva.

\begin{tabular}{lllll} 
& \multicolumn{4}{c}{ Dias após o plantio } \\
\cline { 2 - 5 } Tratamentos & 30 & 36 & 45 & 64 \\
\hline Controle & \multicolumn{3}{c}{ (número de pares de folhas/planta) } \\
\hline N105 & $35,0 \mathrm{a}^{\mathrm{y}}$ & $38,3 \mathrm{a}$ & $41,0 \mathrm{a}$ & $468,0 \mathrm{a}$ \\
N420 & $20,8 \mathrm{~b}$ & $24,3 \mathrm{~b}$ & $29,3 \mathrm{a}$ & $253,0 \mathrm{a}$ \\
P15,5 & $60,3 \mathrm{c}$ & $61,3 \mathrm{a}$ & $80,3 \mathrm{~b}$ & $729,0 \mathrm{~b}$ \\
P62 & $52,0 \mathrm{~b}$ & $54,0 \mathrm{~b}$ & $69,3 \mathrm{~b}$ & $531,3 \mathrm{a}$ \\
\hline K117 & $32,0 \mathrm{a}$ & $48,0 \mathrm{a}$ & $53,8 \mathrm{a}$ & $458,8 \mathrm{a}$ \\
K468 & $33,0 \mathrm{a}$ & $36,5 \mathrm{a}$ & $42,8 \mathrm{a}$ & $451,8 \mathrm{a}$ \\
\hline Ca100 & $24,8 \mathrm{a}$ & $26,8 \mathrm{a}$ & $37,3 \mathrm{a}$ & $523,0 \mathrm{a}$ \\
Ca400 & $32,0 \mathrm{a}$ & $36,8 \mathrm{a}$ & $47,0 \mathrm{a}$ & $474,0 \mathrm{a}$ \\
\hline Mg24 & $12,8 \mathrm{~b}$ & $16,3 \mathrm{~b}$ & $21,3 \mathrm{~b}$ & $335,3 \mathrm{~b}$ \\
Mg96 & $30,3 \mathrm{a}$ & $32,8 \mathrm{a}$ & $43,0 \mathrm{a}$ & $354,8 \mathrm{a}$ \\
\hline N6m & $21,3 \mathrm{~b}$ & $24,3 \mathrm{a}$ & $35,0 \mathrm{a}$ & $458,0 \mathrm{a}$ \\
\hline
\end{tabular}

'Números seguidos pelas mesmas letras, nas colunas, não diferem significativamente. Comparações entre o controle e os tratamentos do mesmo nutriente.

Marschner (1991) afirmou que concentrações de $20 \mathrm{mM}$ de $\mathrm{Cl}$ na solução pode levar as plantas sensíveis a desenvolverem aqueles sintomas de toxidez. Como na formulação do tratamento Ca400 foram adicionados $10 \mathrm{mM} \mathrm{L}^{-1}$ de $\mathrm{Cl}$ na solução nutritiva, na forma de $\mathrm{CaCl}_{2} .2 \mathrm{H}_{2} \mathrm{O}$, concentrações semelhantes podem ter ocorrido, principalmente antes da reposição da água evapotranspirada nos tambores de solução.

Além do $\mathrm{N}$ nenhum dos demais tratamentos apresentaram diferenças significativas no numero de pares de folhas ao longo do experimento. As diferenças que surgiram nas primeiras avaliações nos tratamentos com doses mais elevadas de $\mathrm{P}$ e $\mathrm{Mg}$, 
não se sustentaram até o final do experimento, mostrando uma diferença intrínseca das plantas.

A correlação entre o número de pares de folhas, de números de dias após o plantio, a concentração de $\mathrm{N}$ e Ca na solução nutritiva, é expressa pela eq. (3).

$\mathrm{Y}=-503,555+0,465 \times \mathrm{N}-3,538 \times 10^{-4} \times \mathrm{Ca}^{2}+12,790 \times \mathrm{D}$

$\mathrm{R}^{2}=0,712$

Onde:

$\mathrm{Y}=$ Número de pares de folhas/vaso;

$\mathrm{N}=$ Concentração de $\mathrm{N}$ na solução em $\mathrm{mg} \mathrm{L}^{-1}$;

$\mathrm{Ca}=$ Concentração de Ca na solução em $\mathrm{mg} \mathrm{L}^{-1}$ :

$\mathrm{D}=$ Número de dias após o plantio.

Observou-se, que o número de dias após o plantio é o principal fator responsável pela definição do número final de pares de folhas. $\mathrm{O}$ calculo dos $\mathrm{R}^{2}$ parciais para as variáveis: números de dias após o plantio (D), $N$ na solução $(\mathrm{N})$ e o quadrado da concentração de Ca na solução $\left(\mathrm{Ca}^{2}\right)$, foram de 0,$679 ; 0,028$ e 0,004 respectivamente.

\subsubsection{Teores de nutrientes na parte aérea}

Em todos os tratamentos estudados, observou-se uma relação direta entre a concentração do nutriente na solução nutritiva e seu teor na parte aérea da planta. $\mathrm{Na}$ tabela 10, observa-se que teores dos nutrientes nas folhas sempre são significativamente elevados nos tratamentos de maior concentração do mesmo nutriente.

Esta correlação direta, entre a concentração no substrato e nos tecidos vegetais, é observada por diversos autores (Marschener, 1991; Mengel, 1981; Raij, 1981; 
Malavolta, 1980). Os efeitos das absorções dos nutrientes e suas relações com os demais serão discutidos nos próximos itens.

Tabela 10. Teores de macronutrienes na massa de material seco da parte aérea de $M$. crispa, em função dos teores de nutrientes na solução nutritiva.

\begin{tabular}{|c|c|c|c|c|c|c|}
\hline \multirow[b]{2}{*}{ Tratamentos } & \multicolumn{6}{|c|}{ Teores de nutriente na parte aérea $\left(\mathrm{g} \mathrm{kg}^{-1}\right)$} \\
\hline & $\mathrm{N}$ & $\mathrm{P}$ & $\mathrm{K}$ & $\mathrm{Ca}$ & $\mathrm{Mg}$ & S \\
\hline Controle & $23,05 \mathrm{a}^{1}$ & $2,38 \mathrm{a}$ & $19,18 \mathrm{a}$ & $17,98 \mathrm{a}$ & $4,83 a$ & $2,48 \mathrm{a}$ \\
\hline N105 & $16,63 b$ & $2,95 b$ & $24,68 b$ & $16,25 a$ & $4,45 a$ & $2,15 \mathrm{ab}$ \\
\hline N420 & $28,18 c$ & $3,33 b$ & $16,95 \mathrm{c}$ & $18,50 \mathrm{a}$ & $3,73 b$ & $1,85 b$ \\
\hline $\mathrm{P} 15,5$ & $25,51 \mathrm{a}$ & $2,03 a$ & $21,05 \mathrm{ab}$ & $20,53 a$ & $5,38 b$ & $1,63 b$ \\
\hline P62 & $16,30 b$ & $3,45 b$ & $17,18 \mathrm{ac}$ & $20,48 a$ & $3,90 \mathrm{c}$ & $1,60 \mathrm{~b}$ \\
\hline K117 & $19,39 b$ & $3,10 b$ & $8,80 \mathrm{~b}$ & $18,85 a$ & $6,60 \mathrm{~b}$ & $1,98 b$ \\
\hline K468 & $25,61 \mathrm{a}$ & $3,08 \mathrm{~b}$ & $33,45 c$ & $17,60 \mathrm{a}$ & $4,68 \mathrm{a}$ & $2,23 b$ \\
\hline $\mathrm{Ca} 100$ & $18,25 b$ & $2,80 \mathrm{~b}$ & $19,40 a$ & $14,30 \mathrm{~b}$ & $3,90 \mathrm{~b}$ & $1,95 b$ \\
\hline $\mathrm{Ca} 400$ & $32,54 c$ & $2,73 \mathrm{ab}$ & $34,70 b$ & $24,08 c$ & $5,80 \mathrm{c}$ & $2,10 \mathrm{~b}$ \\
\hline $\mathrm{Mg} 24$ & $23,63 a$ & $3,70 \mathrm{~b}$ & $22,38 b$ & $22,78 b$ & $3,10 \mathrm{~b}$ & $1,60 \mathrm{~b}$ \\
\hline Mg96 & $28,33 b$ & $3,15 \mathrm{c}$ & $25,63 c$ & $15,93 a$ & $7,30 \mathrm{c}$ & $2,08 \mathrm{c}$ \\
\hline
\end{tabular}

Números seguidos pelas mesmas letras, nas colunas, não diferem significativamente.

Comparações entre o controle e os tratamentos do mesmo nutriente.

As soluções de todos os tratamentos receberam doses idênticas de micronutrientes, porém como pode-se observar na tabela 11, ocorreram diferenças significativas nos teores desses nutrientes nas folhas. A maioria dos teores de $\mathrm{Zn}$ encontrados na parte aérea foi superior ao nível tóxico de $46 \mathrm{mg} \mathrm{kg}^{-1}$ definido por Misra (1995), porém não se observou os sintomas de toxidez que descreveu: clorose internerval moderada nas folhas em desenvolvimento e avermelhamento generalizado das nervuras no terço superior das folhas. 
Tabela 11. Teores de micronutrientes na massa de material seco da parte aérea de $M$. crispa, em função dos teores de nutrientes na solução nutritiva.

\begin{tabular}{lccccc}
\hline \multirow{2}{*}{ Tratamentos } & \multicolumn{5}{c}{ Teores de nutriente nas parte aérea $\left(\mathrm{mg} \mathrm{kg}^{-1}\right)$} \\
\cline { 2 - 6 } Controle & $\mathrm{Fe}$ & $\mathrm{Zn}$ & $\mathrm{Mn}$ & $\mathrm{B}$ & $\mathrm{Cu}$ \\
\cline { 2 - 6 } N105 & $220,5 \mathrm{a}$ & $45,00 \mathrm{a}$ & $38,75 \mathrm{a}$ & $42,50 \mathrm{a}$ & $3,25 \mathrm{a}$ \\
\hline N420 & $201,50 \mathrm{a}$ & $29,50 \mathrm{~b}$ & $63,60 \mathrm{~b}$ & $26,94 \mathrm{~b}$ & $37,75 \mathrm{~b}$ \\
\hline P15,5 & $233,50 \mathrm{a}$ & $64,00 \mathrm{c}$ & $63,25 \mathrm{~b}$ & $34,91 \mathrm{c}$ & $7,50 \mathrm{a}$ \\
\hline P62 & $266,50 \mathrm{a}$ & $49,00 \mathrm{a}$ & $54,50 \mathrm{~b}$ & $34,36 \mathrm{~b}$ & $4,25 \mathrm{a}$ \\
\hline K117 & $171,5 \mathrm{~b}$ & $42,25 \mathrm{a}$ & $31,75 \mathrm{a}$ & $31,43 \mathrm{~b}$ & $8,50 \mathrm{a}$ \\
K468 & $244,25 \mathrm{a}$ & $46,50 \mathrm{a}$ & $45,50 \mathrm{a}$ & $48,91 \mathrm{~b}$ & $3,00 \mathrm{a}$ \\
\hline Ca100 & $259,75 \mathrm{a}$ & $44,00 \mathrm{a}$ & $44,00 \mathrm{a}$ & $28,38 \mathrm{c}$ & $17,25 \mathrm{~b}$ \\
Ca400 & $225,75 \mathrm{a}$ & $56,75 \mathrm{ab}$ & $74,50 \mathrm{~b}$ & $34,42 \mathrm{~b}$ & $3,25 \mathrm{~b}$ \\
\hline Mg24 & $293,00 \mathrm{~b}$ & $63,00 \mathrm{~b}$ & $52,00 \mathrm{c}$ & $25,63 \mathrm{c}$ & $38,50 \mathrm{~b}$ \\
\hline Mg96 & $304,00 \mathrm{~b}$ & $66,00 \mathrm{~b}$ & $67,75 \mathrm{~b}$ & $30,89 \mathrm{~b}$ & $52,50 \mathrm{~b}$ \\
\hline
\end{tabular}

Números seguidos pelas mesmas letras, nas colunas, não diferem significativamente. Comparações entre o controle e os tratamentos do mesmo nutriente.

\subsubsection{Efeito das doses de $\mathbf{N}$ nos teores de nutrientes na parte aérea}

$\mathrm{O}$ aumento no teor de $\mathrm{N}$ nas folhas foi proporcional ao aumento do nutriente na solução, conforme observa-se na tabela 10 , mostrando um efeito direto da absorção por fluxo de massa, conforme citam Epstein (1975) e Malavolta (1980).

Segundo a teoria desenvolvida por Agren (1985), concentrações mais elevadas de $\mathrm{N}$ nos tecidos alteram a relação entre a massa de raízes e da parte aérea das plantas. Neste experimento, obteve-se relações de 2,25; 0,81 e 0,99 nos tratamentos N105, controle (N210) e N420, calculadas com os valores da tabela 8, para os respectivos teores de 16,63, 23,05 e 28,18 $\mathrm{g} \mathrm{kg}^{-1}$ de massa de folhas secas (Tabela 10). 
Essas relações são coerentes ao modelo desenvolvido por Levin et al.(1989), o qual mostra que essa relação tende a ser assintótica, conforme os teores do nutriente nos tecidos tornam-se elevados, sendo a convergência para o limite assintótico muito rápido. Nesse caso, os teores de 16,63 e 23,05 $\mathrm{g} \mathrm{kg}^{-1}$ de $\mathrm{N}$ na parte aérea dos tratamentos $\mathrm{N} 105 \mathrm{e}$ N210 (controle), mostram, segundo o modelo de Agren \& Ingrestad (1987), que estão próximos da maior taxa de fotossíntese por unidade de massa e da maior produção.

Pode-se inferir, dessa forma, que soluções nutritivas com concentrações próximas de $420 \mathrm{mg} \mathrm{L}^{-1}$ de $\mathrm{N}$ já proporcionariam um rendimento máximo.

Os teores maiores de $\mathrm{K}$ e $\mathrm{Mg}$ nos tecidos da parte aérea nas soluções mais pobres em $\mathrm{N}$ repetem os resultados apresentados por Jones et al.(1991). Segundo esse autor, a presença de $\mathrm{N}$ nítrico favorece a absorção de cátions $\left(\mathrm{K}^{+} \mathrm{e} \mathrm{Mg}^{+2}\right)$, corroborando com a menor concentração desses dois cátions no tratamento N420, onde teriam sido menos absorvidos devido ao $\mathrm{N}$ amoniacal contido no $\mathrm{NH}_{4} \mathrm{NO}_{3}$, representando $12,5 \%$ do $\mathrm{N}$ total, utilizado para aumentar a concentração do nutriente na solução.

$\mathrm{O}$ aumento da concentração de $\mathrm{N}$ na solução do tratamento $\mathrm{N} 420$ foi conseguido utilizando-se 7,5 $\mathrm{mM} \mathrm{L}^{-1}$ de $\mathrm{NH}_{4} \mathrm{NO}_{3}$. A introdução da forma amoniacal no sistema foi responsável pelo abaixamento do $\mathrm{pH}$ da solução. Esses $7,5 \mathrm{mM} \mathrm{L}^{1}$ utilizados representaram $105 \mathrm{mg} \mathrm{L}^{-1}$ de $\mathrm{N}$ na forma amoniacal, no total de $420 \mathrm{mg} \mathrm{L}^{-1}$ de $\mathrm{N}$ do tratamento, deixando a relação entre o $\mathrm{N}$ nítrico e o $\mathrm{N}$ amoniacal da ordem de 3:1.

Porém no mesmo trabalho (Jones et al., 1991), em um estudo com rabanete (Raphanus sativus L.), mostra que na relação 3:1, as absorções e o acúmulo nas folhas de outros nutrientes são afetados mais pelo $\mathrm{pH}$ da solução do que pela competição eventual do $\mathrm{N}$ amoniacal presente no meio. Seus resultados são semelhantes aos obtidos por este trabalho, quanto à diminuição dos teores de $\mathrm{K}$ e $\mathrm{Mg}$ e o aumento do $\mathrm{Zn}$ nas folhas, como pode ser observado nas tabelas 10 e 11 , indicando que as diferenças significativas deveram-se, principalmente, ao $\mathrm{pH}$ baixo. Já os teores menores de $\mathrm{S}$ (Tabela 10), B (Tabela 11), deveu-se principalmente à maior disponibilidade de $\mathrm{N}$ na solução, independentemente da forma (id. ibid. ). 
O teor elevado de $\mathrm{Cu}$, observado nos tecidos da parte aérea das plantas que receberam a solução do tratamento $\mathrm{Nl} 05$, que pode ser observado na tabela 11, é antagônico ao apresentado por Malavolta (1980), que apresenta uma relação direta e inversa entre a disponibilidade de $\mathrm{Cu}$ e o pH do meio. Ferreira \& Cruz (1991), porém, mostram que a relação maior raízes / parte aérea nos vasos daquele tratamento, possibilitou a formação proporcional maior de exudados radiculares, que por sua vez puderam quelatar o metal, uma outra forma, além da iônica $\left(\mathrm{Cu}^{+2}\right)$, que também pode ser absorvida pelas plantas (Dechen et al.,1991). Kabata-Pendias \& Pendias (1985), apresentam um efeito antagônico entre o $\mathrm{Cu}$ e o $\mathrm{Zn}$, o que também ajuda na explicação do teor alto observado no tratamento $\mathrm{N} 105$.

O estudo das regressões pelo método "stepwise" mostra que o teor de $\mathrm{N}$ nas folhas é uma funçãorepresentada pela eq. (4).

$$
\begin{aligned}
\mathrm{Y}= & 17,849-5,75 \times 10^{-2} \times \mathrm{Ca}-1,21 \times 10^{-4} \times \mathrm{N}^{2}-2,43 \times 10^{-3} \times \mathrm{P}^{2}+ \\
& 5,00 \times 10^{-4} \times \mathrm{NCa}+3,60 \times 10^{-4} \times \mathrm{Mg} \\
\mathrm{R}^{2}= & 0,720
\end{aligned}
$$

Onde:

$\mathrm{Y}=$ Teor de $\mathrm{N}$ na parte aérea em $\mathrm{g} \mathrm{kg}^{-1}$;

$\mathrm{Ca}=$ Concentração de Ca na solução em $\mathrm{mg} \mathrm{L}^{-1}$;

$\mathrm{N}=$ Concentração de $\mathrm{N}$ na solução em $\mathrm{mg} \mathrm{L}^{-1}$;

$\mathrm{P}=$ Concentração de $\mathrm{P}$ na solução em $\mathrm{mg} \mathrm{L}^{-1}$;

$\mathrm{Mg}=$ Concentração de $\mathrm{Mg}$ na solução em $\mathrm{mg} \mathrm{L}^{-1}$.

Os $R^{2}$ parciais da eq. (4) foram 0,$438 ; 0,132 ; 0,109 ; 0,025$ e 0,016 para os efeitos $\mathrm{NCa}, \mathrm{P}^{2}, \mathrm{KMg}, \mathrm{N}^{2}$ e $\mathrm{Ca}$, respectivamente, mostrando a importância, principalmente do $\mathrm{Ca}$, cuja interação com a concentração de $\mathrm{N}$ na solução explicou mais de $44 \%$ do $\mathrm{N}$ nos tecidos da parte aérea.. 


\subsubsection{Efeito das doses de $P$ nos teores de nutrientes na parte aérea}

A concentração maior de $\mathrm{P}$ na solução do tratamento P62, causou um aumento significativo do nutriente nos tecidos da parte aérea (Tabela 10). As relações entre a massa das raizes e a massa de parte aérea, calculadas a partir dos resultados da tabela 8 , foram de 0,$88 ; 0,81$ e 0,69 , nos tratamentos P15,5; P31 (controle) e P62 respectivamente, mostrando que as menores doses de $\mathrm{P}$ inibem muito menos $\mathrm{o}$ desenvolvimento das raizes do que o desenvolvimento da parte aérea, conforme observa Marschener (1995) com dados obtidos em experimento com feijoeiro (Phaseolus vulgaris).

Os teores de $\mathrm{P}$ nos tecidos da parte aérea, observados em todos os tratamentos (Tabela 10), situam-se dentro da normalidade para a maioria das culturas, entre 1 e $10 \mathrm{~g}$ $\mathrm{kg}^{-1}$, segundo Jones et al. (1991). Já a relação normal entre os teores de N e P nos tecidos, usada como um parâmetro de DRIS, por refletirem o metabolismo e a partição dos carboidratos entre as partes da planta, está entre 3 e 1 (id. ibid.). Neste trabalho, essa relação foi de 6 até 10 , devido às altas concentrações de $N$ na planta. Porém observou-se uma queda abrupta da relação N:P entre os tratamentos P3 1 (controle) e P62; de 9,7 e 4,7 , respectivamente, mostrando que as melhores concentrações de $\mathrm{P}$ na solução estariam entre esses dois tratamentos.

$\mathrm{O}$ antagonismo entre $\mathrm{P}$ e $\mathrm{Mg}$, já observado em várias espécies e descrito, em folhas de espinafre e tomate, por Jones et al. (1991) foi bastante evidente neste trabalho, onde os teores de $\mathrm{Mg}$ foram 5,38; 4,83 e 3,90 $\mathrm{g} \mathrm{kg}^{-1}$ nos tratamentos P15,5, P31 (controle) e P62, respectivamente.

$\mathrm{O}$ aumento das doses de $\mathrm{P}$ na solução afetaram de forma significativa e negativa os teores dos micronutrientes Fe e Mn (Tabela 11), conforme já observado por outros autores (Jones et al., 1991). 


\subsubsection{Efeito das doses de $\mathrm{K}$ nos teores de nutrientes na parte aérea}

Observou-se que o aumento do teor de $\mathrm{K}$ na solução nutritiva aumentou significativamente o teor do elemento na parte aérea da planta. O estudo das regressões mostrou que o teor de $\mathrm{K}$ na parte aérea é função das concentrações do $\mathrm{KCa}, \mathrm{NP}$ e $\mathrm{KMg}$, na solução, cujos $R^{2}$ parciais foram de 0,$733 ; 0,067$ e 0,038 , respectivamente. A eq. (5) mostra essas relações.

$$
\begin{aligned}
\mathrm{Y} & =1,026-6,00 \times 10^{-5} \times \mathrm{NP}+2,51 \times 10^{-5} \times \mathrm{KCa}+3,06 \times 10^{-5} \times \mathrm{KMg} \\
\mathrm{R}^{2} & =0,838
\end{aligned}
$$

Onde:

$\mathrm{Y}=$ Teor de $\mathrm{K}$ na parte aérea em $\mathrm{g} \mathrm{kg}^{-1}$;

$\mathrm{N}=$ Concentração de $\mathrm{N}$ na solução em $\mathrm{mg} \mathrm{L}^{-1}$;

$\mathrm{P}=$ Concentração de $\mathrm{P}$ na solução em $\mathrm{mg} \mathrm{L}^{-1}$;

$\mathrm{K}=$ Concentração de $\mathrm{K}$ na solução em $\mathrm{mg} \mathrm{L}^{-1}$;

$\mathrm{Ca}=$ Concentração de Ca na solução em $\mathrm{mg} \mathrm{L}^{-1}$;

$\mathrm{Mg}=$ Concentração de $\mathrm{Mg}$ na solução em $\mathrm{mg} \mathrm{L}^{-1}$.

O aumento do teor de $\mathrm{N}$ na parte aérea, quando se aumentou a concentração do $\mathrm{K}$ na solução, mostrou a interação discutida entre os dois nutrientes por Jones et al. (1991) e Marschner (1995). A literatura mostra que o teor de $\mathrm{N}$ nas folhas aumenta conforme o teor de $\mathrm{K}$ aumenta, ou diminui até $20 \mathrm{~g} \mathrm{~kg}^{-1}$ de massa de material seco de folhas de cana-de-açúcar, o que seria um valor crítico para o $\mathrm{K}$.

A inibição competitiva, clássica segundo Malavolta (1980), do K sobre a concentração do $\mathrm{Mg}$, é observada em diversas espécies de plantas por Jones et al. (1991). Neste trabalho também ocorreu de modo significativo, conforme é observado na tabela 10 , onde o teor de $\mathrm{Mg}$ de $4,83 \mathrm{~g} \mathrm{~kg}^{-1}$ passa para $6,60 \mathrm{~g} \mathrm{~kg}^{-1}$ quando a concentração da solução diminui de $234 \mathrm{mg} \mathrm{L}^{-1}$ (controle), para $117 \mathrm{mg} \mathrm{L}^{-1}$ do tratamento $\mathrm{K} 117$. 
O aumento significativo no teor de $\mathrm{Mg}$, que ocorreu no tratamento $\mathrm{K} 117$, que era o mais pobre em $\mathrm{K}^{+}$, é descrito por Mengel \& Kirkby (1982) como um exemplo de antagonismo, indicando uma concentração de $\mathrm{K}$ na solução, abaixo do suficiente. Segundo o mesmo autor, o teor alto de $\mathrm{Mg}$ não pode ser explicado simplesmente em termos do efeito da concentração, resultado de uma pequena taxa de crescimento, que não se observou neste trabalho, conforme pode ser observado na tabela 8 , mas provavelmente deve ter sido originado de um aumento efetivo da absorção de $\mathrm{Mg}$ em soluções pobres em $\mathrm{K}$. Os autores apresentam teores de $\mathrm{Mg}$ em folhas de tomateiro, em função da concentração de $\mathrm{K}$ na solução com comportamento idêntico ao observado na tabela 8 .

Um aumento indiscriminado da concentração de $\mathrm{K}$ na solução poderá levar a prejuízos na produção, devido à indução de uma defíciência de $\mathrm{Mg}$, comprometendo as funções essenciais do nutriente, como a fotossintese, síntese de clorofila, proteínas e ativação de diversos processos enzimáticos (Mengel \& Kirkby, 1982; Marschener, 1995).

Assim, como foi reportado em algodão, amendoim e soja (Jones et al., 1991), o aumento do $\mathrm{K}$ disponível no substrato diminuiu significativamente os teores de $\mathrm{B}$ encontrados nos tecidos da parte aérea da planta, conforme pode ser observado na tabela 11. O autor recomenda que o fornecimento de doses elevadas de $\mathrm{K}$ sejam acompanhados de uma correção adequada do $\mathrm{B}$ disponivel, pois os teores altos do primeiro nutriente tendem a aumentar os efeitos negativos da deficiência de $B$, como o transporte de carboidratos, por exemplo (Malavolta, 1980).

Apesar do decréscimo significativo no teor de B no tratamento com menor concentração de $\mathrm{K}^{+}$observado na tabela 11 , não foram observados no tratamento (K117), os sintomas típicos da deficiência do micronutriente (B), como a clorose na base, menor tamanho e deformação das folhas mais novas, acompanhada, ou não de morte da gema apical e encurtamento dos internódios (Carmello \& Rossi, 1997).

$\mathrm{O}$ aumento de mais de 5 vezes no teor de $\mathrm{Cu}$, nos tecidos da parte aérea da planta (Tabela 11), que ocorreu no tratamento $K 468$, o mais rico em $K$, não chegou a ser 
prejudicial à planta. Segundo Marschner (1995), os valores críticos em plantas sensíveis, as concentrações elevadas do elemento situam-se ao redor de $14 \mathrm{mg} \mathrm{kg}^{-1}$ nas folhas, porém Bataglia (1991) e Jones et al.(1991) colocam este valor entre 20 e $20-30 \mathrm{mg} \mathrm{kg}^{-1}$ respectivamente, ou seja, o valor de $17,25 \mathrm{mg} \mathrm{kg}^{-1}$ encontra-se ainda num nível adequado.

\subsubsection{Efeito das doses de Ca nos teores de nutrientes na parte aérea}

O acréscimo do Ca na solução nutritiva alterou significativamente os teores de $\mathrm{N}, \mathrm{K}, \mathrm{Mg}$ e do próprio Ca nos tecidos da parte aérea (Tabela 10). Observou-se um aumento do Ca nos tecidos à medida que se aumentava a concentração do nutriente no substrato, com uma variação aproximadamente linear, conforme foi descrito por Jones et al.(1991).

$\mathrm{O}$ aumento no teor de $\mathrm{N}$ dos tecidos das plantas com mais $\mathrm{Ca}$ disponível não foi observado por outros autores na literatura especializada. Neste trabalho, o maior teor de $\mathrm{N}$ na planta ocorreu no tratamento Ca400, o mais rico em Ca do experimento. Porém a concentração alta de $\mathrm{N}$ na parte aérea, não correspondeu um aumento significativo na produção de folhas na tabela 8 , onde observa-se um aumento de $53 \%$ na massa de material seco das raizes, que resultou num aumento da massa total da planta. No entanto, nota-se na tabela 9, que o número de folhas do tratamento Ca400 foi significativamente menor do que nos tratamentos Ca100 e Ca200 (controle), deixando evidente, uma maior densidade da parte aérea das plantas.

O antagonismo Ca Mg, discutido por Jo nes et al. (1991) e Malavolta (1980), não foi observado. Na tabela 10 , observa-se que o teor de $\mathrm{Mg}$ nos tecidos das plantas do tratamento Ca400 foi um dos maiores de todo o experimento. Essa alta concentração deveu-se, principalmente, ao pH médio da solução de 6,44 (Tabela 6), que disponibilizou o nutriente, conforme foi citado por Tisdale et al.(1993) e Mengel (1982). 
Segundo Jones et al. (1991), o aumento na concentração de Ca pode diminuir o

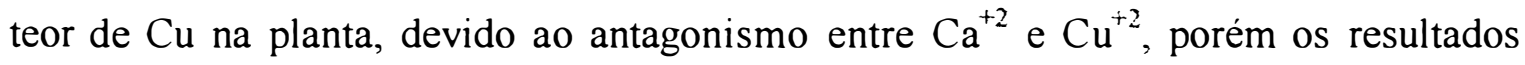
obtidos neste trabalho não o confirmam, conforme mostra a tabela 11 , onde o tratamento

Ca400 tem 38,50 $\mathrm{mg} \mathrm{kg}^{-1}$ de Cu na massa de material seco da parte aérea. Cabem aqui as mesmas explicações dadas para o aumento do teor de $\mathrm{Cu}$ na parte aérea, no item 4.2.3.1., sobre o efeito das doses de $\mathrm{N}$ nos teores de nutrientes da parte aérea.

$\mathrm{O}$ teor elevado de $\mathrm{Cu}$ nos tecidos da parte aérea, observado no tratamento Ca400 (Tabela 11), está dentro do nivel toxico definido por vários autores (Bataglia, 1991), Jones et al. (1991), porém não se observou naquele tratamento, os sintomas típicos de toxidez do elemento, tais como pequeno desenvolvimento radicular, clorose que se desenvolve da base para a ponta ao longo da nervura central e queda das folhas (Dechen et al., 1991). Essa falta de sintoma, deveu-se ao alto teor de $\mathrm{Ca}^{+2}$ no tratamento, que pode diminuir os efeitos da toxidez, que são originados de danos na permeabilidade da membrana (Malavolta, 1980).

\subsubsection{Efeito das doses de $\mathrm{Mg}$ nos teores de nutrientes na parte aérea}

Os teores de $\mathrm{Mg}$ deste trabalho encontram-se dentro dos limites normais, entre 2 e $10 \mathrm{~g} \mathrm{~kg}^{-1} \mathrm{de} \mathrm{Mg}$ na massa de folhas secas, apresentados por vários autores (Marschner, 1995; Jones et al., 1991; Mengel \& Kirkby, 1982).

A concentração maior de $\mathrm{Ca}$ nos tecidos da parte aérea do tratamento $\mathrm{Mg} 24$, se deve à disponibilidade de sítios de absorção não ocupados pelo $\mathrm{Mg}$, que estava em concentração muito baixa neste tratamento (Malavolta, 1998). Pelo mesmo motivo, observa-se um efeito negativo da concentração do $\mathrm{Mg}$ na solução sobre os teores dos micronutrientes $\mathrm{Fe}, \mathrm{Mn}, \mathrm{Cu}$ e $\mathrm{Zn}$ da parte aérea (id. ibid.), conforme se observa na tabela 11.

$\mathrm{O}$ estudo da regressão mostrou que a interação $\mathrm{CaMg}$ e o $\mathrm{K}$ na solução nutritiva, foram as principais responsáveis pelo teor de $\mathrm{Mg}$ na folha, conforme descreve a 
literatura (Marschner, 1995; Jones et al., 1991; Mengel \& Kirkby, 1982; Malavolta, 1980). Os $R^{2}$ parciais da interação CaMg e do efeito do $K$ foram de 0,542 e 0,159 respectivamente. A eq. (6) mostra o efeito de todas variáveis selecionadas pelo procedimento "stepwise".

$$
\begin{aligned}
\mathrm{Y}= & 0,793+2,638 \times 10^{-5} \times \mathrm{CaMg}-1,587 \times 10^{-1} \times \mathrm{K}+4,776 \times 10^{-5} \times \mathrm{PK}- \\
& 1,66 \times 10^{-6} \times \mathrm{NCa}+5,74 \times 10^{-6} \times \mathrm{K}^{2}+1,033 \times 10^{-4} \times \mathrm{P}^{2} \\
\mathrm{R}^{2}= & 0,910
\end{aligned}
$$

Onde:

$\mathrm{Y}=$ Teor de $\mathrm{Mg}$ na parte aérea em $\mathrm{g} \mathrm{kg}^{-1}$;

$\mathrm{Ca}=$ Concentração de $\mathrm{Ca}$ na solução em $\mathrm{mg} \mathrm{L}^{-1}$;

$\mathrm{Mg}=$ Concentração de $\mathrm{Mg}$ na solução em $\mathrm{mg} \mathrm{L}^{-1}$;

$\mathrm{K}=$ Concentração de $\mathrm{K}$ na solução em $\mathrm{mg} \mathrm{L}^{-1}$;

$\mathrm{P}=$ Concentração de $\mathrm{P}$ na solução em $\mathrm{mg} \mathrm{L}^{-1}$;

$\mathrm{N}=$ Concentração de $\mathrm{N}$ na solução em $\mathrm{mg} \mathrm{L}^{-1}$.

\subsubsection{Teores de nutrientes nas raízes}

$\mathrm{Na}$ tabela 12, são apresentados os teores de nutrientes observados nas raízes, onde nota-se que, com exceção do $\mathrm{P}$, os teores dos demais macronutrientes são muito menores nas raízes, cerca da metade, do observado na parte aérea em todos os tratamentos. De um modo geral, o comportamento do teor de nutrientes nas raízes foram semelhantes aos das folhas.

Apesar de todos os tratamentos terem recebido soluções com a mesma quantidade de micronutrientes, houve diferenças significativas, determinadas nas raízes, mostrando que ocorreu correlações entre as concentrações dos macronutrientes no 
substrato e a absorção de micronutrientes (Malavolta, 1980; Marschner, 1995). Na tabela 13 são apresentados os resultados dos teores de micronutrientes nas raízes.

Tabela 12. Teores de macronutrienes nas raízes de M. crispa, em função dos teores de nutrientes na solução nutritiva.

\begin{tabular}{lccccccc}
\hline & \multicolumn{6}{c}{ Teores de nutriente nas raízes $\left(\mathrm{g} \mathrm{kg}^{-1}\right)$} \\
\cline { 4 - 8 } Tratamentos & & $\mathrm{N}$ & $\mathrm{P}$ & $\mathrm{K}$ & $\mathrm{Ca}$ & $\mathrm{Mg}$ & $\mathrm{S}$ \\
\cline { 5 - 9 } Controle & & $12,01 \mathrm{a}$ & $2,13 \mathrm{a}$ & $19,13 \mathrm{a}$ & $11,73 \mathrm{a}$ & $5,53 \mathrm{a}$ & $1,15 \mathrm{a}$ \\
\hline N105 & & $6,50 \mathrm{~b}$ & $2,48 \mathrm{a}$ & $16,08 \mathrm{a}$ & $5,00 \mathrm{~b}$ & $2,80 \mathrm{~b}$ & $1,20 \mathrm{a}$ \\
N420 & & $10,28 \mathrm{a}$ & $1,35 \mathrm{~b}$ & $7,68 \mathrm{~b}$ & $13,88 \mathrm{c}$ & $2,20 \mathrm{~b}$ & $4,48 \mathrm{~b}$ \\
\hline P15,5 & & $12,39 \mathrm{a}$ & $1,45 \mathrm{~b}$ & $19,15 \mathrm{a}$ & $9,08 \mathrm{c}$ & $4,60 \mathrm{~b}$ & $1,05 \mathrm{a}$ \\
P62 & & $6,60 \mathrm{~b}$ & $3,13 \mathrm{c}$ & $9,70 \mathrm{~b}$ & $14,65 \mathrm{~b}$ & $3,73 \mathrm{c}$ & $0,93 \mathrm{a}$ \\
\hline K117 & $8,22 \mathrm{~b}$ & $1,65 \mathrm{~b}$ & $7,30 \mathrm{~b}$ & $7,70 \mathrm{~b}$ & $3,53 \mathrm{~b}$ & $0,60 \mathrm{a}$ \\
K468 & $12,41 \mathrm{a}$ & $2,58 \mathrm{c}$ & $28,08 \mathrm{c}$ & $10,20 \mathrm{c}$ & $3,03 \mathrm{~b}$ & $1,00 \mathrm{a}$ \\
\hline Ca100 & $9,77 \mathrm{~b}$ & $2,08 \mathrm{a}$ & $9,95 \mathrm{~b}$ & $4,88 \mathrm{~b}$ & $2,50 \mathrm{~b}$ & $0,58 \mathrm{a}$ \\
Ca400 & $13,61 \mathrm{a}$ & $2,00 \mathrm{a}$ & $19,50 \mathrm{a}$ & $7,43 \mathrm{c}$ & $3,40 \mathrm{c}$ & $0,93 \mathrm{a}$ \\
\hline Mg24 & $9,42 \mathrm{~b}$ & $2,03 \mathrm{a}$ & $11,85 \mathrm{~b}$ & $5,53 \mathrm{~b}$ & $2,55 \mathrm{~b}$ & $1,53 \mathrm{a}$ \\
Mg96 & $9,49 \mathrm{~b}$ & $1,88 \mathrm{a}$ & $14,50 \mathrm{~b}$ & $6,58 \mathrm{~b}$ & $5,88 \mathrm{a}$ & $0,63 \mathrm{a}$ \\
\hline
\end{tabular}

Números seguidos pelas mesmas letras, nas colunas, não diferem significativamente. Comparações entre o controle e os tratamentos do mesmo nutriente.

Os teores de $\mathrm{Fe}$ nas raízes (Tabela 13) são os que mais se destacam quando comparados aos das folhas (Tabela 11). Os teores do nutriente nas raizes foram maiores de 3 a 7 vezes o das folhas, mostrando que os maiores teores de $\mathrm{Fe}$ nas raizes não dependeram do tratamento que receberam. Já o teor de $\mathrm{Zn}$ nas raizes são menores do que os nas folhas, indicando ser nesta parte da planta onde ocorrem a maioria das reações enzimáticas intermediadas pelo elemento (Malavolta, 1980).

$\mathrm{O}$ teor baixo de Fe nas raízes das plantas tratadas com a solução onde se aplicou metade da concentração de $\mathrm{Ca}$ ( $\mathrm{Ca} 100)$, foi a metade do teor de Fe do controle (Ca200), 
mostrando uma relação direta entre os dois nutrientes. Os teores de Fe nas folhas, porém, não apresentaram o mesmo efeito. No trabalho de Jones et al.(1991) foi necessário que a concentração de $\mathrm{Ca}$ fosse de 1/50 da normal, ou omissão total do macronutriente na solução, para que se observasse uma diminuição significativa no teor de Fe nas folhas de milho.

Os valores baixos do $\mathrm{pH}$, que segundo Malavolta (1980), colocaria uma maior quantidade de Fe disponível para a planta, não se evidenciaram neste trabalho. As raízes dos tratamentos com pH abaixo de 5,00, N420 e Ca100, apresentaram teores idênticos ou significativamente mais baixos que o controle, respectivamente. Os resultados deste trabalho mostram que a absorção de Fe pelas raizes da $M$. crispa foi muito mais sensiveis à falta de $\mathrm{Ca}$ do que ao $\mathrm{pH}$.

Tabela 13. Teores de micronutrientes nas raízes de M. crispa, em função dos teores de nutrientes na solução nutritiva.

\begin{tabular}{|c|c|c|c|c|c|}
\hline \multirow[b]{2}{*}{ Tratamentos } & \multicolumn{5}{|c|}{ Teores de nutriente nas raízes $\left(\mathrm{mg} \mathrm{kg}^{-1}\right)$} \\
\hline & $\mathrm{Fe}$ & $\mathrm{Zn}$ & $\mathrm{Mn}$ & $\mathrm{B}$ & $\mathrm{Cu}$ \\
\hline Controle & $1212,50 a^{1}$ & $19,75 a$ & $36,75 a$ & $32,75 a$ & $7,75 \mathrm{a}$ \\
\hline N105 & $1046,50 \mathrm{a}$ & $19,50 \mathrm{a}$ & $34,75 a$ & $26,32 b$ & $6,50 \mathrm{a}$ \\
\hline N420 & $1490,50 \mathrm{a}$ & $52,00 \mathrm{~b}$ & $25,25 b$ & $15,37 \mathrm{c}$ & $6,75 \mathrm{a}$ \\
\hline P15,5 & $891,50 a$ & $17,50 \mathrm{a}$ & $21,50 \mathrm{~b}$ & $24,16 b$ & $7,00 \mathrm{a}$ \\
\hline P62 & $1027,25 \mathrm{a}$ & $24,00 \mathrm{~b}$ & $23,25 b$ & $22,49 b$ & $5,25 b$ \\
\hline $\mathrm{K} 117$ & $1419,50 \mathrm{a}$ & $21,00 \mathrm{a}$ & $23,75 b$ & $25,14 b$ & $6,25 b$ \\
\hline K468 & $1171,25 \mathrm{a}$ & $18,25 \mathrm{a}$ & $35,75 a$ & $32,91 \mathrm{a}$ & $6,75 b$ \\
\hline Ca100 & $604,00 b$ & $25,75 b$ & $13,75 b$ & $21,02 b$ & $9,25 b$ \\
\hline $\mathrm{Ca} 400$ & $1058,50 \mathrm{ab}$ & $17,50 \mathrm{a}$ & $30,75 \mathrm{a}$ & $25,36 b$ & $6,50 \mathrm{a}$ \\
\hline $\mathrm{Mg} 24$ & $1409,50 a$ & $19,00 \mathrm{a}$ & $30,25 a$ & $22,69 b$ & $6,75 \mathrm{ab}$ \\
\hline Mg96 & $1342,50 \mathrm{a}$ & $18,25 \mathrm{a}$ & $30,00 \mathrm{a}$ & $28,14 a$ & $6,25 b$ \\
\hline
\end{tabular}

Números seguidos pelas mesmas letras, nas colunas, não diferem significativamente. Comparações entre o controle e os tratamentos do mesmo nutriente. 


\subsubsection{Estimativa do teor de clorofila através do valor SPAD}

Os valores SPAD aumentaram à medida em que se passaram os dias após o plantio em todos os tratamentos, conforme observa-se na tabela 14. Os resultados deste trabalho, entre 20,81 e 37,00, foram mais baixos do que os observados por Campbell et al. (1990), Peng et al. (1995), Piekielek et al. (1995) e Santos (1997), que trabalharam respectivamente com Malus domestica Borkh, arroz, milho e braquiária decumbens.

Tabela 14. Estimativa do teor de clorofila nas folhas de M. crispa, através do valor SPAD, em função dos teores de nutrientes na solução nutritiva.

\begin{tabular}{lccc}
\hline \multirow{2}{*}{ Tratamentos } & \multicolumn{3}{c}{ Dias após o plantio } \\
\cline { 2 - 4 } & 6 & 36 & 65 \\
\cline { 2 - 4 } Controle & \multicolumn{3}{c}{ Valor SPAD } \\
\hline N105 & $21,92 \mathrm{a}$ & $28,38 \mathrm{a}$ & $36,75 \mathrm{a}$ \\
N420 & $24,27 \mathrm{a}$ & $33,13 \mathrm{~b}$ & $39,38 \mathrm{c}$ \\
\hline P15,5 & $21,90 \mathrm{a}$ & $29,83 \mathrm{a}$ & $36,85 \mathrm{a}$ \\
P62 & $20,55 \mathrm{a}$ & $26,88 \mathrm{a}$ & $36,43 \mathrm{a}$ \\
\hline K117 & $22,20 \mathrm{a}$ & $28,43 \mathrm{a}$ & $37,00 \mathrm{a}$ \\
K468 & $26,09 \mathrm{~b}$ & $29,20 \mathrm{a}$ & $31,25 \mathrm{a}$ \\
\hline Ca100 & $20,81 \mathrm{a}$ & $26,73 \mathrm{a}$ & $34,77 \mathrm{a}$ \\
Ca400 & $23,87 \mathrm{a}$ & $30,85 \mathrm{a}$ & $33,80 \mathrm{a}$ \\
\hline Mg24 & 23,08 & $29,88 \mathrm{a}$ & $34,45 \mathrm{a}$ \\
Mg96 & 23,64 & $29,60 \mathrm{a}$ & $34,78 \mathrm{a}$ \\
\hline
\end{tabular}

Números seguidos pelas mesmas letras, nas colunas, não diferem significativamente. Comparações entre o controle e os tratamentos do mesmo nutriente. 
O estudo das regressões do valor SPAD e teor de nutrientes nas soluções, mostrou que a eq. (7), foi a que apresentou melhores resultados, com os $R^{2}$ parciais de 0,$053 ; 0,00 ; 0,004$ e 0,7299 para $N, N^{2}, P$ e D (dias do plantio) respectivamente.

$$
\begin{aligned}
\mathrm{Y}= & 14,933+4,713 \times 10^{-2} \times \mathrm{N}-3,389 \times 10^{-2} \times \mathrm{P}-5,003 \times 10^{-5} \times \mathrm{N}^{2}+ \\
& 2,073 \times 10^{-1} \times \mathrm{D} \\
\mathrm{R}^{2}= & 0,791
\end{aligned}
$$

Onde:

$\mathrm{Y}=$ Valor SPAD;

$\mathrm{N}=$ Concentração de $\mathrm{N}$ na solução em $\mathrm{mg} \mathrm{L}^{-1}$;

$\mathrm{P}=$ Concentração de $\mathrm{P}$ na solução em $\mathrm{mg} \mathrm{L}^{-1}$;

$\mathrm{D}=$ Dias do plantio.

Os resultados obtidos confirmam as recomendações de Blackmer et al. (1993) e Santos (1997), para o uso do aparelho para avaliar o estado nutricional da planta, quanto ao nitrogênio, devido à facilidade de amostragem e correlação com o teor de clorofila das folhas.

\subsubsection{Composição do óleo essencial}

Devido ao baixo rendimento de óleo essencial da espécie, ao pequeno volume de folhas obtido, principalmente nos vasos tratados com solução mais pobre em $\mathrm{N}$ e às limitações do aparelho extrator (Moritz modificado), não foi possivel obter-se óleo, de cada um dos vasos em separado.

O pequeno volume de folhas em cada um dos vasos não foi suficiente para produzir óleo essencial o bastante para escorrer pelo funil separador, até o tubo coletor. 
O pequeno volume produzido acabava perdendo-se dentro do aparelho. Para evitar a recuperação com um solvente orgânico preferiu-se a destilação das folhas de todas as parcelas de cada tratamento ( 4 vasos) em conjunto, o que impossibilitou uma análise da variância da composição do óleo essencial, mas evitou a contaminação com substâncias estranhas ao óleo. A tabela 15 apresenta os teores das substâncias analisadas no óleo essencial, que ocorreram em concentrações superiores a $1 \%$, extraido das folhas e hastes (parte aérea) produzidas nos vasos, representando, assim como nos cromatogramas da figura 9 , os valores médios de cada tratamento.

$\mathrm{O}$ óleo das plantas cultivadas com a solução mais rica em $\mathrm{K}$ aumentou a quantidade de $\alpha$-pineno, mirceno, $\beta$-pineno e a substância não identificada (4), com tempos de retenção menores que 10 min. e diminuiu a proporção de substâncias mais pesadas: 1,8-cineol, limoneno, carvona, substância não identificada (8) e cariofileno.

Os tratamentos com menos $\mathrm{Ca}$ e $\mathrm{P}$, produziram óleos com valores bastante reduzidos em 1,8-cineol, substância que dá o aroma característico ao eucalipto, portanto esses óleos seriam úteis em composições aromáticas menos acentuadas. 

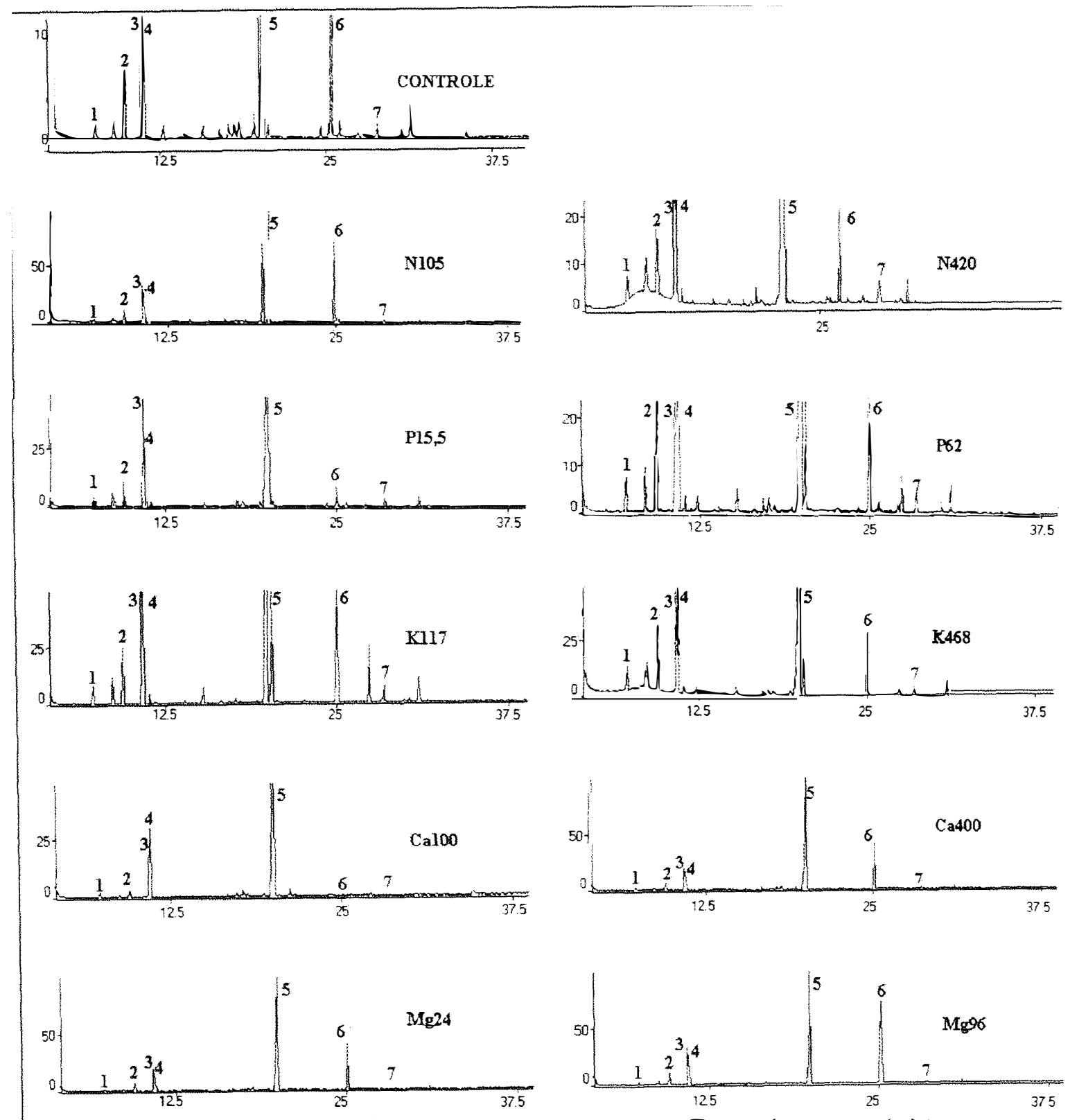

Temp de retenção (min)

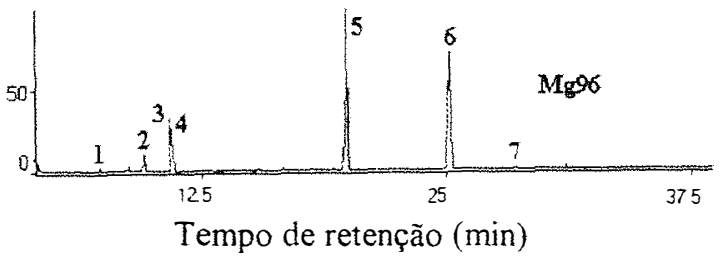

Figura 9. Cromatogramas dos óleos essenciais de $M$. crispa. cultivada em 11 soluções nutritivas. Os números próximos aos picos indicam as respectivas substâncias: $1=\beta$ pineno; 2 = não identificado I; $3=1,8$-cineol; $4=$ limoneno; $5=$ carvona; $6=$ não identificado II; 7 = cariofileno. 


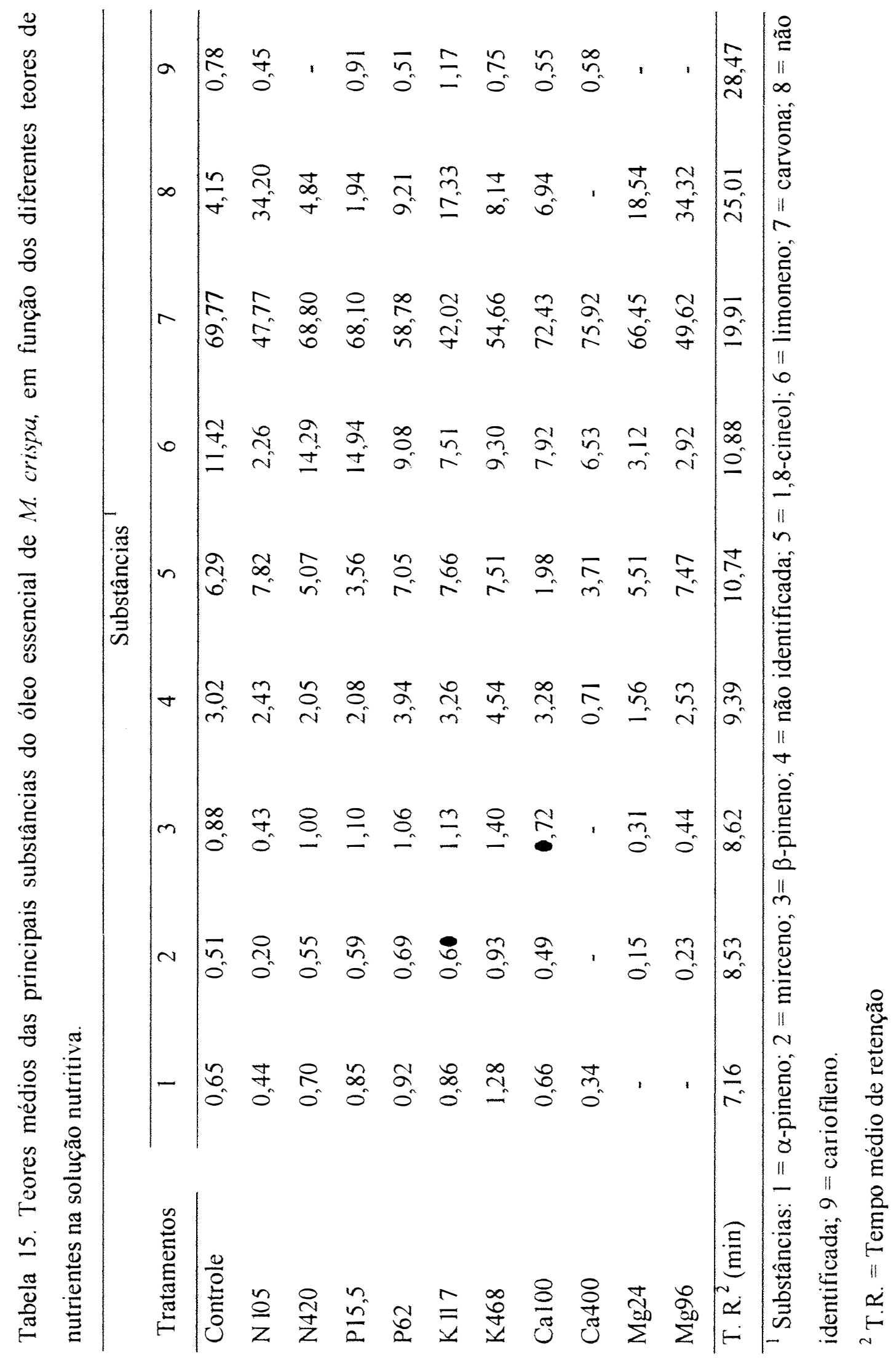




\subsubsection{Solução nutritiva recomendada}

A M. crispa é uma planta utilizada na culinária nacional como condimento fresco. Suas folhas recém colhidas são utilizadas no preparo de diversos pratos ou mesmo chás, situação em que podem ser utilizado folhas secas e trituradas. Assim, o principal interesse do cultivo desta espécie é a obtenção de um maior volume de folhas.

O item 4.1. mostrou que antes da definição da composição da solução nutritiva, o sistema e a freqüência de fornecimento é mais importante. A irrigação intermitente foi responsável por uma produção três vezes maior do que quando as raizes ficaram submersas por períodos longos. Nos cultivos da planta, deve-se procurar manter as raízes submersas por períodos curtos, na ordem de $10 \mathrm{~min}$., intercalados por períodos sem irrigação de 2 a 3 horas, dependendo do desenvolvimento da planta. À medida que a planta cresce os intervalos entre as irrigações devem ser menores.

A maior concentração de $\mathrm{N}$ foi responsável pela maior produção de folhas, não apresentando outros efeitos negativos, podendo-se recomendar o aumento de $\mathrm{N}$ até o nivel de $420 \mathrm{mg} \mathrm{L}^{-1}$ de solução. Os resultados discutidos no item 4.2.3.1 indicam que concentrações muito acima de $420 \mathrm{mg} \mathrm{L}^{-1}$ de $\mathrm{N}$ não serão de interesse, pois não serão capazes de diminuir a relação entre raízes e parte aérea. Deve-se, também, evitar relações de $\mathrm{N}$ nítrico e $\mathrm{N}$ amoniacal superiores às utilizadas neste trabalho $(12,5 \%)$, para não comprometer o pH da solução e a absorção dos demais nutrientes.

Conforme discutido nos itens 4.2.3.1 e 4.2.3.2, a elevação da concentração do N na solução levará a um maior teor do nutriente nos tecidos da planta. Um acréscimo na concentração de $\mathrm{P}$ na solução, entre 31 e $62 \mathrm{mg} \mathrm{L}^{-1}$, deverá ser feito, a fim de se alcançar uma relação N:P mais apropriada. 


\subsection{Mentha arvensis $\mathrm{L}$.}

\subsubsection{Solução nutritiva}

\subsubsection{1 pH}

Os resultados das determinações do $\mathrm{pH}$ das soluções nos tambores, em seis momentos ao longo dos 67 dias de duração do experimento com M. arvensis, são apresentados na tabela 16 .

O motivo dos valores baixos de pH dos tratamentos Ca100, N420 e P62 são os mesmos dos discutidos para o experimento com M. crispa: o ion amônio, adicionado na forma de $\mathrm{NH}_{4} \mathrm{NO}_{3}$ nas soluções, liberou $\mathrm{H}^{+}$, e conseqüente abaixando o $\mathrm{pH}$.

Tabela 16. Valores de pH das soluções usadas no cultivo da M. arvensis L.

\begin{tabular}{|c|c|c|c|c|c|c|}
\hline \multirow[b]{2}{*}{ Tratamentos } & \multicolumn{6}{|c|}{ Dias após o plantio } \\
\hline & 0 & 16 & 36 & 58 & 67 & média \\
\hline Controle & 5,55 & 6,82 & 7,67 & 5,88 & 6,12 & $6,41 a^{1}$ \\
\hline N105 & 5,74 & 6,95 & 7,30 & 4,28 & 4,16 & $5,69 \mathrm{ab}$ \\
\hline N420 & 5,45 & 4,44 & 4,39 & 5,44 & 5,86 & $5,13 \mathrm{~b}$ \\
\hline $\mathrm{P} 1.5,5$ & 5,87 & 6,70 & 7,62 & 6,12 & 6,17 & $6,50 \mathrm{a}$ \\
\hline P62 & 5,28 & 4,84 & 6,85 & 4,77 & 4,84 & $5,32 b$ \\
\hline K 117 & 5,41 & 5,15 & 7,38 & 5,06 & 5,98 & $5,80 \mathrm{ab}$ \\
\hline K468 & 5,72 & 6,98 & 7,62 & 5,75 & 5,35 & $6,28 \mathrm{ab}$ \\
\hline $\mathrm{Ca} 100$ & 5,45 & 4,42 & 6,91 & 4,22 & 4,48 & $5,10 \mathrm{~b}$ \\
\hline $\mathrm{Ca} 400$ & 5,67 & 6,61 & 7,52 & 6,11 & 6,11 & $6,40 \mathrm{a}$ \\
\hline $\operatorname{Mg} 24$ & 5,70 & 5,00 & 7,20 & 6,00 & 5,88 & $5,96 a b$ \\
\hline $\operatorname{Mg} 96$ & 5,62 & 7,09 & 7,79 & 5,15 & 5,60 & $6,25 \mathrm{ab}$ \\
\hline
\end{tabular}

Números seguidos pelas mesmas letras, na coluna de médias, não diferem significativamente pelo teste de Tukey a $10 \%$ de probabilidade. 


\subsubsection{Condutividade elétrica}

A importância da condutividade elétrica, discutida no item 4.2.1.2., no decorrer do experimento é apresentada na tabela 17, onde observa-se uma diminuição importante dos valores entre o $15^{\circ}$ e $35^{\circ}$ dias após o plantio.

$\mathrm{Na}$ média das 4 observações de condutividade das soluções, somente o N, K, Ca na solução, mostraram efeitos significativamente diferentes do controle. A eq. (8) representa o efeito do número de dias, iteração $\mathrm{NCa}$ e $\mathrm{KMg}$, na condutividade elétrica da solução.

$$
\begin{aligned}
\mathrm{Y} & =1,301-3,134 \times 10^{-2} \times \mathrm{D}+1,335 \times 10^{-5} \times \mathrm{NCa}+2,268 \times 10^{-5} \times \mathrm{KMg} \\
\mathrm{R}^{2} & =0,820
\end{aligned}
$$

Onde:

$\mathrm{Y}=$ Condutividade elétrica em $\mathrm{mS} \mathrm{cm}^{-1}$;

$\mathrm{D}=$ Número de dias após o plantio;

$\mathrm{N}=$ Concentração de $\mathrm{N}$ na solução em $\mathrm{mg} \mathrm{L}^{-1}$;

$\mathrm{Ca}=$ Concentração de Ca na solução em $\mathrm{mg} \mathrm{L}^{-1}$,

$\mathrm{K}=$ Concentração de $\mathrm{K}$ na solução em $\mathrm{mg} \mathrm{L}^{-1}$;

$\mathrm{Mg}=$ Concentração de $\mathrm{Mg}$ na solução em $\mathrm{mg} \mathrm{L}^{-1}$.

Observou-se que o número de dias após o plantio do plantio, da mesma forma que para a $M$. crispa, é o principal responsável pela diminuição na condutividade elétrica da solução. $\mathrm{O}$ cálculo dos $\mathrm{R}^{2}$ parciais das variáveis dias do plantio (D), interação $\mathrm{NCa}$ e $\mathrm{KMg}$, foram 0,724; 0,080 e 0,017 respectivamente.

A comparação da eq. (8) com a eq. (1) da M. crispa, mostra que a M. arvensis L. absorve nutrientes mais rapidamente, pois o parâmetro multiplicador da variável dias 
após o plantio (D) é menor e portanto reduz mais rapidamente a condutividade elétrica da solução.

Tabela 17. Evolução da condutividade elétrica $\left(\mathrm{mS} \mathrm{cm}^{-1}\right)$ das soluções dos tratamentos da $M$. arvensis $L$.

\begin{tabular}{lllll}
\hline \multirow{2}{*}{ Tratamentos } & \multicolumn{4}{c}{ Dias após o plantio } \\
\cline { 2 - 5 } Controle & 1 & 15 & 35 & 67 \\
\cline { 2 - 5 } N105 & 1,70 & 1,80 & 0,45 & 0,10 \\
\hline N420 & 1,80 & 1,90 & 0,93 & 0,32 \\
\hline P15,5 & 2,40 & 3,20 & 1,55 & 0,06 \\
P62 & 1,80 & 2,00 & 0,60 & 0,04 \\
\hline K117 & 2,00 & 2,10 & 0,43 & 0,04 \\
K468 & 1,60 & 1,70 & 0,25 & 0,02 \\
\hline Ca100 & 2,40 & 2,60 & 0,82 & 0,09 \\
Ca400 & 1,60 & 1,70 & 0,34 & 0,04 \\
\hline Mg24 & 2,70 & 2,80 & 0,82 & 0,6 \\
Mg96 & 1,80 & 1,90 & 0,62 & 0,12 \\
\hline
\end{tabular}

\subsubsection{Produção}

\subsubsection{Massa de material seco}

As variações dos nutrientes estudados nas concentrações nas soluções nutritivas, apresentaram efeitos significativos sobre a produção de material seco das raízes e da parte aérea, como observa-se na tabela 18. 
A produção de raizes foi menor que o controle em todos os tratamentos com concentrações menores. Já os tratamentos que continham o dobro de nutriente do tratamento controle, não apresentaram produções de raízes superiores ao padrão, com exceção do tratamento Ca400. Esses resultados indicam que aumentos na concentração de $\mathrm{Ca}$ na solução poderão proporcionar melhores condições de desenvolvimento de raízes, que possibilita um maior potencial de desenvolvimento da planta toda.

Tabela 18. Produção de massa de material seco das raízes e da parte aérea de $M$. arvensis L., em função dos teores de nutrientes na solução nutritiva.

\begin{tabular}{lccc}
\hline \multirow{2}{*}{ Tratamentos } & \multicolumn{3}{c}{ Massa de material seco $(\mathrm{g})$} \\
\cline { 2 - 4 } Controle & Raízes & Parte aérea & Total \\
\cline { 2 - 4 } N105 & $27,66 \mathrm{a}$ & $61,78 \mathrm{a}$ & $89,44 \mathrm{a}$ \\
\hline N420 & $21,77 \mathrm{~b}$ & $40,45 \mathrm{~b}$ & $62,22 \mathrm{~b}$ \\
\hline P15,5 & $19,55 \mathrm{~b}$ & $80,84 \mathrm{c}$ & $100,39 \mathrm{c}$ \\
P62 & $20,35 \mathrm{~b}$ & $46,35 \mathrm{~b}$ & $66,70 \mathrm{~b}$ \\
\hline K117 & $21,12 \mathrm{~b}$ & $63,75 \mathrm{a}$ & $84,87 \mathrm{a}$ \\
\hline K468 & $20,61 \mathrm{~b}$ & $41,57 \mathrm{~b}$ & $62,68 \mathrm{~b}$ \\
\hline Ca100 & $23,80 \mathrm{~b}$ & $68,18 \mathrm{a}$ & $91,98 \mathrm{a}$ \\
Ca400 & $19,46 \mathrm{~b}$ & $53,22 \mathrm{~b}$ & $72,68 \mathrm{~b}$ \\
\hline Mg24 & $27,69 \mathrm{a}$ & $65,90 \mathrm{a}$ & $93,59 \mathrm{a}$ \\
\hline Mg96 & $17,60 \mathrm{~b}$ & $42,27 \mathrm{~b}$ & $59,87 \mathrm{~b}$ \\
\hline
\end{tabular}

Números seguidos pelas mesmas letras, nas colunas, não diferem significativamente. Comparações entre o controle e os tratamentos do mesmo nutriente.

As doses de $\mathrm{N}$ apresentaram aumentos de produção da parte aérea, indicando a possibilidade de se obter maiores produções com soluções mais concentradas no nutriente. Segundo Agren (1985), a proporção entre raizes e parte aérea pode indicar a condição nutricional da planta e do meio em que ela se desenvolve. Levin et al. (1989), 
com base nas premissas daquele trabalho, desenvolveram um modelo que mostra que as relações de massa de raízes e de folhas tendem a diminuir à medida que o meio torna-se mais rico em $\mathrm{N}$, até que essas relações tenham um comportamento assintótico.

As relações entre a massa das raízes e da parte aérea dos tratamentos N105, controle ( $\mathrm{N} 210)$ e $\mathrm{N} 420$, foram $0,54,0,45$ e 0,24 respectivamente, não mostrando $\mathrm{o}$ comportamento assintótico, que ocorre quando o meio contém a quantidade de nutrientes suficiente para a planta, conforme foi observado com a $M$. crisp (item 4.2.3.1).

A queda na relação de massa de raizes e parte aérea à medida que aumentou-se a concentração de $\mathrm{N}$ na solução, indica que soluções mais concentradas no elemento, além dos $420 \mathrm{mg} \mathrm{L}^{-1}$, poderão aumentar ainda mais a produção de folhas.

Os tratamentos com soluções menos concentradas em $\mathrm{P}, \mathrm{K}$ e Ca apresentaram produções significativamente inferiores às do controle. Já as doses mais elevadas proporcionaram produções semelhantes ao padrão, mostrando que os aumentos desses nutrientes não serão suficientes para se obter maiores produções da parte aérea.

O tratamento com maior concentração de $\mathrm{Mg}$ na solução $(\mathrm{Mg} 96)$ teve uma produção menor do que a do controle, mostrando efeito depressivo na produção dessa concentração.

Em todos os tratamentos a produção de massa de material seco da parte aérea foi cerca de duas vezes a produção de raízes em todos os tratamentos. Por este motivo, os resultados da produção total de material seco, que foi a soma das duas variáveis, são semelhantes às de parte aérea.

O estudo das regressões mostrou que a produção de material seco da parte aérea foi função da interação NK, PCa e o efeito quadrático da concentração de $K\left(K^{2}\right)$ na solução nutritiva, cujos $R^{2}$ parciais foram de 0,$543 ; 0,135$ e 0,039 respectivamente, conforme mostra a eq. (9).

$$
\begin{aligned}
\mathrm{Y} & =19,141+5,578 \times 10^{-4} \times \mathrm{NK}+1,722 \times 10^{-3} \times \mathrm{PCa}-7,410 \times 10^{-5} \times \mathrm{K}^{2} \\
\mathrm{R}^{2} & =0,718
\end{aligned}
$$


Onde:

$\mathrm{Y}=$ produção de massa da parte aérea em g/vaso;

$\mathrm{N}=$ Concentração de $\mathrm{N}$ na solução em $\mathrm{mg} \mathrm{L}^{-1}$;

$\mathrm{K}=$ Concentração de $\mathrm{K}$ na solução em $\mathrm{mg} \mathrm{L}^{-1}$;

$\mathrm{P}=$ Concentração de $\mathrm{P}$ na solução em $\mathrm{mg} \mathrm{L}^{-1}$;

$\mathrm{Ca}=$ Concentração de $\mathrm{Ca}$ na solução em $\mathrm{mg} \mathrm{L}^{-1}$.

\subsubsection{Número de pares de folhas}

Na tabela 19 estão os resultados das contagens de pares de folhas por vaso ao longo do experimento. Somente o $\mathrm{N}$ e o P, além dos dias após o plantio (D), apresentaram efeito significativo sobre o número de pares de folhas final. As diferenças observadas nos demais tratamentos nas primeiras amostragens não se sustentaram, indicando que deviam-se a diferenças das próprias plantas.

Nessa espécie não se observou um número menor de pares de folhas no tratamento mais rico em $\mathrm{Ca}(\mathrm{Ca} 400)$, como ocorreu com a $M$. crispa, indicando uma maior tolerância ao $\mathrm{Cl}$, conforme discutido no item 4.2.2.2.

O estudo das regressões mostrou que o número de pares de folhas é função dos dias após o plantio (D), do quadrado da concentração de $\mathrm{N}$ na solução $\left(\mathrm{N}^{2}\right)$ e da interação CaMg na solução, que apresentaram $R^{2}$ parciais de 0,886, 0,12 e 0,003 respectivamente, conforme mostra a eq. (10).

$$
\begin{aligned}
& \mathrm{Y}=-63,585+4,836 \times \mathrm{D}+3,340 \times 10^{-4} \times \mathrm{N}^{2}+1,313 \times 10^{-3} \times \mathrm{CaMg} \\
& \mathrm{R}^{2}=0,901
\end{aligned}
$$

Onde:

$\mathrm{Y}=$ Número de pares de folhas/vaso; 
$\mathrm{D}=$ Número de dias após o plantio;

$\mathrm{N}=$ Concentração de $\mathrm{N}$ na solução em $\mathrm{mg} \mathrm{L}^{-1}$;

$\mathrm{Ca}=$ Concentração de Ca na solução em $\mathrm{mg} \mathrm{L}^{-1}$;

$\mathrm{Mg}=$ Concentração de $\mathrm{Mg}$ na solução em $\mathrm{mg} \mathrm{L}^{-1}$.

Tabela 19. Número médio de pares de folhas de M. arvensis L. por vaso, em função dos teores de nutrientes na solução nutritiva.

\begin{tabular}{|c|c|c|c|c|}
\hline \multirow{3}{*}{ Tratamentos } & \multicolumn{4}{|c|}{ Dias após o plantio } \\
\hline & 9 & 16 & 30 & 69 \\
\hline & \multicolumn{4}{|c|}{ (número de pares de folhas/planta) } \\
\hline Controle & $20,00 a^{1}$ & $53,50 \mathrm{a}$ & $111,50 \mathrm{a}$ & $333,00 \mathrm{a}$ \\
\hline N105 & $24,50 \mathrm{a}$ & $50,50 \mathrm{a}$ & $77,25 b$ & $253,25 b$ \\
\hline $\mathrm{N} 420$ & $25,50 \mathrm{~b}$ & $51,00 \mathrm{a}$ & $100,25 \mathrm{c}$ & $453,50 \mathrm{c}$ \\
\hline $\mathrm{P} 15,5$ & $24,25 a$ & $47,00 \mathrm{a}$ & $65,50 \mathrm{~b}$ & $256,00 \mathrm{~b}$ \\
\hline P62 & $20,25 \mathrm{a}$ & $52,75 \mathrm{a}$ & $93,00 \mathrm{c}$ & $289,25 \mathrm{ab}$ \\
\hline K117 & $18,75 \mathrm{ab}$ & $43,75 \mathrm{ab}$ & $73,50 \mathrm{~b}$ & $309,25 \mathrm{a}$ \\
\hline K468 & $15,25 b$ & $40,25 b$ & $98,25 \mathrm{c}$ & $276,25 \mathrm{a}$ \\
\hline Cal00 & $18,00 \mathrm{a}$ & $51,75 a$ & $74,25 b$ & $307,50 \mathrm{a}$ \\
\hline $\mathrm{Ca} 400$ & $21,50 \mathrm{a}$ & $69,00 \mathrm{~b}$ & $103,25 \mathrm{a}$ & $333,25 \mathrm{a}$ \\
\hline Mg24 & $18,00 \mathrm{a}$ & $43,50 \mathrm{a}$ & $78,00 \mathrm{~b}$ & $294,00 \mathrm{a}$ \\
\hline $\operatorname{Mg} 96$ & $24,00 \mathrm{~b}$ & $54,75 \mathrm{ab}$ & $127,75 \mathrm{c}$ & $290,00 \mathrm{a}$ \\
\hline
\end{tabular}

Números seguidos pelas mesmas letras, nas colunas, não diferem significativamente. Comparações entre o controle e os tratamentos do mesmo nutriente.

\subsubsection{Teores de nutrientes na parte aérea}

Todos os tratamentos estudados apresentaram uma relação direta entre a concentração do nutriente na solução e seu teor na parte aérea da planta. A tabela 20 
apresenta os resultados obtidos, onde observa-se que todos os tratamentos com soluções menos concentradas dos nutrientes, apresentaram teores significativamente inferiores ao controle, com exceção tratamento P15,5. Nas plantas tratadas com a solução mais rica, os teores foram todos significativamente superiores ao padrão, sem nenhuma exceção. Essa relação direta entre a concentração do nutriente do meio e o teor da parte aérea, aqui observada, também é descrita por diversos autores (Marschener, 1991; Mengel, 1981; Raij, 1981; Malavolta, 1980;) e repetida no experimento com M. crispa (item 4.2.3.).

Tabela 20. Teores de macronutrienes na massa de material seco da parte aérea de $M$. arvensis L., em função dos teores de nutrientes na solução nutritiva.

\begin{tabular}{|c|c|c|c|c|c|c|}
\hline \multirow[b]{2}{*}{ Tratamentos } & \multicolumn{6}{|c|}{ Teores de nutriente na parte aérea $\left(\mathrm{g} \mathrm{kg}^{-1}\right)$} \\
\hline & $\mathrm{N}$ & $P$ & $\mathrm{~K}$ & $\mathrm{Ca}$ & $\mathrm{Mg}$ & $\mathrm{S}$ \\
\hline Controle & $10,88 \mathrm{a}^{1}$ & $1,26 \mathrm{a}$ & $9,89 a$ & $9,05 \mathrm{a}$ & $2,27 a$ & $3,01 \mathrm{a}$ \\
\hline N105 & $7,63 b$ & $1,54 \mathrm{a}$ & $13,52 b$ & $9,48 \mathrm{a}$ & $1,77 \mathrm{~b}$ & $3,55 \mathrm{a}$ \\
\hline N420 & $22,90 \mathrm{c}$ & $2,81 b$ & $13,46 b$ & $11,95 b$ & $3,55 \mathrm{c}$ & $2,90 \mathrm{a}$ \\
\hline $\mathrm{P} 15,5$ & $10,78 \mathrm{a}$ & $0,97 a$ & $9,18 \mathrm{a}$ & $9,06 \mathrm{a}$ & $1,89 b$ & $2,76 a$ \\
\hline P62 & $11,53 \mathrm{a}$ & $2,20 b$ & $8,57 \mathrm{a}$ & $8,43 \mathrm{a}$ & $1,73 b$ & $3,13 a$ \\
\hline K117 & $7,55 b$ & $1,32 \mathrm{a}$ & $4,85 b$ & $9,42 \mathrm{a}$ & $1,83 b$ & $2,37 a$ \\
\hline $\mathrm{K} 468$ & $10,73 a$ & $1,79 b$ & $20,78 c$ & $9,16 \mathrm{a}$ & $1,81 b$ & $3,46 b$ \\
\hline $\mathrm{Ca} 100$ & $9,95 a$ & $1,39 a$ & $9,82 \mathrm{a}$ & $5,66 b$ & $1,93 b$ & $2,94 a$ \\
\hline $\mathrm{Ca} 400$ & $12,00 \mathrm{a}$ & $1,15 \mathrm{a}$ & $11,36 \mathrm{a}$ & $12,48 \mathrm{c}$ & $2,07 \mathrm{ab}$ & $2,48 a$ \\
\hline $\mathrm{Mg} 24$ & $10,33 a$ & $1,76 b$ & $12,36 a$ & $10,51 \mathrm{ab}$ & $1,51 \mathrm{~b}$ & $3,49 a$ \\
\hline Mg96 & $9,75 \mathrm{a}$ & $1,65 \mathrm{a}$ & $10,71 \mathrm{a}$ & $10,97 b$ & $3,87 \mathrm{c}$ & $4,31 b$ \\
\hline
\end{tabular}

Números seguidos pelas mesmas letras, nas colunas, não diferem significativamente. Comparações entre o controle e os tratamentos do mesmo nutriente.

Todos os tratamentos receberam soluções com a mesma concentração de micronutrientes, porém na tabela 21 observa-se diferenças significativas nos teores 
desses nutrientes na parte aérea das plantas, mostrando uma relação evidente com as concentrações de macronutrientes no meio.

Tabela 21. Teores de micronutrientes na massa de material seco da parte aérea de $M$. arvensis L., em função dos teores de nutrientes na solução nutritiva.

\begin{tabular}{|c|c|c|c|c|c|}
\hline \multirow[b]{2}{*}{ Tratamentos } & \multicolumn{5}{|c|}{ Teores de nutriente nas parte aérea $\left(\mathrm{mg} \mathrm{kg}^{-1}\right)$} \\
\hline & $\mathrm{Fe}$ & $\mathrm{Zn}$ & $\mathrm{Mn}$ & $\mathrm{B}$ & $\mathrm{Cu}$ \\
\hline Controle & $158,50 \mathrm{a}^{1}$ & $38,85 \mathrm{a}$ & $21,00 \mathrm{a}$ & $22,00 \mathrm{a}$ & $20,58 \mathrm{a}$ \\
\hline N105 & $197,75 \mathrm{a}$ & $38,28 \mathrm{a}$ & $56,13 b$ & $21,56 \mathrm{a}$ & $13,50 \mathrm{a}$ \\
\hline N420 & $288,25 b$ & $71,65 b$ & $40,93 c$ & $25,83 b$ & $19,53 \mathrm{a}$ \\
\hline $\mathrm{P} 15,5$ & $201,75 b$ & $50,90 b$ & $18,60 \mathrm{a}$ & $23,13 \mathrm{a}$ & $24,40 \mathrm{a}$ \\
\hline P62 & $184,25 \mathrm{ab}$ & $40,13 a$ & $19,75 \mathrm{a}$ & $16,45 b$ & $11,00 \mathrm{~b}$ \\
\hline $\mathrm{K} 117$ & $134,25 \mathrm{a}$ & $37,80 \mathrm{a}$ & $47,55 b$ & $16,45 b$ & $14,93 \mathrm{a}$ \\
\hline K468 & $177,00 \mathrm{ba}$ & $46,05 a$ & $12,55 c$ & $13,47 b$ & $14,85 \mathrm{a}$ \\
\hline Cal00 & $194,50 \mathrm{a}$ & $43,93 a$ & $19,60 \mathrm{a}$ & $18,07 \mathrm{~b}$ & $35,15 b$ \\
\hline $\mathrm{Ca} 400$ & $220,00 \mathrm{ba}$ & $46,45 \mathrm{a}$ & $24,25 \mathrm{a}$ & $27,89 c$ & $17,43 \mathrm{a}$ \\
\hline Mg24 & $207,25 b$ & $41,58 a$ & $51,28 b$ & $20,13 a$ & $12,53 \mathrm{a}$ \\
\hline Mg96 & $225,75 b$ & $44,45 a$ & $39,93 c$ & $26,95 b$ & $15,25 \mathrm{a}$ \\
\hline
\end{tabular}

Números seguidos pelas mesmas letras, nas colunas, não diferem significativamente. Comparações entre o controle e os tratamentos do mesmo nutriente.

\subsubsection{Efeito das doses de $\mathrm{N}$ nos teores de nutrientes parte aérea}

O teor de $\mathrm{N}$ nas folhas mostrou-se proporcional ao aumento da concentração do nutriente na solução, conforme afirmam Epstein (1975) e Malavolta (1980). A comparação desses resultados com os obtidos com a $M$. crispa submetida aos mesmos tratamentos, discutidos no item 4.2.3.1., indicam que a queda no teor dos nutrientes nas folhas da $M$. arvensis L., quando cultivada em solução nutritiva com menores 
concentrações de $\mathrm{N}$, é muito maior, mostrando novamente uma exigência maior de nutrientes na solução, ou um solo mais fértil, conforme indicou Maia (1994).

Os teores de $\mathrm{P}, \mathrm{Ca}$ e $\mathrm{Mg}$ na parte aérea foram maiores nos tratamentos com maiores concentrações em $\mathrm{N}$, inclusive no tratamento $\mathrm{N} 420$, que recebeu $7,5 \mathrm{mM} \mathrm{L}^{-1}$ de $\mathrm{NH}_{4} \mathrm{NO}_{3}$, contendo $\mathrm{N}$ amoniacal, que competiria para a menor absorção de cátions. Esses resultados confirmam os resultados de Jones et al. (1991), discutidos no item 4.2.3.1., segundo o qual, a absorção e o acúmulo nas folhas dos outros nutrientes seriam mais afetados pelo $\mathrm{pH}$ da solução do que pela forma do $\mathrm{N}$ presente no meio, quando a relação de $\mathrm{N}$ nítrico e $\mathrm{N}$ amoniacal for, como foi neste trabalho, de até 3:1

$\mathrm{O}$ teor maior de $\mathrm{Zn}$ na massa do material seco da parte aérea das plantas tratadas com solução com maior concentração de $\mathrm{N}$, observado também na $M$. crispa, já era previsto por Jones et al.(1991), tanto pelo simples aumento de $\mathrm{N}$ no meio, como pela presença acidificante do $\mathrm{N}$ amoniacal.

Segundo Dugger (1983), o teor maior de B nos tecidos da parte aérea, observado quando tratou-se as plantas com a solução mais rica em N (tratamento N420) deveu-se a uma maior massa de folhas do tratamento que promoveram uma maior absorção de água. $\mathrm{O}$ autor sugere que, quanto maior o volume de água transpirada pela planta, o qual é tanto maior quanto maior for a área foliar, maior será a quantidade de solução absorvida e, conseqüentemente, o $\mathrm{B}$ absorvido e presente tanto na parte aérea (Tabela 21), quanto nas raízes (Tabela 23).

$\mathrm{O}$ estudo das regressões mostraram que o teor de $\mathrm{N}$ na parte aérea foi função principalmente, do quadrado da concentração do nutriente na solução e da interação $\mathrm{KCa}$, que apresentaram $\mathrm{R}^{2}$ parciais de 0,792 e 0,027 respectivamente. Esses valores mostram que o teor de $\mathrm{N}$ na parte aérea da $M$. arvensis é muito mais afetado pela concentração do nutriente no meio, do que na $M$. crispa, como pode-se perceber comparando-se as equações (4) do item 4.2.3.1. e (11).

$$
\begin{aligned}
\mathrm{Y} & =0,465+9,45 \times 10^{-6} \times \mathrm{N}^{2}+3,14 \times 10^{-6} \times \mathrm{KCa} \\
\mathrm{R}^{2} & =0,819
\end{aligned}
$$


Onde:

$\mathrm{Y}=$ Teor de $\mathrm{N}$ na parte aérea em $\mathrm{g} \mathrm{kg}^{-1}$;

$\mathrm{N}=$ Concentração de $\mathrm{N}$ na solução em $\mathrm{mg} \mathrm{L}^{-1}$;

$\mathrm{K}=$ Concentração de $\mathrm{K}$ na solução em $\mathrm{mg} \mathrm{L}^{-1}$;

$\mathrm{Ca}=$ Concentração de Ca na solução em $\mathrm{mg} \mathrm{L}^{-1}$.

\subsubsection{Efeito das doses de $P$ nos teores de nutrientes na parte aérea}

$\mathrm{O}$ aumento na concentração de $\mathrm{P}$ da solução aumentou o teor do próprio nutriente nos tecido da parte aérea das plantas, não afetando nenhum dos outros macronutrientes analisados, como mostra a tabela 20. Já os micronutrientes Fe, Zn, B e $\mathrm{Cu}$, tiveram seus teores reduzidos significativamente. Vários autores demonstram essa relação inversa entre a disponibilidade de P no meio e o teor desses micronutrientes nas folhas (Marschner, 1995; Jones et al., 1991; Dugger, 1983).

\subsubsection{Efeito das doses de $\mathrm{K}$ nos teores de nutrientes na parte aérea}

A parte aérea das plantas do tratamento com concentração mais elevada de $\mathrm{K}$ (K468), apresentou teores de $\mathrm{K}$ e $\mathrm{P}$, significativamente mais altos do que o controle (K234). Já o tratamento menos concentrado (K117) reduziu os teores de N, e S.

A diminuição do teor de $\mathrm{N}$ nos tecidos da parte aérea da planta, em função da diminuição da concentração de K na solução, foi prevista por vários autores (Marschner, 1995; Jones et al. 1991; Malavolta, 1980), demonstrando a forte interrelação entre esses dois elementos. O S apresentou um comportamento semelhante ao $\mathrm{N}$, conforme observaram Sinha \& Singh (1984) e Maia (1994). 
$\mathrm{O}$ aumento do teor de $\mathrm{K}$, diretamente proporcional à concentração do elemento na solução, foi determinado pelo método "stepwise", conforme mostra a eq. (12).

$\mathrm{Y}=0,497+4,423 \times 10^{-2} \times \mathrm{K}$

$\mathrm{R}^{2}=0,619$

Onde:

$\mathrm{Y}=$ Teor de $\mathrm{K}$ na parte aérea das plantas em $\mathrm{g} \mathrm{kg}^{-1}$;

$\mathrm{K}=$ Concentração de $\mathrm{K}$ na solução em $\mathrm{mg} \mathrm{L}^{-1}$.

Utilizando-se o método de regressão de incrementos de $\mathrm{R}^{2}$, chegou-se a uma fórmula mais apropriada, que contempla a interrelação $\mathrm{N} \mathrm{K}$, conforme mostra a eq. (13).

$\mathrm{Y}=-6,842+1,149 \times 10^{-1} \times \mathrm{K}+1,474 \times 10^{-4} \times \mathrm{N}^{2}-3,324 \times 10^{-4} \times \mathrm{NK}$

$\mathrm{R}^{2}=0,691$

Onde:

$\mathrm{Y}=$ Teor de $\mathrm{K}$ na parte aérea das plantas em $\mathrm{g} \mathrm{kg}^{-1}$;

$\mathrm{K}=$ Concentração de $\mathrm{K}$ na solução em $\mathrm{mg} \mathrm{L}^{-1}$;

$\mathrm{N}=$ Concentração de $\mathrm{N}$ na solução em $\mathrm{mg} \mathrm{L}^{-1}$.

O teor de Mn na parte aérea diminuiu significativamente, quando tratou-se as plantas com soluções mais concentradas em K (Tabela 21). Esse efeito foi descrito por Jones et al.(1991), ocorrendo em folhas de citros e tomate, porém o estudo da regressão do teor de Mn nas folhas, pelo método "stepwise" mostrou que a concentração de K na solução explica somente uma pequena parcela do teor de $\mathrm{Mn}$ na folha, conforme mostra o $R^{2}$ da a eq. (14).

$\mathrm{Y}=55,133-9,473 \times 10^{-2} \times \mathrm{K}$ 
$\mathrm{R}^{2}=0,219$

Onde:

$\mathrm{Y}=$ Teor de $\mathrm{Mn}$ na parte aérea em $\mathrm{mg} \mathrm{kg}^{-1}$;

$\mathrm{K}=$ Concentração de $\mathrm{K}$ na solução em $\mathrm{mg} \mathrm{L}^{-1}$.

A regressão desenvolvida pelo método de incremento máximo de $\mathrm{R}^{2}$, mostrou que o teor de Mn nas folhas foi função da concentração dos nutrientes estudados, conforme mostra a eq. (15).

$$
\begin{aligned}
& \mathrm{Y}=24,602+3,328 \times \mathrm{P}+1,328 \times 10^{-3} \times \mathrm{N} 2+5,806 \times 10^{-4} \times \mathrm{K}^{2}+3,419 \times 10^{-5} \times \mathrm{Ca}^{2}+ \\
& \quad 2,544 \times 10^{-2} \times \mathrm{Mg}^{2}-1,541 \times 10^{-2} \times \mathrm{NMg}-1,417 \times 10^{-2} \times \mathrm{PK} \\
& \mathrm{R}^{2}=0,857
\end{aligned}
$$

Onde:

$\mathrm{Y}=$ Teor de $\mathrm{Mn}$ na parte aérea em $\mathrm{mg} \mathrm{kg}^{-1}$;

$\mathrm{N}=$ Concentração de $\mathrm{N}$ na solução em $\mathrm{mg} \mathrm{L}^{-1}$;

$\mathrm{P}=$ Concentração de $\mathrm{P}$ na solução em $\mathrm{mg} \mathrm{L}^{-1}$;

$\mathrm{K}=$ Concentração de $\mathrm{K}$ na solução em $\mathrm{mg} \mathrm{L}^{-1}$;

$\mathrm{Ca}=$ Concentração de Ca na solução em $\mathrm{mg} \mathrm{L}^{-1}$;

$\mathrm{Mg}=$ Concentração de $\mathrm{Mg}$ na solução em $\mathrm{mg} \mathrm{L}^{-1}$.

O efeito antagônico entre o Fe e Mn, que se acumulam na forma de precipitados nas placas de mucilagem acumuladas nas raízes, conforme descreveu Reisenauer (1994), pode ser claramente observado nos resultados apresentados na tabela $21 . \AA$ medida que aumentou o teor de Fe na parte aérea e raízes, o teor de Mn diminuiu significativamente. Efeito semelhante pode ser observado na $M$. crispa (Tabela 11). 


\subsubsection{Efeito das doses de Ca nos teores de nutrientes na parte aérea}

As concentrações maiores de Ca na solução nutritiva, alterou significativamente o teor do próprio macronutriente na parte aérea da M. arvensis L., além dos micronutrientes $\mathrm{Cu}$ e B, conforme mostram as tabelas 20 e 21 .

Jones et al (1991), mostram os mesmos resultados, ou seja, aumento no teor de B nas folhas de tomateiro, quando cultivado em solução nutritiva mais rica em Ca e, um menor teor de $\mathrm{Cu}$ em pastagens cultivadas em solos mais ricos em $\mathrm{Ca}$ devido às calagens,

\subsubsection{Efeito das doses de Mg nos teores de nutrientes na parte aérea}

O aumento na concentração de $\mathrm{Mg}$ na solução nutritiva, levou a um aumento nos teores de $\mathrm{Mg}$, S e B na parte aérea, como a correlação positiva, apresentada por Joes et al.(1991) e uma diminuição o teor de $P$, que não ocorreu em nenhum trabalho consultado.

O estudo das regressões mostrou que a concentração de $\mathrm{Mg}$ nas folhas é uma função, conforme mostra a eq. (16).

$$
\begin{aligned}
\mathrm{Y} & =0,9193+1,153 \times 10^{-5} \times \mathrm{N}^{2}-7,691 \times 10^{-5} \times \mathrm{P}^{2}+2,732 \times 10^{-4} \times \mathrm{Mg}^{2} \\
\mathrm{R}^{2} & =0,881
\end{aligned}
$$

Onde:

$\mathrm{Y}=$ Teor de $\mathrm{Mg}$ na parte aérea em $\mathrm{g} \mathrm{kg}^{-1}$;

$\mathrm{N}=$ Concentração de $\mathrm{N}$ na solução em $\mathrm{mg} \mathrm{L}^{-1}$; 
$\mathrm{P}=$ Concentração de $\mathrm{P}$ na solução em $\mathrm{mg} \mathrm{L}^{-1}$;

$\mathrm{Mg}=$ Concentração de $\mathrm{Mg}$ na solução em $\mathrm{mg} \mathrm{L}^{-1}$.

Os $R^{2}$ parciais das variáveis $\mathrm{N}^{2}, \mathrm{P}^{2}$ e $\mathrm{Mg}^{2}$, foram $0,020,0,008$ e 0,811 respectivamente.

\subsubsection{Teores de nutrientes nas raízes}

Os teores de $\mathrm{N}$ nas raízes de $M$. arvensis $\mathrm{L}$. foram aproximadamente os mesmos dos registrados no material da parte aérea, conforme observa-se na comparação das tabelas 20 e 22, porém, pode-se inferir que os teores dos nutrientes nas folhas serão mais elevados, uma vez que ele fez parte do material analisado, uma quantidade expressiva de ramos e hastes, cujos teores de $\mathrm{N}$ são menores (Maia, 1994). 
Tabela 22. Teores de macronutrienes na massa de material seco de raízes de $M$. arvensis L., em função dos teores de nutrientes na solução nutritiva.

\begin{tabular}{|c|c|c|c|c|c|c|}
\hline \multirow[b]{2}{*}{ Tratamentos } & \multicolumn{6}{|c|}{ Teores de nutriente nas raízes $\left(\mathrm{g} \mathrm{kg}^{-1}\right)$} \\
\hline & $\mathrm{N}$ & $\mathrm{P}$ & $\mathrm{K}$ & $\mathrm{Ca}$ & $\mathrm{Mg}$ & S \\
\hline Controle & $8,50 a^{1}$ & $1,64 \mathrm{a}$ & $10,97 a$ & $6,01 \mathrm{a}$ & $3,20 \mathrm{a}$ & $1,80 \mathrm{a}$ \\
\hline N105 & $6,73 b$ & $3,31 b$ & $16,98 b$ & $6,87 \mathrm{a}$ & $5,09 b$ & $2,34 b$ \\
\hline N420 & $21,30 \mathrm{c}$ & $2,99 \mathrm{c}$ & $11,86 \mathrm{a}$ & $7,02 \mathrm{a}$ & $3,07 \mathrm{a}$ & $4,03 c$ \\
\hline $\mathrm{P} 1 \overline{5,5}$ & $9,45 \mathrm{a}$ & $1,11 \mathrm{~b}$ & $11,35 \mathrm{a}$ & $5,86 a$ & $4,49 b$ & $1,69 a$ \\
\hline P62 & $10,93 b$ & $3,17 \mathrm{c}$ & $10,00 \mathrm{a}$ & $4,82 \mathrm{a}$ & $3,57 \mathrm{ab}$ & $2,76 b$ \\
\hline $\mathrm{K} 117$ & $9,18 \mathrm{a}$ & $1,73 \mathrm{ab}$ & $5,61 b$ & $5,30 a$ & $3,30 \mathrm{a}$ & $1,69 a$ \\
\hline K468 & $8,40 \mathrm{a}$ & $1,95 b$ & $19,64 c$ & $6,63 \mathrm{a}$ & $5,13 b$ & $4,32 b$ \\
\hline Cal00 & $11,08 \mathrm{~b}$ & $1,89 a$ & $8,16 b$ & $3,28 b$ & $2,52 \mathrm{a}$ & $3,10 b$ \\
\hline $\mathrm{Ca} 400$ & $8,48 \mathrm{a}$ & $1,50 \mathrm{~b}$ & $8,55 b$ & $13,14 c$ & $5,17 b$ & $1,99 a$ \\
\hline $\mathrm{Mg} 24$ & $9,88 \mathrm{~b}$ & $2,24 b$ & $10,33 \mathrm{ba}$ & $5,76 a$ & $2,68 a$ & $1,36 b$ \\
\hline Mg96 & $8,80 \mathrm{ab}$ & $1,79 a$ & $9,05 b$ & $6,16 a$ & $6,72 b$ & $1,83 \mathrm{ab}$ \\
\hline
\end{tabular}

Números seguidos pelas mesmas letras, nas colunas, não diferem significativamente. Comparações entre o controle e os tratamentos do mesmo nutriente.

Os teores de $\mathrm{P}$ e de $\mathrm{Mg}$ foram maiores nas raízes do que nas folhas, na maioria dos tratamentos estudados, o inverso ao que ocorreu com o $\mathrm{Ca}$ e $\mathrm{S}$.

$\mathrm{O}$ teor de $\mathrm{P}$ nas raizes, foi função das variáveis $\mathrm{P}, \mathrm{N}, \mathrm{N}^{2}$ e da interação $\mathrm{CaMg}$, que tiveram $R^{2}$ parciais de $0,344,0,448,0,065$ e 0,026 respectivamente, conforme mostra a eq. (17).

$$
\begin{aligned}
\mathrm{Y}= & 5,022-3,333 \times 10^{-2} \times \mathrm{N}+4,374 \times 10^{-2} \times \mathrm{P}+6,155 \times 10^{-5} \times \mathrm{N} 2- \\
& 2,585 \times 10^{-5} \times \mathrm{CaMg} \\
\mathrm{R}^{2}= & 0,882
\end{aligned}
$$


Onde:

$\mathrm{Y}=$ Teor de $\mathrm{P}$ na raiz em $\mathrm{g} \mathrm{kg}^{-1}$;

$\mathrm{P}=$ Concentração de $\mathrm{P}$ na solução em $\mathrm{mg} \mathrm{L}^{-1}$;

$\mathrm{N}=$ Concentração de $\mathrm{N}$ na solução em $\mathrm{mg} \mathrm{L}^{-1}$;

$\mathrm{Ca}=$ Concentração de Ca na solução em $\mathrm{mg} \mathrm{L}^{-1}$;

$\mathrm{Mg}=$ Concentração de $\mathrm{Mg}$ na solução em $\mathrm{mg} \mathrm{L}^{-1}$.

Os teores de Ca nas raizes foram menores do que os observados na parte aérea, sendo que a concentração do nutriente foi função das variáveis: $\mathrm{Ca}, \mathrm{P}^{2}, \mathrm{PK}$ e $\mathrm{K}^{2}$, que apresentaram $R^{2}$ de $0,809,0,022,0,012$ e 0,013 respectivamente, conforme mostra a eq. (18).

$$
\begin{aligned}
& \mathrm{Y}=-1,102+3,318 \times 10^{2} \times \mathrm{Ca}-1,952 \times 10^{-3} \times \mathrm{P}^{2}-2,310 \times 10^{-5} \times \mathrm{K}^{2}+ \\
& 5,541 \times 10^{-4} \mathrm{PK} \\
& \mathrm{R}^{2}=0,857
\end{aligned}
$$

Onde:

$\mathrm{Y}=$ Teor de Ca na raiz em $\mathrm{g} \mathrm{kg}^{-1}$;

$\mathrm{P}=$ Concentração de $\mathrm{P}$ na solução em $\mathrm{mg} \mathrm{L}^{-1}$;

$\mathrm{Ca}=$ Concentração de Ca na solução em $\mathrm{mg} \mathrm{L}^{-1}$;

$\mathrm{K}=$ Concentração de $\mathrm{K}$ na solução em $\mathrm{mg} \mathrm{L}^{-1}$.

Assim, como ocorreu na parte aérea, a menor concentração de Mn nas raizes das plantas cultivadas com solução enriquecida com $\mathrm{N}$ amoniacal (Tabela 23), deve-se ao fato do micronutriente ser preferencialmente absorvido em presença de $\mathrm{N}$ nitrico, conforme foi observado por Jones et al. (1991). O mesmo autor cita, que a relação direta entre o aumento do $\mathrm{N}$ no meio e o teor de $\mathrm{Cu}$ nos tecidos, sem atingir-se um nível tóxico, conforme ocorreu neste trabalho, no tratamento N420, que indica um equilibrio entre o $\mathrm{N}$ e Fe disponivel para a planta. 
Tabela 23. Teores de micronutrientes na massa de material seco de raízes de M. arvensis L., em função dos teores de nutrientes na solução nutritiva.

\begin{tabular}{|c|c|c|c|c|c|}
\hline \multirow[b]{2}{*}{ Tratamentos } & \multicolumn{5}{|c|}{ Teores de nutriente nas raizes $\left(\mathrm{mg} \mathrm{kg}^{-1}\right)$} \\
\hline & $\mathrm{Fe}$ & $\mathrm{Zn}$ & $\mathrm{Mn}$ & $\mathrm{B}$ & $\mathrm{Cu}$ \\
\hline Controle & $927,00 a^{1}$ & $59,18 \mathrm{a}$ & $29,25 a$ & $16,84 a$ & $22,18 \mathrm{a}$ \\
\hline N105 & $1460,75 b$ & $144,73 b$ & $42,73 b$ & $18,81 \mathrm{a}$ & $13,33 b$ \\
\hline N420 & $1408,00 b$ & $95,50 \mathrm{c}$ & $17,85 \mathrm{c}$ & $27,60 \mathrm{~b}$ & $21,28 \mathrm{a}$ \\
\hline $\mathrm{P} 15,5$ & $824,75 a$ & $58,43 a$ & $36,65 b$ & $23,32 b$ & $19,05 \mathrm{a}$ \\
\hline P62 & $1534,25 b$ & $105,13 b$ & $30,55 \mathrm{ab}$ & $19,55 \mathrm{ab}$ & $12,95 b$ \\
\hline $\mathrm{K} 117$ & $1356,00 \mathrm{~b}$ & $98,90 b$ & $55,70 b$ & $18,02 \mathrm{a}$ & $20,35 \mathrm{a}$ \\
\hline $\mathrm{K} 468$ & $1234,50 b$ & $118,05 b$ & $44,58 c$ & $16,75 \mathrm{a}$ & $19,63 \mathrm{a}$ \\
\hline Cal00 & $1243,25 b$ & $52,85 a$ & $20,38 b$ & $21,12 b$ & $13,45 b$ \\
\hline $\mathrm{Ca} 400$ & $1080,50 \mathrm{ba}$ & $82,23 b$ & $32,78 \mathrm{a}$ & $15,96 a$ & $14,20 \mathrm{~b}$ \\
\hline $\mathrm{Mg} 24$ & $1151,25 \mathrm{ab}$ & $101,43 b$ & $34,93 \mathrm{ab}$ & $13,31 b$ & $10,95 b$ \\
\hline Mg96 & $1280,50 \mathrm{~b}$ & $88,63 b$ & $40,90 b$ & $18,50 \mathrm{a}$ & $9,88 b$ \\
\hline
\end{tabular}

Números seguidos pelas mesmas letras, nas colunas, não diferem significativamente. Comparações entre o controle e os tratamentos do mesmo nutriente.

A queda acentuada no teor de micronutrientes à medida que se aumentou a dose de $\mathrm{P}$ na solução nutritiva, observada no material seco da parte aérea, também foi observado nas raizes, com exceção do Fe e $\mathrm{Zn}$ que apresentaram teores mais elevados nas maiores doses.

O teor de Fe, sempre maior nas raízes do que na parte aérea, concentrou-se mais nos órgão subterrâneos, quanto maior a concentração de $\mathrm{P}$ na solução. A relação entre o teor de Fe nas raízes e parte aérea (Tabelas 21 e 23) nos tratamentos P15,5, P31 (controle) e P62, foram 4, 6 e 10 vezes, respectivamente. Esses valores são semelhantes aos discutidos dor Jones et al. (1991) que mostram relações semelhantes para o Fe e Zn, 
e que ocorre em concentrações menores, mas com o mesmo comportamento. Neste trabalho as relações foram 1,2, 1,5 e 2,6, para os mesmos tratamentos com P.

$\mathrm{O}$ maior teor de $\mathrm{Mn}$ e $\mathrm{Zn}$ nas raízes, no tratamento mais rico em $\mathrm{Ca}$, é semelhante ao que Jones et al. (1991) observaram em laranjeiras, que explica o comportamento diferente do esperado devido à adição de $\mathrm{CaCl}_{2}$, para o aumento da concentração.

\subsubsection{Estimativa do teor de clorofila através do valor SPAD}

Os valores SPAD obtidos pelo clorofilometro na M. urvensis L. (Tabela 24), apresentaram comportamento semelhante aos valores observados na M. crispa, já discutidos no item 4.2.5. Como pode se observar, comparando-se os valores 14,933 e 18,420, do "intercept" das eq. (7) e (19), das duas espécies, a M. arvensis L apresentou mais clorofila em suas folhas do que a M. crispa.

A leitura do valor SPAD, função definida pela eq. (19), foi influenciada pelo número de dias após o plantio e pelas baixas concentrações de $\mathrm{N}$ e $\mathrm{K}$ ( $\mathrm{NK}$ ) na solução, com $\mathrm{R}^{2}$ parciais de 0,693 e 0,063 .

$\mathrm{Y}=18,420+1,983 \times 10^{-1} \times \mathrm{D}+6,789 \times 10^{-4} \times \mathrm{NK}$

$\mathrm{R}^{2}=0,756$

Onde:

$\mathrm{Y}=$ Valor SPAD;

$\mathrm{N}=$ Concentração de $\mathrm{N}$ na solução em $\mathrm{mg} \mathrm{L}^{-1}$;

$\mathrm{K}=$ Concentração de $\mathrm{K}$ na solução em $\mathrm{mg} \mathrm{L}^{-1}$;

$\mathrm{D}=$ Dias após o plantio.. 
Tabela 24. Estimativa do teor de clorofila nas folhas de $M$. arvensis L. através do valor SPAD, em função dos teores de nutrientes na solução nutritiva.

\begin{tabular}{|c|c|c|c|}
\hline \multirow{3}{*}{ Tratamentos } & \multicolumn{3}{|c|}{ Dias após o plantio } \\
\hline & 6 & 37 & 67 \\
\hline & \multicolumn{3}{|c|}{ Valor SPAD } \\
\hline Controle & $21.53 \mathrm{a}^{\mathrm{I}}$ & $27.90 \mathrm{a}$ & $36.16 a$ \\
\hline N105 & $20.58 \mathrm{a}$ & $26.00 \mathrm{a}$ & $27.99 b$ \\
\hline N420 & $23.53 b$ & $32.23 b$ & $38.70 \mathrm{a}$ \\
\hline $\mathrm{P} 15,5$ & $20.60 \mathrm{a}$ & $28.05 a$ & $34.82 \mathrm{a}$ \\
\hline P62 & $22.18 \mathrm{a}$ & $29.05 a$ & $39.38 \mathrm{a}$ \\
\hline $\mathrm{K} 117$ & $21.75 \mathrm{a}$ & $28.08 \mathrm{a}$ & $37.19 a$ \\
\hline K468 & $22.33 a$ & $25.15 b$ & $27.01 b$ \\
\hline Cal00 & $21.43 a$ & $27.57 \mathrm{a}$ & $35.89 a$ \\
\hline $\mathrm{Ca} 400$ & $21.65 \mathrm{a}$ & $28.28 \mathrm{a}$ & $30.92 a$ \\
\hline $\mathrm{Mg} 24$ & $20.25 a$ & $26.40 a$ & $30.97 a$ \\
\hline Mg96 & $21.88 \mathrm{a}$ & $27.38 \mathrm{a}$ & $32.11 \mathrm{a}$ \\
\hline
\end{tabular}

Números seguidos pelas mesmas letras, nas colunas, não diferem significativamente. Comparações entre o controle e os tratamentos do mesmo nutriente.

\subsubsection{Rendimento do óleo essencial}

O teor do óleo essencial da planta foi afetado pela variação de todos os nutrientes estudados, conforme observa-se na tabela 25. O aumento na concentração do $\mathrm{K}$, Ca e Mg, promoveram o aumento de rendimento de óleo. Mas a solução mais rica em $\mathrm{N}$ produziu as plantas mais pobres em óleo de todo o experimento. A solução mais rica em P não alterou significativamente o rendimento de óleo em relação ao controle, porém a solução com menor concentração do elemento, produziu as plantas com maior teor de óleo. 
Tuomi et al. (1991), explicaram que a concentração de metabólitos secundários, utilizados para a defesa do vegetal, tendem a ter uma concentração inversa às taxas de crescimento, por ser este o "custo da defesa". As plantas desviam metabólitos que poderiam gerar açúcares, proteínas, etc., para a produção de metabólitos secundários.

Não encontrou-se referências na literatura especializada que explicasse o motivo pelo qual as soluções mais ricas em macronutrientes catiônicos aumentaram o rendimento de óleo, enquanto que os macronutrientes aniônicos estudados ( $\mathrm{N}$ e P) o inibirem.

Um rendimento elevado por si só não tem interesse agrícola, pois plantas que produzam muito óleo, mas com baixa produção de folhas, poderão resultar em um baixo rendimento de óleo por área e por ano (peso de óleo area $^{-1}$ ano $^{-1}$ ). É o caso do tratamento P15,5; que apesar de suas plantas apresentarem um dos mais altos rendimentos de óleo (Tabela 25), a produção de folhas foi bastante reduzida (Tabela 18), resultando numa baixa produção total de óleo.

As produções melhores de óleo por vaso foram obtidas nas plantas dos tratamentos $\mathrm{K} 468$ e Ca400, que mostraram o por que a planta ter sido historicamente cultivada exclusivamente em solos recém desmatados e queimados. Os teores altos de $\mathrm{Ca}$ e $\mathrm{K}$ das cinzas remanescentes das queimadas eram as responsáveis pela manutenção das lavouras. O mesmo aplica-se ao cultivo tradicional da planta no Japão, em solos vulcânicos. 
Tabela 25. Rendimentos de óleo essencial da M. arvensis L.

\begin{tabular}{lcc}
\hline \multirow{2}{*}{ Tratamentos } & \multicolumn{2}{c}{ Óleo } \\
\cline { 2 - 3 } & $\%$ & g/vaso \\
\hline Controle & $1,17 \mathrm{a}^{\mathrm{l}}$ & $0,72 \mathrm{a}$ \\
\hline N105 & $1,02 \mathrm{a}$ & $0,41 \mathrm{~b}$ \\
N420 & $0,97 \mathrm{~b}$ & $0,79 \mathrm{a}$ \\
\hline P15,5 & $1,41 \mathrm{~b}$ & $0,65 \mathrm{a}$ \\
P62 & $1,08 \mathrm{a}$ & $0,69 \mathrm{a}$ \\
\hline K117 & $1,07 \mathrm{a}$ & $0,44 \mathrm{~b}$ \\
K468 & $1,45 \mathrm{~b}$ & $1,00 \mathrm{c}$ \\
\hline Ca100 & $1,17 \mathrm{a}$ & $0,62 \mathrm{a}$ \\
Ca400 & $1,37 \mathrm{~b}$ & $0,90 \mathrm{~b}$ \\
\hline Mg24 & $1,14 \mathrm{a}$ & $0,49 \mathrm{~b}$ \\
Mg96 & $1,52 \mathrm{~b}$ & $0,75 \mathrm{a}$ \\
\hline
\end{tabular}

Números seguidos pelas mesmas letras, nas colunas, não diferem significativamente. Comparações entre o controle e os tratamentos do mesmo nutriente.

A análise dos $\mathrm{R}^{2}$ parciais da eq. (20), mostra que as principais variáveis responsáveis pela produção de óleo essencial por vaso são o $\mathrm{KCa}$ com $\mathrm{R}^{2}$ de 0,462 ; NMg 0,194; CaMg 0,032; $\mathrm{N}^{2} 0,023 ; \mathrm{Mg}^{2} 0,066$ e K² 0,013.

$$
\begin{aligned}
\mathrm{Y}= & 3,483 \times 10^{-2}+1,307 \times 10^{-5} \times \mathrm{KC}+1,087 \times 10^{-4} \times \mathrm{NMg}-4,287 \times 10^{-5} \mathrm{CaMg}- \\
& 7,560 \times 10^{-5} \times \mathrm{N}^{2}-8,940 \times 10^{-5} \mathrm{Mg}^{2}-1,840 \times 10^{-6} \times \mathrm{K}^{2} \\
\mathrm{R}^{2}= & 0,788
\end{aligned}
$$

Onde:

$\mathrm{Y}=$ Teor de óleo essencial na massa seca da parte aérea em \%;

$\mathrm{N}=$ Concentração de $\mathrm{N}$ na solução em $\mathrm{mg} \mathrm{L}^{-1}$; 
$\mathrm{K}=$ Concentração de $\mathrm{K}$ na solução em $\mathrm{mg} \mathrm{L}^{-1}$;

$\mathrm{Ca}=$ Concentração de Ca na solução em $\mathrm{mg} \mathrm{L}^{-1}$.

$\mathrm{Mg}=$ Concentração de $\mathrm{Mg}$ na solução em $\mathrm{mg} \mathrm{L}^{-1}$.

\subsubsection{Composição do óleo essencial}

A análise dos cromatogramas (Figura 10) e a espectrometria de massas permitiram quantificar e determinar os componentes do óleo essencial da M. arvensis $\mathrm{L}$. conforme se apresenta na tabela 26. 


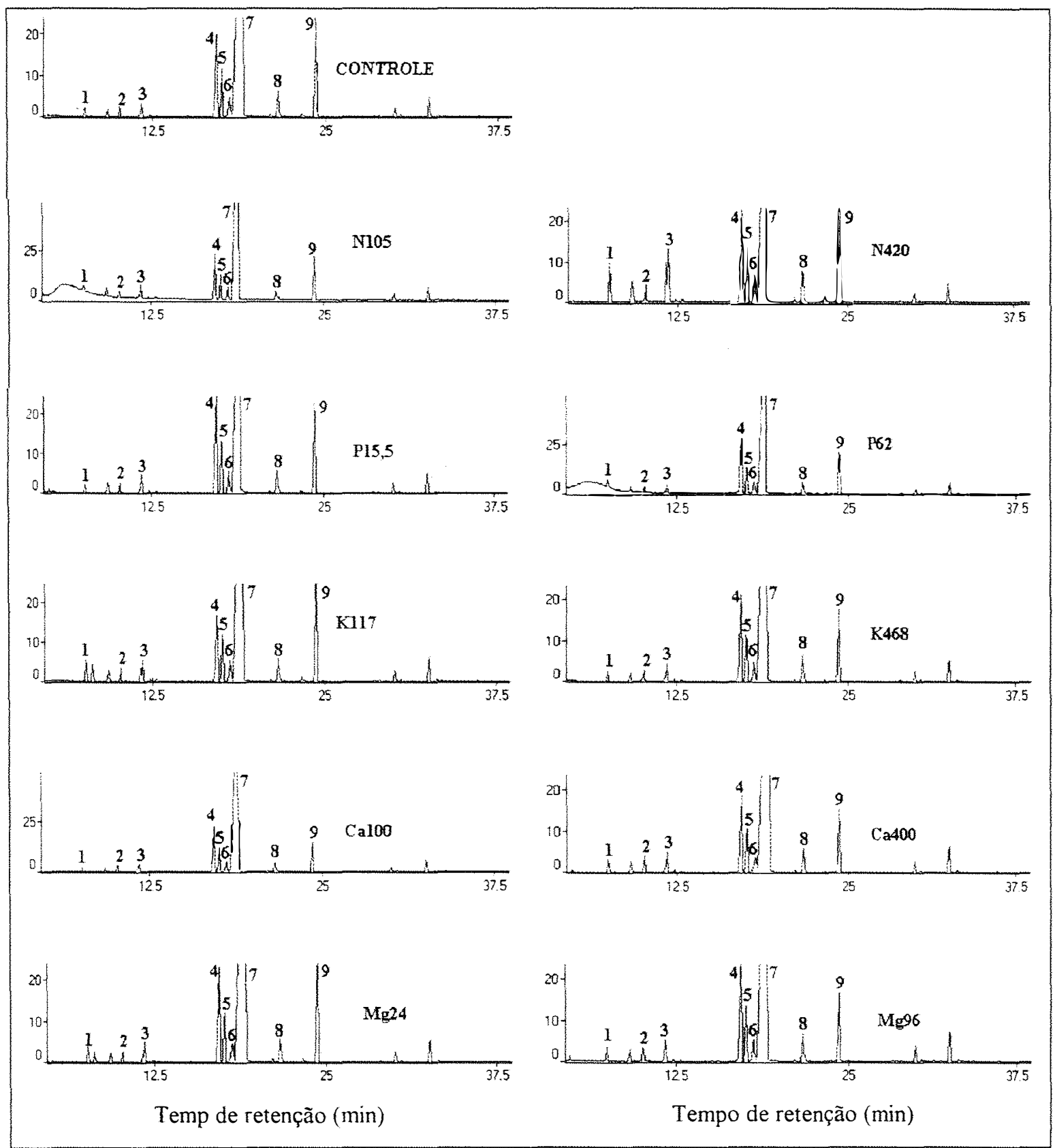

Figura 10. Cromatogramas dos óleos essenciais de $M$. arvensis L. cultivada em 11 soluções nutritivas. Os números próximos aos picos indicam as respectivas substâncias: $1=\alpha$-pineno; $2=\beta$-pineno; $3=$ limoneno; $4=$ mentona; $5=$ iso-mentona; $6=$ neomentol; $7=$ mentol; $8=$ piperitona; $9=$ mentil-acetato. 


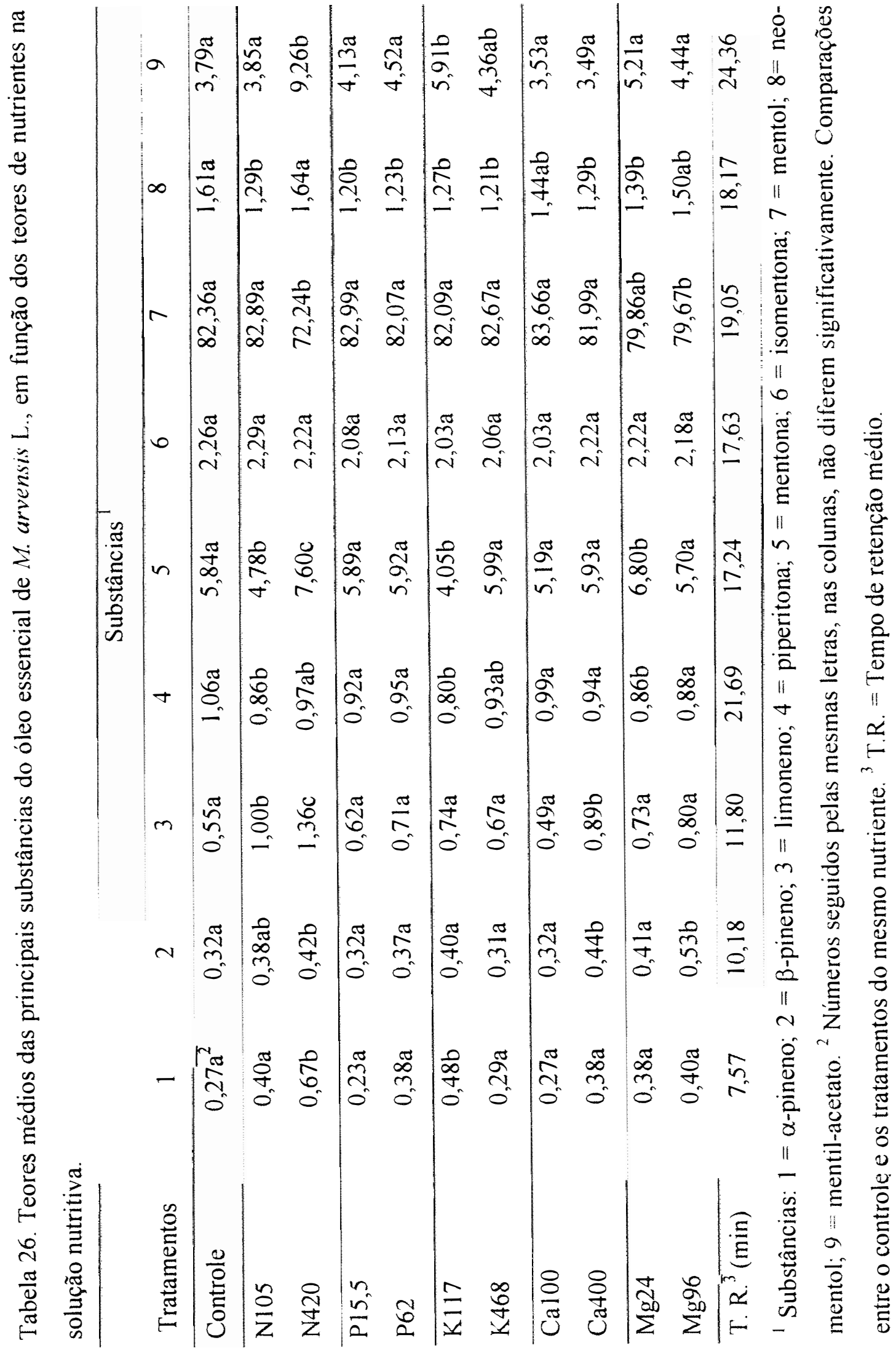


Maia (1994) relatou um aumento significativo no teor de mentol no óleo essencial de Mentha arvensis L. cultivada em solução nutritiva na qual se omitiu o P. Neste trabalho, o óleo das plantas do tratamento P15,5; a solução mais pobre no nutriente, não apresentou aumento significativo no teor de mentol, o que leva a inferir-se que a concentração critica de $\mathrm{P}$ para que ocorram aumentos expressivos do teor de mentol no óleo está entre zero e $15,5 \mathrm{mg} \mathrm{L}^{-1}$.

$O$ teor de mentol foi reduzido significativamente com o aumento da concentração de $\mathrm{N}$ e $\mathrm{Mg}$ na solução. A eq. (21), definida pelo método de incremento de $\mathrm{R}^{2}$, representa a variação no teor de mentol no óleo essencial da $M$. curvensis $\mathrm{L}$. em função da concentração do N e Mg na solução nutritiva.

$$
\begin{aligned}
\mathrm{Y} & =83,182-1,643 \times 10^{-4} \times \mathrm{N}^{2}-2,028 \times 10^{-3} \times \mathrm{Mg}^{2}+1,119 \times 10^{-3} \times \mathrm{N} \mathrm{Mg} \\
\mathrm{R}^{2} & =0,717
\end{aligned}
$$

Onde:

$\mathrm{Y}=$ Teor de mentol no óleo essencial em \%;

$\mathrm{N}=$ Concentração de $\mathrm{N}$ na solução em $\mathrm{mg} \mathrm{L}^{-1}$,

$\mathrm{Mg}=$ Concentração de $\mathrm{Mg}$ na solução em $\mathrm{mg} \mathrm{L}^{-1}$.

$\mathrm{Na}$ figura 11 apresenta-se a superfície definida pela eq. (21). Na parte superior da figura é apresentada a planimetria da superfície, onde a região mais escura delimita as concentrações de mentol superiores a $82 \%$, conseguidas com diferentes combinações de concentrações de $\mathrm{N}$ e $\mathrm{Mg}$ na solução nutritiva. Esta relação mostra que aumentos na concentração de $\mathrm{N}$, para se obter um eventual aumento da produção, deverão ser seguidos de diminuição na concentração de $\mathrm{Mg}$ de modo a se preservar um alto teor de mentol no óleo essencial. 


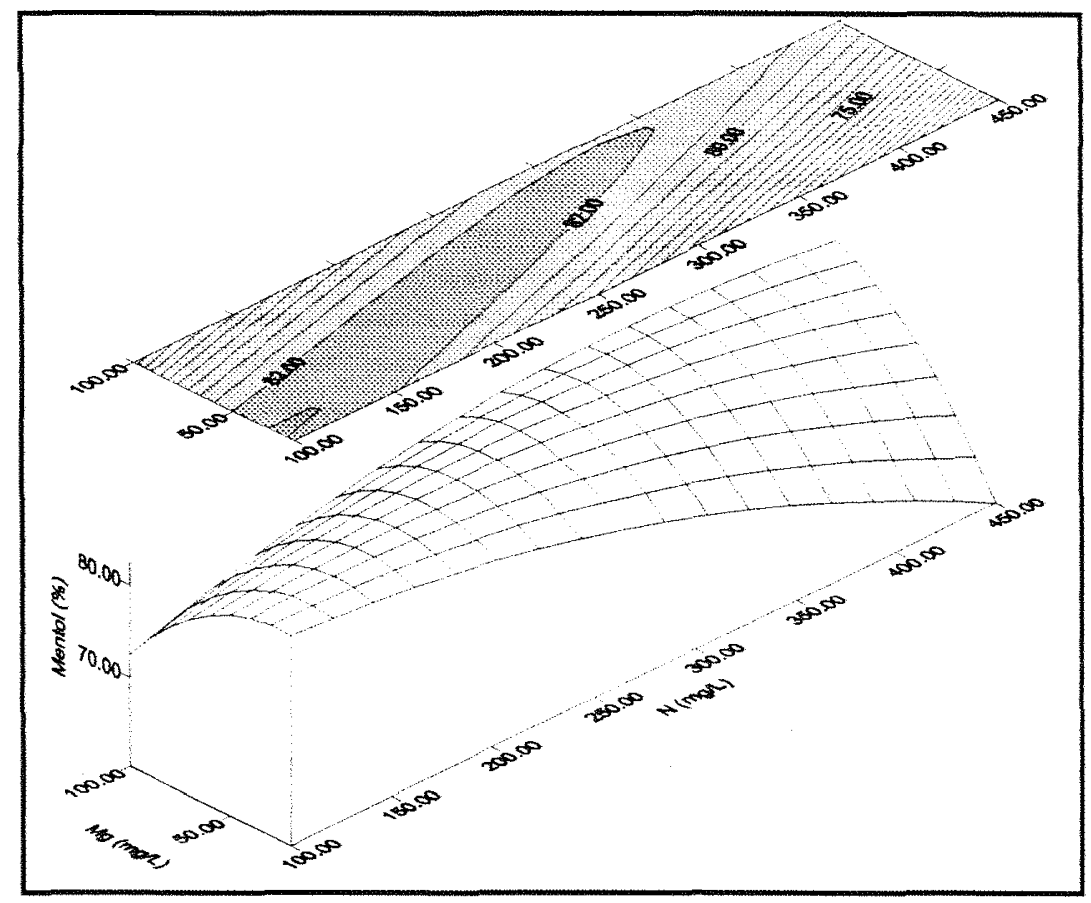

Figura 4. Superficie de resposta do teor de mentol no óleo essencial da M. arvensis L., em função da concentração de $\mathrm{N}$ e $\mathrm{Mg}$ na solução nutritiva. A parte superior da figura mostra as curvas de nível da superficie, representando os níveis de teores de mentol.

A figura 4 representa a interação $\mathrm{N}$ Mg: para baixas concentrações de $\mathrm{N}$ na solução nutritiva uma elevação no teor de $\mathrm{Mg}$ reduziu o teor de mentol no óleo. Nas altas concentrações de $\mathrm{N}$ na solução o aumento na concentração de $\mathrm{Mg}$ provoca um aumento no teor de mentol.

O tratamento onde a solução nutritiva tinha mais $N$, além de produzir menos mentol, aumentou significativamente a concentração de mentil-acetato no óleo, que é uma característica indesejável. Porém se, mesmo assim, a planta for cultivada em solução mais rica em $\mathrm{N}$ para obtenção de maior massa vegetal, a concentração de $\mathrm{Mg}$ deverá ser recalculada, substituindo-se o novo valor de $\mathrm{N}$ na eq. (21), derivando-a e igualando-a a zero, de modo a obter-se a nova concentração máxima de mentol para a nova concentração de $\mathrm{N}$ na solução. 


\subsubsection{Solução nutritiva recomendada}

Na definição de uma solução nutritiva para a M. arvensis L., buscou-se uma formulação que proporcione, não só um alto teor de óleo nas folhas, mas uma elevada produção de óleo por vaso, que será proporcional ao rendimento agrícola, isto é, a produção de óleo por área de cultivo. Quanto à qualidade, buscou-se óleos com elevado teor de mentol e baixo teor de mentil-acetato, pois teores superiores a $5 \%$ são indesejáveis.

Por esse motivo deve-se precaver de soluções muito concentradas em $\mathrm{N}$, que apesar de aumentarem significativamente a produção de folhas (Tabelas 18 e 19), têm um efeito negativo muito acentuado tanto no teor (Tabela 25), quanto na qualidade do óleo (Tabela 26). Concentrações menores do que a utilizada no tratamento controle também devem ser evitadas, por diminuirem bruscamente a produção e não afetarem a qualidade.

Caso as doses de $\mathrm{P}$ na solução utilizadas nesse trabalho não afetaram significativamente a qualidade do óleo. $\mathrm{O}$ tratamento com menor concentração de $\mathrm{P}$ na solução produziu folhas com mais óleo, mas a produção baixa de massa de parte aérea anulou o efeito positivo, devendo-se por esse motivo evitar-se concentrações menores do que $31 \mathrm{mg} \mathrm{L}^{-1}$. Esse valor deve ser utilizado como referência no preparo de soluções para $M$. arvensis L., pois concentrações maiores do que essa não melhoraram nem a qualidade nem a produtividade da planta.

O aumento significativo no teor de óleo essencial nas folhas e a produção de óleo por vaso das plantas tratadas com solução mais rica em K (K468), sem alteração significativa da qualidade, mostram que as soluções nutritivas para a espécie devem ser mais concentradas no nutriente. A concentração de $\mathrm{K}$ na solução capaz de produzir a maior produção de massa de parte aérea, calculada através da eq. (9) é $771 \mathrm{mg} \mathrm{L}^{-1}$. Porém recomenda-se somente a concentração máxima utilizada neste trabalho, evitandose a extrapolação dos resultados. Deve-se ainda atentar-se para que a condutividade elétrica da solução preparada não seja mais elevada do que a obtida no tratamento K468 
(Tabela 17). Doses menores do que a do tratamento controle devem ser evitadas pois podem reduzir drasticamente a produção da parte aérea (Tabela 18) e aumentar o teor de mentil-acetato no óleo (Tabela 26).

A solução mais concentrada em $\mathrm{Ca}$, apesar de não alterar a produção da parte aérea, produziu plantas com mais raízes (Tabela 18), o que facilita a absorção de outros nutrientes, além de ter aumentado significativamente o teor de óleo nas folhas (Tabela 25), sem alterações importantes na qualidade do óleo (Tabela 26). A concentração maior de $\beta$-pineno e limoneno no óleo das plantas do tratamento $\mathrm{Ca} 400$, indicam uma imaturidade da planta que ainda não converteu as moléculas em mentol, conforme representado na figura 4, uma vez que aquelas duas moléculas são precursoras da última. Deve-se evitar soluções com baixos teores de $\mathrm{Ca}$, pois as plantas ficam susceptíveis ao ataque da bactéria Pseudomonas cichorii (Maia et al., 1996).

Com base nos resultados obtidos nesse trabalho, deve-se manter a concentração de $\mathrm{Mg}$ na solução nutritiva semelhante à do tratamento controle, pois a concentração menor produziu menos massa de parte aérea, raízes e óleo essencial, o qual apresentou teor de mentil-acetato elevado. O aumento da concentração do nutriente na solução, apesar de ter aumentado o teor de óleo nas folhas (Tabela 25), diminuiu a produção de parte aérea (Tabela 18) e afetou significativamente a qualidade do óleo essencial, devido ao menor teor de mentol. Por não ter sido estudado o efeito da concentração de $\mathrm{S}$, devese adotar a concentração definida por Sarruge (1975). Na tabela 27 mostra-se a composição da melhor solução nutritiva para o cultivo de $M$. arvensis L. 
Tabela 27. Composição da solução nutritiva para o cultivo de M. arvensis L.

\begin{tabular}{lc}
\hline Nutrientes & Concentração $\left(\mathrm{mg} \mathrm{L}^{-1}\right)$ \\
\cline { 2 - 2 } $\mathrm{N}$ & 210 \\
$\mathrm{P}$ & 31 \\
$\mathrm{~K}$ & 468 \\
$\mathrm{Ca}$ & 400 \\
$\mathrm{Mg}$ & 48 \\
$\mathrm{~S}$ & 64 \\
\hline Micronutrientes & - \\
\hline Micronutrientes nas concentrações definidas na tabela 2 do item 3.5.
\end{tabular}




\section{CONCLUSÕES}

Os resultados deste trabalho permitem apresentar as seguintes conclusões:

- O sistema automático de irrigação com solução nutritiva foi melhor que o sistema convencional.

- A frequeencia de irrigação com solução nutritiva foi determinante da maior produção vegetal e da qualidade do óleo essencial da $M$. crispa.

- As concentrações de nutrientes da solução nutritiva no cultivo da $M$. crispa e M. arvensis L., alteraram a produção vegetal das duas espécies.

- A composição do óleo essencial da M. arvensis L. foi alterada pelas concentrações de N, P, K, Ca e Mg na solução.

- A concentração de mentol no óleo essencial da M. arvensis L. foi alterada em função da concentração de $\mathrm{N}$ e $\mathrm{Mg}$ na solução.

- Foi possível aumentar a produção de massa vegetal com soluções mais concentradas em $\mathrm{N}$.

- Foi possível se aumentar o rendimento de óleo essencial de M. arvensis L. com soluções nutritivas mais concentradas em $\mathrm{K}$ e Ca.

- As condições de nutrição mineral da planta alteraram a produção dos metabólitos secundários no óleo essencial.

- Novos experimentos devem ser desenvolvidos, para se definir as concentrações máximas adequadas de $\mathrm{K}$ e Ca na solução nutritiva para o cultivo de $M$. arvensis e de $\mathrm{N}$ para M. crispa. 


\section{REFERÊNCIAS BIBLIOGRÁFICAS}

AGREN, G.I. Theory of growth of plant derived from the nitrogen productivity concept. Physiologia Plantarum, v.64, p. 17-28, 1985.

AGREN, G.I; INGRESTAD, T. Root: shoot ratio as a balance between nitrogen productivity and photosyntesis. Plant, Cell and Environment, v.10, p.579-586, 1987.

ALMEIDA, E.R. Plantas medicinais. São Paulo: Hemus Editora, 1993.247p.

ALMIRALL, M.; MONTAÑA, J.; ESCRIBANO, E.; OBACH, R.; BERROZPE, J.D. Effect of d-limonene, alpha-pinene and cineole on in vitro transdermal human skin penetration of chlorpromazine and haloperidol. Arzneimittelforschung, v.46, p.676-680, 1996.

BATAGLIA, O.C. Micronutrientes: disponibilidade e interações. In: REUNIÃO BRASILEIRA DE FERTILIDADE DO SOLO, 17, Londrina, 1988. ENXOFRE E MICRONUTRIENTES NA AGRICULTURA BRASILEIRA; anais. Londrina: EMBRAPA / IAPAR / SBCS, 1988. p. 121-132. 
BATAGLIA, O.C. Avaliação do estado nutricional da planta e disponibilidade no solo: análise química de plantas. In: FERREIRA, M.E.; DA CRUZ, M.C. (Ed.) Micronutrientes na agricultura. Piracicaba: Potafos - CNPq, 1991. Cap.6, p.289-308.

BELL, E.A. The physiological role(s) of secondary (natural) products. In: Conn, E.E. The biochemistry of plants. New York: Academic Press, 1981. vol.7, cap. 1, p.1-20.

BLACKMER, T.M.; SCHEPERS, J.S.; VIGIL, M.F. Chlorophyll meter readings in corn as affected by plant spacing. Communications in Soil Science and Plant Analysis, v.24, p.2507-2516, 1993.

BOHE, L.R.; MANCINI, P.M.E.; GIUSSANI, C.D.; ITURRASPE, J.B. Menthol a partir de verbenone, verbenol et citronellal. Essenze Derivati Agrumari, v.53, p.478$485,1980$.

BORKERT, C.M. Micronutrientes no solo - Manganês. In: FERREIRA, M.E.; DA CRUZ, M.C. (Ed.) Micronutrientes na agricultura. Piracicaba: Potafos - CNPq, 1991. Cap.5, p.173-190. 1983. 48p. (Boletim Técnico, 78).

BRILHO, R.C. Menta. Campinas: Secretaria da Agricultura do Estado de São Paulo, 1969. 34p. (CATI. Boletim Técnico - SCR - 44)

BRODERICK, J.J. Mint. Perfumer \& Flavorist, v. 18, p.51-52, 1993.

CALDAS, L.S.; HARIDASAN, P.; FERREIRA, M.E. Meios nutritivos. In: TORRES, A.C.; CALDAS, L.S. Técnicas e aplicações da cultura de tecidos de plantas. Brasília: EMBRAPA/CNPH, 1990. Cap. 2, p.37-70. 
CAMPBELL, R.J.; MOBLEY, K.N.; MARINI, R.P.; PFEIFFER, D.G. Growing conditions alter the relationship between SPAD-501 values and apple leaf chlorophyll. Hort Science, v.25, p.330-331, 1990.

CARMELLO, Q.A.C. Qualidade da água e manejo da solução hidropônica. In: ENCONTRO DE HIDROPONIA, 2, Campinas, 1997. II ENCONTRO DE HIDROPONIA, resumos. Campinas: Faculdade de Engenharia Agrícola UNICAMP, 1997, p.49-69.

CARMELLO, Q.A.C.; ROSSI, F. Hidroponia: solução nutritiva. Viçosa: Centro de Produções Técnicas, 1997. 56p. (CPT.Manual Tecnico, 111)

CHARLES, D.J.; JOLY, R.J.; SIMON, J.E. Effects of osmotic stress on the essential oil content and composition of peppermint. Phytochemistry, v.29, p.2837-2840, 1990.

CHARLWOOD, B.V.; CHARLWOOD, K.A. Monoterpenoids. In: CHARLWOOD, B.V.; BANTHORPE, D.V.. Terpenoids. London: Academic Press, 1991. cap.2, p. 43-98. (Methods in Plant Biochemistry).

CHIRIS, E.A. The cultivation of mints. Parfums de France, v. 19, p. 151-159, 1925.

CLARK, G.S. Menthol. Perfumer \& Flavorist, v. 13, p.37-46, 1988.

CLARK, G.S. Mentone. Perfumer \& Flavorist, v. 19, p.41-45, 1994.

COLWELL, J.D. Estimating fertilizer requirements: a quantitative approach. Wallingford: CAB International, 1994. 262p. 
CORREA, M.P. Dicionário das plantas úteis do Brasil. Rio de Janeiro: Ministério da Agricultura - Instituto Brasileiro de Desenvolvimento Florestal, 1969. 4v.

COSTA, A.F. Métodos que isolam as essências por destilação aquosa. ln: COSTA, A.F. Farmacognosia. 3.ed. Lisboa: Fundação Calouste Gulbenkian, 1975. cap.3, p.436-440.

CROCOMO, O.J.; AQUARONE, E. \& GOTTLIEB, O.R. Biosynthesis of secondary products in vitro. In: Plant and Tissue in Agriculture Methods and Aplication in Agriculture. Calgary: T. A. Thorpe, 1981. pp 359-372.

CZEPAK, M.P. Produção de óleo bruto e mentol cristalizável em oito freqüências de colheita da menta (Mentha arvensis L.). Piracicaba, 1995. 81 p. Dissertação (Mestrado) - Escola Superior de Agricultura "Luiz de Queiroz", Universidade de São Paulo.

DECHEN, A.R.; HAAG, H.P.; CARMELLO, Q.A.C. Micronutrientes na planta: mecanismos de absorção e de translocação de micronutrientes. In: FERREIRA, M.E.; DA CRUZ, M.C. (Ed.) Micronutrientes na agricultura. Piracicaba: Potafos - CNPq, 1991. Cap.4, p.65-110.

DECHEN, A.R.; HAAG, H.P.; CARMELLO, Q.A.C. Avaliação do estado nutricional da planta e disponibilidade no solo: diagnose visual. In: FERREIRA, M.E.; DA CRUZ, M.C. (Ed.) Micronutrientes na agricultura. Piracicaba: Potafos - CNPq, 1991. Cap.6, p.273-288.

DE LORENZI, F.L. M. Avaliação terapêutica do penetro inalante em pacientes portadores de afecções das vias aéreas. A Folha Médica, v. 112, p.201-204, 1996. 
DENYS, J.C.; JOLY, R.J.; SIMON, J. Effects of osmotic stress on the essential oil content and composition of peppermint. Phytochemistry, v.29, p.2837-2840, 1990.

DONALÍSIO, M.G.R.; PINTO, A.J.D.; SOUZA, C.J· Variação na resistência à ferrugem e na composição do óleo essencial de dois clones de menta. Bragantia, v.4, p.541$547,1985$.

DUGGER, W.M. Boron in plant metabolism. In: LÄUCHLl, A.; BIELESKI, R.L. Inorganic plant nutrition. Berlin: Springer-Verlag, 1983. cap.5.2, p.621-650.

DUHAN, S.P.S.; SINGH, V.P.; BHATTACHARYA, A.K.; HUSAIN, A. Response of japanese mint (Mentha arvensis L.) to different irrigation schedules. In: INTERNATIONALL CONGRESS OF ESSENTIAL OILS, 7. Kyoto, 1977. Proceeding. Kyoto, Japan Flavor and Fragance Manufactores`Association, 1977. p. $143-5$.

EDWARDS, P.J.; WRATTEN, S.D. Substâncias secundárias das plantas como toxinas. In: EDWARDS, P.J.; WRATTEN, S.D. Ecologia das interações entre insetos e plantas. São Paulo: Editora Pedagógica e Universal, 1981. cap.3, p.19-25:

FAROOQI, A.H.A. \& MISRA, A. Effect of micronutrients on oil content and plant growth in Mentha arvensis L. var. piperascens Mal. Indian Journal of Plant Physiology, v.26, p.230- 233, 1983.

FERREIRA, M.E.; CRUZ, M.C.P. Micronutrientes no solo: Cobre. In: FERREIRA, M.E.; DA CRUZ, M.C. (Ed.) Micronutrientes na agricultura. Piracicaba: Potafos - CNPq, 1991. Cap.5, p.131-157. 
FINNEMORE, H. The essential oils. London: Ernest Benn, 1926. 880p.

FISCHER, G.; HECHT-BUCHHOLZ, C. The influence of boron deficiency on glandular scale development and structure in Mentha piperita. Planta Medica, v.5, p.371-377, 1985 .

GARCIA, E.S.; SILVA, A.C.P.;GILBERT, B.; CORRÊA, C.B.V.; CAVALHEIRO, M.V.S.; SANTOS, R.R.; TOMASSINI, T. Fitoterápicos. In: WORKSHOP BIODIVERSIDADE: PERSPECTIVAS E OPORTUNIDADES TECNOLÓGICAS, Campinas, 1996. Workshop: Biodiversidade: Perspectivas e Oportunidades Tecnológicas. Campinas: Fundação Tropical de Pesquisas e Tecnologia "André Tosello", 1996. p.1-17.

GOMES, F.P. Curso de estatística experimental. Piracicaba, Livraria Nobel, 1981. $430 \mathrm{p}$.

GREENHALG, P. The markets for mint oils and menthol. London: Tropical Products Institute, $1979,171 \mathrm{p}$.

GUENTHER, E. The essential oils. New York: D. van Nostrand, 1949. 3v.: Individual essential oils of the plant families Rutaceae and Labiatae, 777p.

HAAG, H.P.; CARMELLO, Q. A.C. Nutrição mineral de leguminosas tropicais. VIII. Sintomas de desnutriçào de macronutrientes e boro em Sesbania sp. Anais da Escola Superior deAagricultura “Luiz de Queiroz", v.46, p.53-60, 1989. 
JONES, J.B.; WOLF, B.; MILLS, H. A. Plant analysis handbook - A practical sampling preparation, analysis, and interpretation guide. Athens: Micro-Macro Publishing, 1991. 213p.

KABATA-PENDIAS,A.; PENDIAS, H. Trace elements in soils and plants. 3. ed. Boca Raton, CRC Press, 1985. 315p.

KABAYASHI, D.; KAWABATA, S.; SUGIBAYASHI, K.; MORIMOTO, Y.; KMURA, M. In vitro / in vivo difference in enhanced skin permeation of nicardipine hydrochloride by the I-menthol-ethanol system. Skin Pharmacology, v.9, p.130136, 1996.

KOTHARI, S.K.; SINGH, V.; SHINGH, K. Effect of rates and methods of phosphorus application on herb and oil yields and nutrient concentrations in japanese mint (Mentha arvensis L.). Journal of Agricultural Science, v. 108, p.691-693, 1987.

KRISCHIK, V.A. Specific or generalized plant defense: reciprocal interactions between herbivores and pathogens. In: BARBOSA, P.; KRISCHIK, V. A.; JONES, C.G. Microbial mediation of plant-herbivore interactions. New York: Jon Wiley, 1991, cap.11. p.309-340.

KRUG, F.J.; ROSIAS, M.F.G.; HERNANDES, W.; OLIVEIRA, E.; OLIVEIRA, P.V., LIMA, E.C.; ARRUDA, M.A.Z.; FERREIRA, J.R. Laboratory Program. In: WORKSHOP ON METHODS OF SAMPLE DECOMPOSITION, 1, Piracicaba, 1996. Aulas práticas. Piracicaba: CENA-USP, 1996. p.1-16.

LEVINS. A.S.; MOONEY, H.A.; FIELD, C. The dependence of plant root: shoot ratios on internal nitrogen concentration. Annal of Botany Company. v.64, p.71-75, 1989. 
LEWINSOHN, E. Molecular biology for the improvement of medicinal and aromatic plants. In: INTERNATIONAL SYMPOSIUM ON MEDICINAL AND AROMATIC PLANTS, Atla, 1995. Acta Horticulturae - 426. Leiden: ISHS, 1996. p.443-466.

LINDROTH, R.L. Differential toxicity of plant allelochemicals to insects: Roles of enzymatic detoxication systems. In: BERNAYS, E.A. Insect-plant interactions. Boca Raton: CRC, 1991. vol.3. cap.1, p.1-33.

LITTLE, M.T.; HILLS, F.J. Statistical methods in agricultural research. Davis: University of California, 1972. 242p.

LOOMIS, W.D.; CROTEAU, R. Biochemistry of terpenoids: a comprehensive treatise. In: STUMPF, P.K.; CONN, E.E. The biochemistry of plants. New York: Academic Press, 1980. vol.4, cap.13, p.363-418.

LOPES, A.S.; CARVALHO, J.G. Micronutrientes: critérios de diagnose para solo e planta, correção de defici6encias e excessos. In: REUNIÃO BRASILEIRA DE FERTILIDADE DO SOLO, 17, Londrina, 1988. ENXOFRE E MICRONUTRIENTES NA AGRICULTURA BRASILEIRA; anais. Londrina: EMBRAPA / IAPAR / SBCS, 1988. p.133-178.

LUCKNER, M. Secondary metabolism in plants and animals. New York: Academic Press, 1972. 404p. 
MAIA, N.B. Nutrição mineral, crescimento e qualidade do óleo essencial da menta (Mentha arvensis L.) cultivada em solução nutritiva. Piracicaba, 1994. 69p. Dissertação (Mestrado) - Escola Superior de Agricultura "Luiz de Queiroz", Universidade de São Paulo.

MAIA, N.B.; MALAVOLTA, V.A.; CARVALHO, R.V.; FANCELLI, M.I; CARMELLO, Q.A.C. Ocorrência de Pseudomonas cichorii em Menta arvensis L. Summa Phytopathologica, v.22, p. 185-188, 1996.

MAIRAPETYAN, S.K. Efficiency and perspectives of growing valuable essential oilbearing plants in open-air hydroponics in armenia. ISOSC proceedings, 1984. $107 p$.

MALAVOLTA, E. Elementos de nutrição mineral de plantas. São Paulo: Ed. Agronômica Ceres, 1980. 251p.

MALLOWS, C.L. Some concepts on Cp. Technometrics, v.15,p.661-675, 1973.

MANGEL, K.; KIRKBY, E.A. Principles of plant nutrition. 3.ed. Bern: International Potash Institute, 1982. 655p.

MARSCHNER, H. Mineral nutrition of higher plants. 2.ed. Londom: Academic Press, 1995. 889p.

MERCK The Merck index. Pittsburgh: Merck \& CO., 1968. 1713p.

MISRA, A. \& SHARMA, S. Critical concentration of Iron in relation to essential oil yield and quality parameters of japanese mint. Soil Science and Plant Nutrition, v.37, p.185-192, $1991 \mathrm{a}$. 
MISRA, A. \& SHARMA, S. Critical Zn concentration for essential oil yield and menthol concentration of japanese mint. Fertilizer Research, v.28, p.261-265, $1991 b$.

MISRA, A. Zinc nutrition related to critical deficiency and toxicity levels for japonese mint. Journal of Herbs, Spices \& Medicinal Plants, v.3, p.37-43, 1995.

McLAFFERTY, D.B.; STAUFFER, D.B. The Wiley/NBS Registry of mass spectral data. vol 1-7, Wiley, New York, 1989.

MROGINSKI, L.A.; ROCA, W.M. Estabelecimento de cultivos de tejidos vegetales in vitro. In: ROCA, W.M.; MROGINSKI, L.A. Cultivo de tejidos en la agricultura.: Fundamentos y aplicaciones. Cali: CIAT, 1991. cap.2, p.19-40.

MURASHIGE, T.; SKOOG, F. A revised medium for rapid growth and bio assay with tissue cultures. Physiologia Plantarum. v.15, p.473-497, 1962.

MURRAY, M.J.; FAAS, W.; MARBLE, P. Chemicalcomposition of Mentha arvensis var. piperascens and four hybrids with Mentha crispa harvested at different times in Indiana and Michigan. Crop Science, v. 12, p.742-745, 1972.

NAIR, A.K.; SUBRAMANYAM, K.; VERMA, B.S.; SINGH, D.V. Effect of level of fertility, iron and zinc on herbage yield and menthol content of japanese mint (Mentha arvensis subsp. haplocalyx var. piperascens). Indian Journal of Agricultural Sciences, v.61, p.599-600, 1991. 
NEEDHAM, P. The occurrence and treatment of mineral disorders in the field. In: ROBINSON, J.B.D.. Diagnosis of mineral disorders in plants: principles. London: Crown, 1983, cap.4, p.137-170.

PARÉ, P.W.; TUMLINSON, J.H. De novo biosynthesis of volatiles induced by insect herbivory in cotton plants. Plant Physiology, v.114, p.1161-1167, 1997.

PARSONS, R. Statistical analysis: a decision-making approach. New York: Harper \& Row, 1978. 791p.

PENG, S.; LAZA, M.R.C.; GARCÍA, F.V.; CASSMAN, K.G. Chlorophyll meter estimates leaf area-based nitrogen concentration of rice. Communication in Soil Science and Plant Analysis. v.26, p.927-935, 1995.

PIEKIELEK, W.P.; FOX, R.H.; TOTH, J.D. Use of a chlorophyll meter at the early dent stage of corn to evaluete nitrogen sufficiency. Agronomy Journal, v.87, p.403408, 1995.

RAIJ, B. van. Avaliação da fertilidade do solo. Piracicaba: Instituto Internacional da Potassa, 1981. 142p.

RAM, M.; YADAV, R.L.; CHATTERJEE, B.N.; SINGH, D.V. Relative efficacy of nitrogen-carriers at different rates and times of application on growth and yield of japanese mint (Mentha arvensis). Indian Journal of Agricultural Sciences, v.59, p.236-241, Apr. 1989.

REISENAUER, H.M. The interactions of Manganese and Iron. In: MANTHEY, J.A.; CROWLEY, D.E.; LUSTER, D.G. Biochemistry of metal micronutrients in the rhizosphere. Boca Raton: Lewis Publishers, 1994. Cap.11, p.147-164. 
RESH, H.M. Hydroponic food production. Santa Barbara: Woodbridge Press Publishing Company, 1986. 318p.

RICKLEFS, R.E. Biologicals factors in the enviromment. In: RICKLEFS, R.E. Ecology. New York: W.H. Freeman, 1990. cap.8, p.117-139:.

SAJWAN, K.S.; LINDSAY, W.L. Effects of redox on zinc deficiency in paddy rice. Soil Science Society of America Journal. v.50, p. 1264-9, 1986.

SANTANA, C.F.; ALMEIDA, E.R., SANTOS, E.R.Dos, SOUZA, I.A. Action of Mentha crispa hydroethanolic extract in patients bearing intestinal protozoam. Fitoterapia, v.63, p.409-410, 1992.

SANTOS, A.R. dos Respostas de braquiária decumbens a doses de nitrogênio e de enxofre. Piracicaba, 1997. 112p. Tese (Doutorado) - Escola Superior de Agricultura "Luiz de Queiroz", Universidade de São Paulo.

SANTOS, S.R. Menta. In: FURLANI, A.M.C. \& VIEGAS, G.P., ed. O melhoramento genético de plantas no Instituto Agronômico. 19.ed. Campinas, Instituto Agronômico, 1993. v. 1, cap. 9, p.355-62.

SARAIVA, P.A.P.; AIZENSTEIN, M.L.; ZANINI, A.C. Aparelho respiratório. In: ZANINI, A.C.; OGA, S. Farmacologia aplicada. 5.ed. São Paulo: Atheneu, 1994. cap.72, p.589-599.

SARRUGE, J.R.; Soluções nutritivas. Summa Phytopathologica, v.1, p.231-233, 1975. 
SARRUGE, J.R. \& HAAG, H.P. Análises químicas em plantas. Piracicaba, USP/ESALQ, 1974. 55p.

SAS INSTITUTE CORPORATION. Propriety software release 6.08. Cary, 1989.

SCHILCHER, H. Quality requirements and quality standards for medicinal, aromatic and spices plants. In: INTERNATIONAL SYMPOSIUM ON HEAVY METALS AND PESTICIDE RESIDUES IN MEDICINAL, AROMATIC AND SPICE PLANTS, Novi Sad, 1985. Acta horticulturae, Wageninge: ISHS, 1989. v.249, p. $33-44$

SHUGAR, G.J.; BALLINGER, J.T. Destillation and evaporation. In: SHUGAR, G.J.; BALLINGER, J.T. Chemical technicians'ready reference handbook. New York: McGraw Hill, 1990. cap.21, p.473-532:

SINGH, A.K.; DIKSHIT, A.; DIXIT, S.N. Fungitoxic properties of essential oil of Mentha arvensis var. piperascens. Perfumer \& Flavorist, v.8, p.55-58, 1983.

SINGH, J.N. \& SINGH, D.P. Studies in the mineral nutrition of japanese mint; I influence of phosphorus deficiency on nitrogen metabolism. Plant and Soil, v.28, p.363-371, 1968.

SINGH, S.P.; CHAND, L.; NEGRI, S.; SINGH, A.K. Antibacterial and antifungal activities of Mentha arvensis essential oil. Fitoterapia, v.63, p.76-78, 1992. 
SINGH, V.P. \& SINGH, D.V. Accumulation pattern of chemical constituents in mentha species with advance of crop age and nitrogen level. In: INTERNATIONAL SYMPOSIUM ON MEDICINAL AROMATIC AND SPICES PLANTS, 5. Darjeeling, 1985. Acta Horticulturae. Wageningen: ISHS, 1989. v.188a, p.187189.

SINHA, N.C. \& SINGH, J.N. Studies in the mineral nutrition of japanese mint; II. Influence of potassium deficiency and seasonal variations on nitrogen metabolism, respiration rate and essential oil content. Plant and Soil, v.79, p.51-59, 1984.

SOUZA, E.C.A.; FERREIRA, M.E. Zinco - Manganês. In: FERREIRA, M.E.; DA CRUZ, M.C. (Ed.) Micronutrientes na agricultura. Piracicaba: Potafos - CNPq, 1991. Cap.5, p.219-242.

SUBRAHMANYAM, K.; NAIR, A.K.; CHATTOPADHYAY, A.; SINGH, D. Effect of Zinc on yield, quality and nutrient composition of japanese mint and avaibility of nutrients in soil. Journal of the Indian Society Soil Science, v.39, p.399-401, 1991.

TISDALE, S.L.; NELSON, W.L.; BEATON, J.D.; HAVLIN, J.L. Soil fertility and fertilizers. 5 ed.New York: Macmillan Publishing Company, 1993. 634p.

TROUGHT, C.T.; DREW, M.C. The development of water logging damage in wheat seedlings (Triticun aestivum L.) Plant and Soil. v.54, p.77-94, 1980. 
TUOMI, J.; FAGERSTRÖM, T.; NIEMELÄ, P. Carbon allocation, phenotypic plasticity and induced defences. In: TALLAMY, D.W.; RAUPP, M.J. Phyto chemical induction by herbivores. New York: John Wiley, 1991. cap.4, p.85104.

VICKERY, M.L.; VICKERY, B. Secondary plant metabolism. Hong Kong: Macmillan Press, 1981.335p.

ZIMENT, I. Farmacologia e terapêutica respiratória. Trad. de W.L. de Oliveira. Rio de Janeiro: Interamericana Ed., 1982. 500p. 